\title{
Depleted Uranium Disposal Options Evaluation
}

\author{
T. J. Hertzler
}

D. D. Nishimoto

M. D. Otis

Published May 1994

\section{Waste Management Technology Division Science Applications International Corporation 545 Shoup Ave. Idaho Falls, Idaho 83405-0697}

Prepared for EG\&G Idaho, Inc. and the U.S. Department of Energy

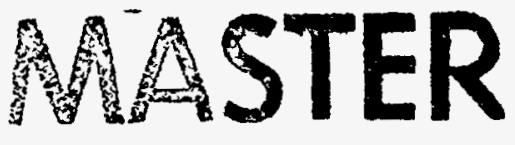

Office of Environmental Restoration and Waste Management under DOE Idaho Operations Office Contract DE-AC07-76ID01570 


\section{DISCLAIMER}

This report was prepared as an account of work sponsored by an agency of the United States Government. Neither the United States Government nor any agency thereof, nor any of their employees, make any warranty, express or implied, or assumes any legal liability or responsibility for the accuracy, completeness, or usefulness of any information, apparatus, product, or process disclosed, or represents that its use would not infringe privately owned rights. Reference herein to any specific commercial product, process, or service by trade name, trademark, manufacturer, or otherwise does not necessarily constitute or imply its endorsement, recommendation, or favoring by the United States Government or any agency thereof. The views and opinions of authors expressed herein do not necessarily state or reflect those of the United States Government or any agency thereof. 


\section{DISCLAIMER}

Portions of this document may be illegible in electronic image products. Images are produced from the best available original document. 


\section{Depleted Uranium Disposal Options Evaluation}

EGG-MS-11297

Prepared by:

Timothy J. Hertzler, Project Engineer

Date

Science Applications International Corporation

Srequar D. Nishemoto

Douglas D. Nishimoto, Senior Project Engineer

Science Applications International Corporation

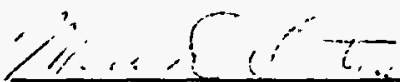

Mark D. Otis, Certified Health Physicist

Science Applications International Corporation

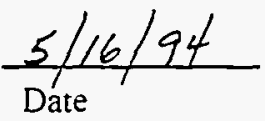

Reviewed by:

Heico H. Eence

Milo M. Larsen, Division Manager

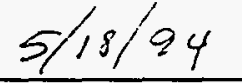

Science Applications International Corporation

Date

Reviewed and Approved by:

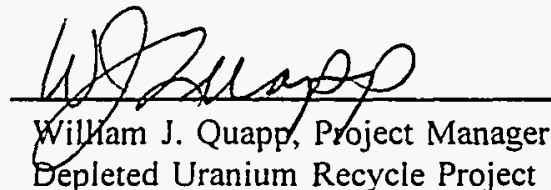




\begin{abstract}
This report describes the results of a study evaluating the disposal of the Department of Energy's (DOE) depleted uranium (DU) reserves. This report is in no way implying that these DU reserves are a "waste," but is intended to provide baseline data for comparison with other management options. The evaluation includes: identification of radiological and chemical hazards of DU, a qualitative assessment of various chemical forms of DU to establish the preferred reference form for disposal, review of the regulatory requirements applicable to the management and disposal of DU, discussion of DOE and commercial disposal sites potentially available for DU disposal, and estimation of all appropriate disposal costs.
\end{abstract}

The results of this evaluation document that:

- DU disposal is only technically and economically feasible at the Nevada Test Site (NTS) and the Hanford Site.

- The preferred chemical form, referenced in this study, for DU disposal is uranium oxide (i.e., $\mathrm{U}_{3} \mathrm{O}_{8}$ ).

- The DU reserves are "source material" solely regulated under the Atomic Energy Act (AEA) of 1954, as amended.

- The cost to dispose of the current inventory (June 1992) of $\mathrm{UF}_{6}$ as $\mathrm{U}_{3} \mathrm{O}_{8}$ ranges from a low of $\$ 3.4$ billion $(\$ 9.50 / \mathrm{kgU}$ ) to a high of $\$ 10.9$ billion ( $\$ 30.19 / \mathrm{kgU}$ ).

- The cost to dispose of the $\mathrm{UF}_{6}$ as uranium metal is estimated to be more expensive than $\mathrm{U}_{3} \mathrm{O}_{8}$ disposal due to higher conversion costs.

- The greatest potential for reduction in disposal costs is in the development of new conversion technologies. 


\section{EXECUTIVE SUMMARY}

The Department of Energy (DOE), Office of Environmental Restoration and Waste Management, has chartered a study to evaluate alternative management strategies for depleted uranium (DU) currently stored as strategic reserves throughout the DOE complex. One potential management strategy, and the focus of this study, is disposal of the DU at a DOE or commercial disposal facility. This report is in no way declaring these DU reserves a "waste," but is intended to provide baseline data for comparison with other management options for DU.

Naturally occurring uranium consists primarily of the stable isotope U-238, with only about $0.7 \%$ being the fissile isotope U-235. The U.S. government has been enriching uranium since the 1940s, initially for military needs and later for fuel for commercial nuclear power plants. The enrichment process involves separating a feed stream of natural uranium hexafluoride $\left(\mathrm{UF}_{6}\right)$ into a U-235 enriched product stream and a much larger by-product stream depleted in U-235. The depleted stream (i.e., DU) is typically $99.80 \%$ U-238 and $0.02 \%$ fissile U-235. Virtually all of the DU tails from the enrichment plants have been saved as a resource in the form of solid $\mathrm{UF}_{6}$. DOE currently has a DU inventory of about 402,000 metric tons of uranium (MTU), the majority of which is located at three gaseous diffusion plants (GDPs) in Paducah. KY. Piketon, OH, and Oak Ridge, TN. As of June 1992, the GDPs were storing 361,000 MTU, accounting for about $89.8 \%$ of DOE's total inventory.

The primary objective of this report is to provide cost estimates for a baseline management option, which DOE may compare with the costs of alternative uses of DU. The conclusions drawn are as follows:

Of the two disposal site options identified and evaluated, viz. DOE and commercial sites, study findings indicate that only disposal at existing DOE sites is feasible. Current regulations at the Nevada Test Site (NTS) and the Hanford Site, both Federally-owned and contractor-operated, allow disposal of the DU as long as it meets the specific site waste acceptance criteria (WAC). WAC, and/or disposal costs, effectively eliminate the potential for disposing of the DU at commercial disposal sites. Site-specific criteria and descriptions are given in Chapter 5 of this report.

- Because of the reactive nature of $\mathrm{UF}_{6}$, the radiological and chemical hazards of various DU forms were investigated to determine a suitable disposal form. Based upon information presented in Chapter 3, the uranium oxide $\mathrm{U}_{3} \mathrm{O}_{8}$ has been used as the preferred reference form for disposal in this study. However, for comparative purposes, the economics of disposing of DU as a metal was evaluated and is presented in Appendix A.

The regulatory investigation established current regulatory definitions and requirements applicable to the $\mathrm{UF}_{6}$ in storage and the disposal of $\mathrm{U}_{3} \mathrm{O}_{8}$. Conclusions drawn support DOE's historical treatment of the DU as a "source material" solely regulated under the Atomic Energy Act (AEA) of 1954, as amended. Additionally, numerous federal statutes, with associated regulations/policies under the auspices of the DOE, the U.S. Nuclear Regulatory Commission (NRC), and the U.S. Environmental Protection Agency (EPA), are 
applicable to the disposal of the $\mathrm{U}_{3} \mathrm{O}_{8}$. The relevant statutes, regulations, and/or policies are detailed in Chapter 4.

Baseline cost estimates were established for disposing of the DU as $\mathrm{U}_{3} \mathrm{O}_{8}$ at the NTS and Hanford as low-level waste (LLW) and Resource Conservation and Recovery Act (RCRA) mixed waste (MW). These disposal scenarios represent the lower and upper bound of disposal costs at the DOE facilities investigated. The cost estimates range from a low of $\$ 3.4$ billion ( $\$ 9.50 / \mathrm{kgU}$ ) for direct LLW burial at NTS to a high of $\$ 10.9$ billion $(\$ 30.19 / \mathrm{kgU})$ for RCRA disposal at Hanford. The cost data are broken down in detail for each site and disposal scenario in Chapter 6 of this report.

Based on current conversion process technology and estimated costs associated with packaging, transporting, burial, and environmental compliance, disposal of the DU as $\mathrm{U}$ metal is more expensive than disposal as $\mathrm{U}_{3} \mathrm{O}_{8}$. This is due to the higher estimated cost for initial conversion (i.e., $\$ 3.61 \mathrm{~B}$ for $\mathrm{U}$ metal versus $3.0 \mathrm{~B}$ for $\mathrm{U}_{3} \mathrm{O}_{8}$ ).

- Conversion cost data obtained for the U metal disposal scenario varied considerably and are the most uncertain and/or sensitive to change.

- The greatest potential for reduction in overall disposal costs is in development of new conversion technologies with lower conversion costs and without secondary waste product (i.e., $\mathrm{CaF}_{2}$ and $\mathrm{MgF}_{2}$ ) disposal costs. 


\section{CONTENTS}

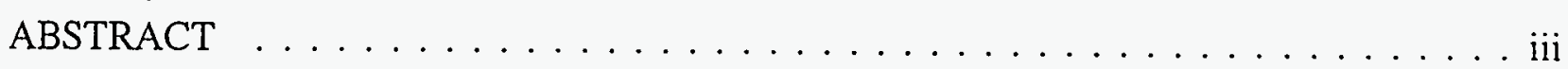

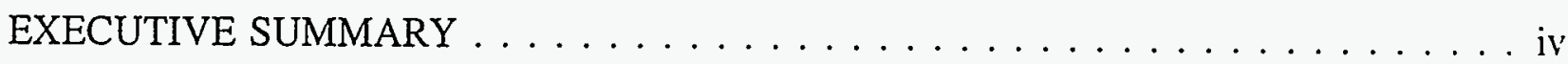

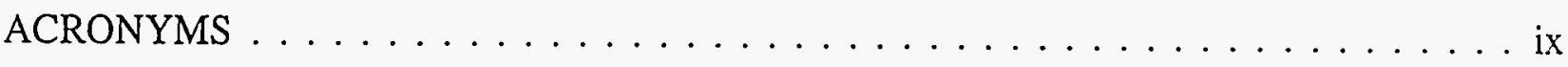

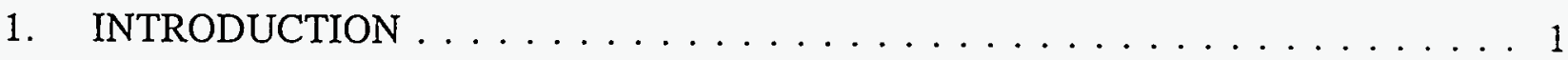

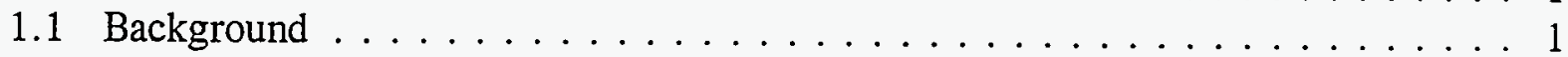

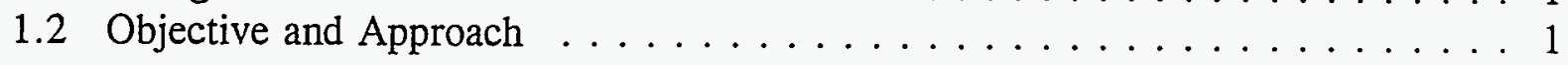

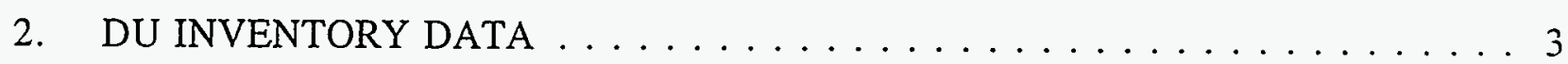

3. RADIOLOGICAL/CHEMICAL HAZARDS OF DU . . . . . . . . . . . . . 6

3.1 Hazards Affecting Disposal Alternatives . . . . . . . . . . . 6

3.1 .1 Radiological Toxicity of DU ................. 7

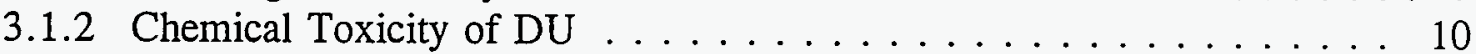

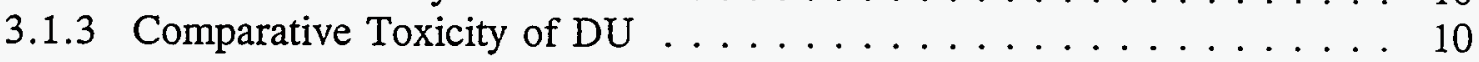

3.2 Preferred Chemical Form for Disposal $\ldots \ldots \ldots \ldots \ldots$

4. REGULATORY REVIEW . . . . . . . . . . . . . . . . . . . . . 14

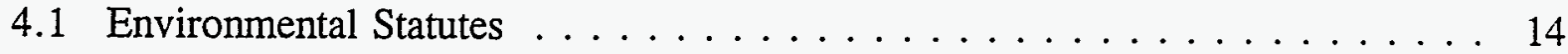

4.1 .1 The Atomic Energy Act . . . . . . . . . . . . . . . . 14

4.1.2 The Resource Conservation and Recovery Act ............ 15

4.1 .3 The Energy Policy Act . . . . . . . . . . . . . . . . . . . . . . . . . . . . . . . . . .

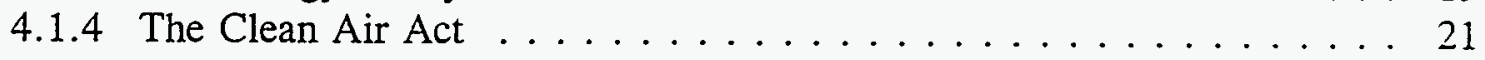

4.1.5 The National Environmental Policy Act . . . . . . . . . . . . 21

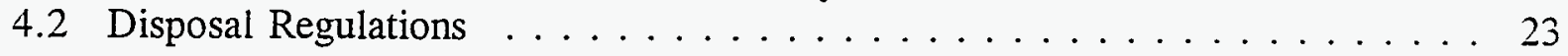

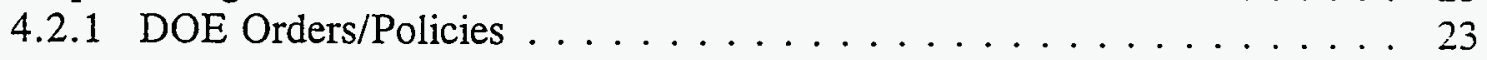

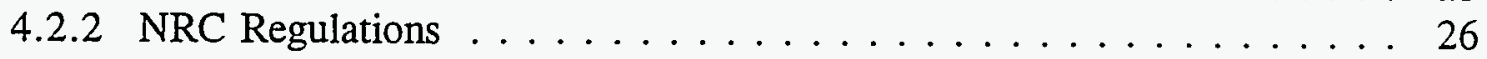

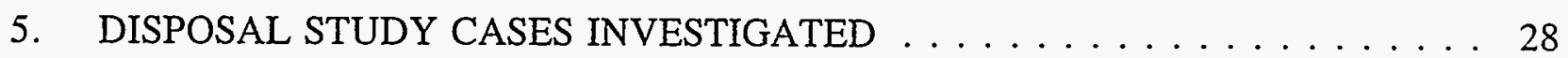

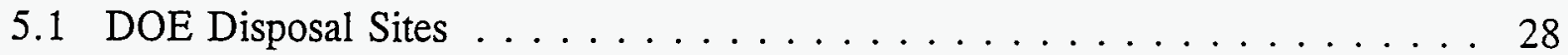

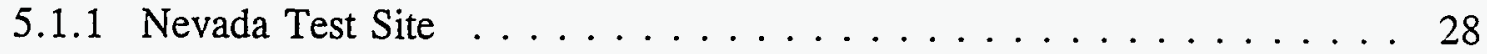

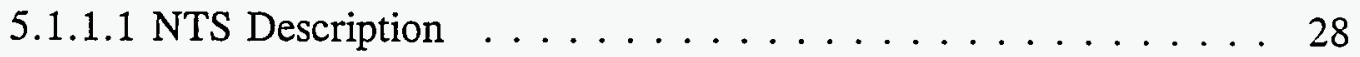

5.1.1.2 NTS Waste Acceptance Criteria .............. 33

5.1 .2 Hanford Site . . . . . . . . . . . . . . . . . . . . . . . . . . . . . . . . . 37

5.1.2.1 Hanford Site Description . . . . . . . . . . . . . 37

5.1.2.2 Hanford Waste Acceptance Criteria . . . . . . . . . . . . . 37

5.1.2.3 Hanford Site Disposal Costs . . . . . . . . . . . . . . . 41

5.2 Commercial Disposal Sites . . . . . . . . . . . . . . . 41

6. DISPOSAL COSTS ........................ 43 
6.1 Cost Estimate Objective and Approach ................ 45

6.2 Conversion Costs . . . . . . . . . . . . . . . . . . . . . . . 47

6.3 LLW Shallow-Land Burial Costs .................... 48

6.3 .1 Disposal Container Cost . . . . . . . . . . . . . . . . 48

6.3 .1 .1 NTS Disposal . . . . . . . . . . . . . . . . . . . . . . . . . . . . 48

6.3 .1 .2 Hanford Disposal . . . . . . . . . . . . . . . . . . . 48

6.3 .2 Transportation Cost . . . . . . . . . . . . . . . . . . . 50

6.3 .2 .1 NTS Disposal . . . . . . . . . . . . . . . . . . . . 50

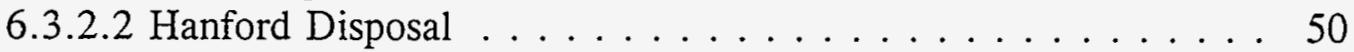

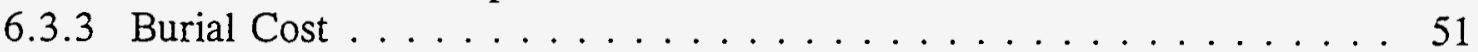

6.3 .3 .1 NTS Disposal . . . . . . . . . . . . . . . . . 51

6.3 .3 .2 Hanford Disposal . . . . . . . . . . . . . . . . 51

6.3 .4 Environmental Compliance Costs ................. 52

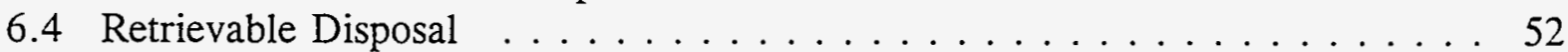

6.4 .1 Environmental Compliance Costs ............... 53

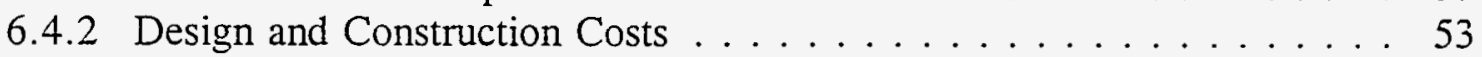

6.4 .3 Operational Costs . . . . . . . . . . . . . . . . . . . . 54

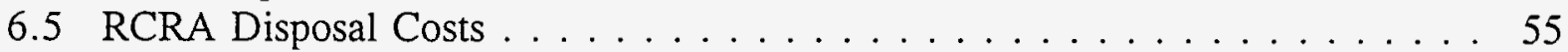

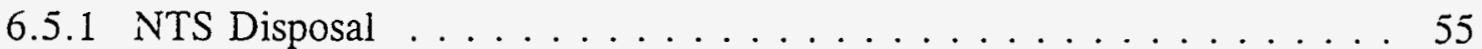

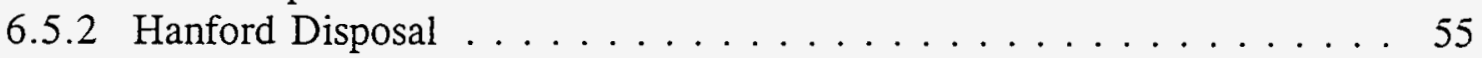

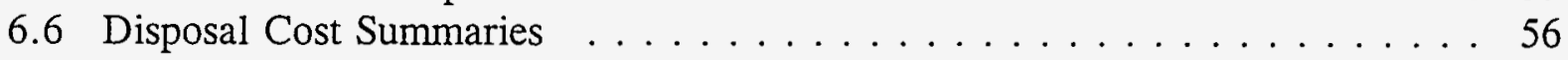

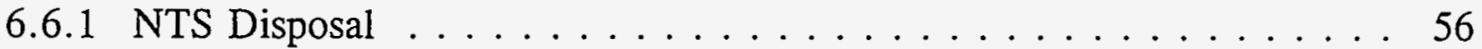

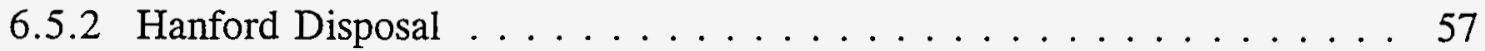

7. DEPLETED URANIUM DISPOSAL ISSUES . . . . . . . . . . . . . 58

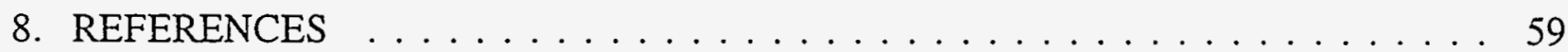

Appendix A -- Comparative Economics of Disposing DU as U Metal

\section{FIGURES}

1. General Location Map of the Nevada Test Site (DOE 1989) . . . . . . . . . . . . . . . . . . 29

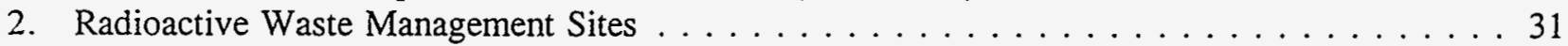

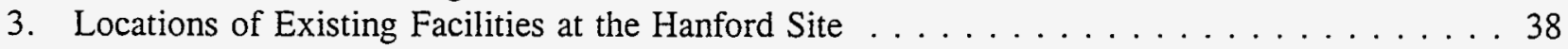

4. Cross-Section View of the AGEMCV . . . . . . . . . . . . . . . . . . . . 44

\section{TABLES}

1. DOE Depleted Uranium Inventory as of $6 / 30 / 92 \ldots \ldots \ldots \ldots \ldots \ldots \ldots$

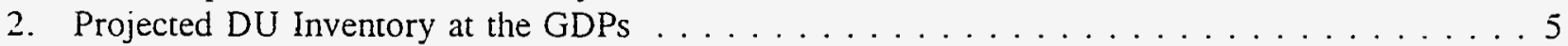

3. Radiological Properties of Uranium Isotopes and Decay Products $\ldots \ldots \ldots \ldots \ldots$

4. Uranium Specific Activities . . . . . . . . . . . . . . . . . . . . . . 8

5. Chemotoxicity Versus Radiotoxicity for Various Chemical Forms of Depleted Uranium . . . . 9

6. Threshold Limit Values In Air for Selected Metals . . . . . . . . . . . . . . . . . 10

7. Physical Properties of Selected Uranium Compounds . . . . . . . . . . . . . . . . 11 
8. Range of Measured Values for Uranium Distribution Coefficients . . . . . . . . . . . . 12

9. Proposed Uranium Waste Category Limits at Hanford . . . . . . . . . . . . . . . . . 40

10. Shallow-Land Burial Cost Estimates . . . . . . . . . . . . . . . . . . . 49

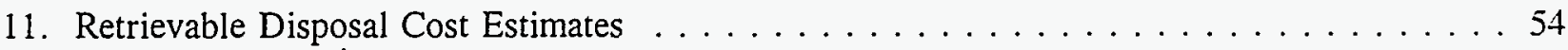

12. Disposal Costs Summary - 1993 Dollars . . . . . . . . . . . . . . . . . . . 56

A1. Cost Estimates for Low-Level Waste Disposal of DU as U Metal at NTS . . . . . . . . A A2

A2. Depleted Uranium Stoichiometric Mass Balance . . . . . . . . . . . . . A3 


\section{ACRONYMS}

AEA

AEC

AGEMCV

AVLIS

CAA

CWA

$\mathrm{DOE} / \mathrm{NV}$

DOE

DOT

DU

EIS

EPA

ES\&H

GCD

GDP

GTWC3

HMTA

INEL

LLW

LLWMU

LSA

MMES

MTU

MW

NEPA

NESHAP

NRC

NTS

$\mathrm{OAC}$

OSHA
Atomic Energy Act

Atomic Energy Commission

Above Grade Earth Mounded Concrete Vault

Atomic Vapor Laser Isotope Separation

Clean Air Act

Clean Water Act

DOE/Nevada Field Office

Department of Energy

Department of Defense

Depleted Uranium

Environmental Impact Statement

Environmental Protection Agency

Envirommental Safety and Health

Greater Confinement Disposal

Gaseous Diffusion Plant

Greater than Waste Category 3

Hazardous Materials Transportation Act

Idaho National Engineering Laboratory

Low-Level Waste

Low-Level Waste Management Unit

Low Specific Activity

Martin Marietta Energy Systems, Inc.

Metric Tons of Uranium

Mixed Waste

National Environmental Policy Act

National Emission Standards of Hazardous Air Pollutants

Nuclear Regulatory Commission

Nevada Test Site

Ohio Administrative Code

Occupational Safety and Health Administration 


$\begin{array}{ll}\text { PSD } & \text { Prevention of Significant Deterioration } \\ \text { PTC } & \text { Permit to Construct } \\ \text { RCRA } & \text { Resource Conservation and Recovery Act } \\ \text { REECo } & \text { Reynolds Electrical \& Engineering Co., Inc. } \\ \text { ROM } & \text { Rough order of magnitude } \\ \text { RWMS } & \text { Radioactive Waste Management Site } \\ \text { SAR } & \text { Safety Analysis Report } \\ \text { SDAR } & \text { Storage/Disposal Approval Record } \\ \text { SDWA } & \text { Safe Drinking Water Act } \\ \text { TLV } & \text { Threshold Limit Value } \\ \text { WAC } & \text { Waste Acceptance Criteria }\end{array}$




\section{DEPLETED URANIUM DISPOSAL OPTIONS EVALUATION}

\section{INTRODUCTION}

The Department of Energy (DOE), Office of Environmental Restoration and Waste Management, has chartered a study to evaluate alternative management strategies for depleted uranium (DU) currently stored throughout the DOE complex. Historically, DU has been maintained as a strategic resource because of uses for DU metal and potential uses for further enrichment or for uranium oxide as breeder reactor blanket fuel. This study has focused on evaluating the disposal options for DU if it were considered a waste. This report is in no way declaring these DU reserves a "waste," but is intended to provide baseline data for comparison with other management options for use of DU.

\subsection{Background,}

Naturally occurring uranium consists primarily of the stable isotope U-238, with only about $0.7 \%$ being the fissile isotope U-235. The U.S. government has been enriching uranium since the 1940s, initially for military needs. During the 1960s and 1970s, primary use of the enriched product shifted from military applications to providing fuel for commercial nuclear power plants. The Oak Ridge Gaseous Diffusion Plant (GDP) was the first operational uranium enrichment facility, followed by the Portsmouth and Paducah GDPs, which were built in the 1950s. The enrichment process involves separating a feed stream of natural uranium hexafluoride $\left(\mathrm{UF}_{6}\right)$ into a U-235-enriched product stream and a much larger by-product stream depleted in U-235. Generally, 5 to $10 \mathrm{~kg}$ of DU are produced for every kilogram of enriched uranium for commercial applications, while up to $200 \mathrm{~kg}$ of DU are produced for each kilogram of highly enriched uranium. ${ }^{1}$ Virtually all of the DU tails from the enrichment plants have been saved as a resource in the form of solid $\mathrm{UF}_{6}$. Continued enrichment of uranium ore to supply fuel to civilian reactor programs will increase the DU reserves.

DOE currently has a DU inventory of about 402,000 metric tons of uranium (MTU). The majority of DOE's DU is in the form of $\mathrm{UF}_{6}$ stored at the three GDPs in Paducah, KY; Piketon, $\mathrm{OH}$ (i.e., the Portsmouth GDP); and Oak Ridge, TN. (NOTE: The K-25 GDP in Oak Ridge has been shut down since 1985.) As of June 1992, the GDPs were storing 361,000 MTU (corresponding to approximately 534,000 metric tons of $\mathrm{UF}_{6}$ ), accounting for about $89.8 \%$ of DOE's total inventory of DU. ${ }^{a}$ Because of the limited near-term demand for DU and the large quantities of DU presently available, DOE is evaluating DU disposal options as well as other uses of DU.

\subsection{Objective and Approach}

The objective of this report is to provide DOE with baseline information that may be used to compare the costs of disposal with the costs of alternative uses of DU. Emphasis has been

a. Trygve Myhre, Depleted Uranium Inventory--June 30, 1992, TCM:EXCEL:DUDETAIL.XLS, September 29, 1992. 
placed on the disposal alternatives determined to be viable options based upon existing environmental. political/public opinion, and economic conditions. Three primary disposal options were identified and studied in depth: burial at a commercial site, burial at a DOE site, and retrievable disposal in vaults at a DOE site. However, disposal cost estimates were determined only for the DOE disposal site options because of the current limited accessibility of commercial disposal sites (see Section 5.2).

Because of the reactive nature of $\mathrm{UF}_{6}$, it has been assumed that the DU must first be converted to a form more suitable for disposal. Based upon information presented in Chapter 3 of this report, the uranium oxide $\left(\mathrm{U}_{3} \mathrm{O}_{8}\right)$ has been used as a reference form for disposal. Furthermore, cost estimates are based on disposal of DOE's DU inventory at the three GDPs as of June 30, 1992. Again, it should be emphasized that these assumptions in no way imply that any of this material will be declared waste and disposed of, but are only intended to outline a "worst-case" baseline for comparison to other potential DU management options and costs. The costs are presented in 1993 dollars even though conversion and disposal operations would probably not start for at least 10 years since there is presently little capability within the U.S. to convert $\mathrm{UF}_{6}$ to $\mathrm{U}_{3} \mathrm{O}_{8}$.

This document reports the following findings: DOE's current inventory of DU, radiological and chemical hazards of the various DU forms and the preferred chemical form for disposal, regulatory requirements applicable to DU disposal, and descriptions and preliminary costs for the primary disposal cases. 


\section{DU INVENTORY DATA}

DOE's current inventory of DU, as of June 30,1992 , is given in Table $1,{ }^{a}$ which provides data on quantities of DU stored at six different locations within the DOE complex. representing $91.85 \%$ of DOE's total inventory of $402,000 \mathrm{MTU}$ as of June 1992 . The majority of DOE's DU is currently in storage at the three GDPs in Paducah, KY; Piketon. OH: and Oak Ridge, TN. The 361,000 MTU of DU currently stored at the GDPs is in the form of UF $(534,000 \mathrm{MT})$ and represents approximately $90 \%$ of the total DOE inventory of DU. Therefore, in an effort to develop a consistent baseline for comparison to other options that will ultimately need to account for conversion costs, which vary depending on the initial DU form (e.g. $\mathrm{UF}_{6}$. $\mathrm{UO}_{3}$ ), this report will focus strictly on the DU stored as $\mathrm{UF}_{6}$ at the GDPs as of June 30, 1992.

The $\mathrm{UF}_{6}$ at the three GDPs is typically stored outdoors in painted steel cylinders with either 10- or 14-ton capacities. The majority of the storage containers are the 14-ton vessels, which are designated as thin-wall cylinders and coded as pressure vessels (working pressure rating of $100 \mathrm{psig}$, with a wall thickness of 5/16 in.). These cylinders currently qualify as "strong-tight containers" for transport of low-specific-activity (LSA) radioactive materials under Department of Transportation (DOT) regulations. The storage cylinder inventory at the end of FY-90 included 34,400 standard 14-ton cylinders at the three GDPs, with 22,300 at Paducah. 8.900 at Portsmouth and 3,200 at Oak Ridge. In addition, over 7,000 cylinders. of other types are also being used for DU storage. This includes thick-wall (5/8-in. thick) 14-ton cylinders, thin-wall and thick-wall 10-ton cylinders, and other miscellaneous cylinder types. ${ }^{1}$

Table 2 shows the quantities of $\mathrm{DU}$ expected to be generated by the diffusion plants through FY 2021. ${ }^{\mathrm{b}}$ During this time period, the Portsmouth and Paducah GDPs are projected to continue generating DU at a rate of about 15,700 MTU per year. As a result, by the end of FY 2021, the inventory of DU at the GDPs is anticipated to increase to about 817,000 MTU (or about $1,210,000 \mathrm{MT}$ of $\mathrm{UF}_{6}$ ). As discussed in Section 4.1.3, the DU generated by the GDPs after July 1, 1993, is expected to be the responsibility of the newly-formed U.S. Enrichment Corporation. Therefore, for purposes of this report, only the DU in storage as of June 1992 at the GDPs is being considered for the disposal baseline case. Assuming that the preferred disposal form will be $\mathrm{U}_{3} \mathrm{O}_{8}$ (see Chapter 3), the current inventory at the GDPs of $361,000 \mathrm{MTU}$ of DU (or $534,000 \mathrm{MT}$ of $\mathrm{UF}_{6}$ ) corresponds to $426,000 \mathrm{MT}$ of $\mathrm{U}_{3} \mathrm{O}_{8}$. Using the reported density of $\mathrm{U}_{3} \mathrm{O}_{8}$ after compaction, of $3 \mathrm{~g} / \mathrm{cm}^{3},{ }^{2}$ this represents a volume of $\mathrm{U}_{3} \mathrm{O}_{8}$ of 5 million $\mathrm{ft}^{3}$.

b. Carl Cooley, DOE-HQ/EM-50, Personal Communication with Tim Hertzler, SAIC, January 21, 1993. 
Table 1. DOE Depleted Uranium Inventory as of $6 / 30 / 92^{2}$

\section{Location}

Paducah GDP, MMES. UEA

\section{$\underline{\mathrm{U}-235 \text { Assav (Wt \%) }}$}

$$
\begin{gathered}
<0.21 \\
0.31 \text { to }<0.50 \\
0.24 \text { to }<0.26 \\
0.28 \text { to }<0.31 \\
0.60 \text { to }<0.711 \\
<0.21^{b} \\
0.26 \text { to }<0.28 \\
0.21 \text { to }<0.24 \\
0.50 \text { to }<0.60
\end{gathered}
$$

Portsmouth GDP, MMES, UEA

Oak Ridge GDP, MMES, UEA

Westinghouse Env'l Mgt Co. of Olio

Westinghouse Elect. Co., Columbia

West Hanford, Defense Ops

$$
\begin{gathered}
0.24 \text { to }<0.26 \\
0.31 \text { to }<0.50 \\
<0.21 \\
0.28 \text { to }<0.31 \\
0.21 \text { to }<0.24 \\
0.26 \text { to }<0.28
\end{gathered}
$$

Portsmouth GDP Total: $<0.21$

0.24 to $<0.26$

0.21 to $<0.24$

0.28 to $<0.31$

0.26 to $<0.28$

Oak Ridge GDP Total:

GDP TOTAL (89.82\%):

$$
\begin{aligned}
& <0.21^{\mathrm{c}} \\
& <0.21^{\mathrm{d}} \\
& <0.21^{\mathrm{c}} \\
& <0.21^{\mathrm{c}}
\end{aligned}
$$

$$
<0.21^{\mathrm{e}}
$$

0.60 to $<0.711^{t}$
WEMCO Total:

Weight (kgU)

73.573 .520

59.586 .050

51.882 .729

28.269.806

2.930 .985

$1,831.499$

$1,128.784$

751.960

506.479

Paducah GDP Total:

$220,461,812$

39.634 .865

$35.299,839$

20.628 .143

$+.584 .079$

2.696 .294

1.670 .520

$104.513,740$

22.750 .900

$9,546,178$

$1,822,524$

$1,573,650$

682.554

$36,375,806$

$361,351,358$

1.716 .373

$1.360,414$

828.196

542.749

$4,447,732$

$3.035,890$

670.188

GRAND TOTAL

(91.85\%):

a. All DU materials listed are from the enriching program, except those noted in footnotes $b$ to $f$.

b. Hex-to-Tetrafluoride.

c. Unirradiated scrap material awaiting recovery.

d. Reduction.

e. DOE program material computer generated product.

f. Irradiated material awaiting processing. 
Table 2. Projected DU Inventory at the GDPsa

\begin{tabular}{|c|c|c|}
\hline Fiscal Year & DU Inventory (MTU) & Annual DU Increase (MTU) \\
\hline Sept. 30, 1992 & 363,045 & ---- \\
\hline 1993 & 384,083 & 21,038 \\
\hline 1994 & 398,979 & 14,896 \\
\hline 1995 & 415,301 & 16,322 \\
\hline 1996 & 430,192 & 14,891 \\
\hline 1997 & 446,358 & 16,166 \\
\hline 1998 & 462,386 & 16,028 \\
\hline 1999 & 478,399 & 16,013 \\
\hline 2000 & 491,971 & 13,572 \\
\hline 2001 & 506,984 & 15,013 \\
\hline 2002 & 522,093 & 15,109 \\
\hline 2003 & 538,261 & 16,168 \\
\hline 2004 & 554,755 & 16,494 \\
\hline 2005 & 572,005 & 17,250 \\
\hline 2006 & 589,699 & 17,694 \\
\hline 2007 & 606,449 & 16,750 \\
\hline 2008 & 624,162 & 17,713 \\
\hline 2009 & 638,554 & 14,392 \\
\hline 2010 & 651,079 & 12,525 \\
\hline 2011 & 660,901 & 9,822 \\
\hline 2012 & 674,318 & 13,417 \\
\hline 2013 & 689,736 & 15,418 \\
\hline 2014 & 706,280 & 16,544 \\
\hline 2015 & 722,771 & 16,491 \\
\hline 2016 & 738,445 & 15,674 \\
\hline 2017 & 754,378 & 15,933 \\
\hline 2018 & 770,512 & 16,134 \\
\hline 2019 & 786,142 & 15,630 \\
\hline 2020 & 801,773 & 15,631 \\
\hline 2021 & 817,403 & 15,630 \\
\hline \multicolumn{3}{|c|}{$\begin{array}{l}\text { As a result of the Energy Policy Act of } 1992 \text {, it is expected that depleted uranium generated after July 1, 1993. will } \\
\text { become the responsibility of the U.S. Enrichment Corporation. }\end{array}$} \\
\hline
\end{tabular}




\section{RADIOLOGICAL/CHEMICAL HAZARDS OF DU}

This section provides an overview of the radiological and chemical hazards of uranium as they affect the choice of management options for DU. There are two related aspects to this discussion: (1) hazards associated with handling DU for disposal and (2) the behavior of uranium in the environment. The differences in environmental behavior of the various chemical forms of uranium are of particular importance since they provide a basis for selecting the optimum chemical form for disposal.

The acceptability of any disposal method for radioactive materials, including DU, must be demonstrated using a detailed performance assessment. These assessments must include a site-specific pathways analysis to estimate potential radiation doses to inadvertent intruders and off-site members of the general public. These analyses are required whether the radioactive material is disposed of as low-level radioactive waste in a commercial facility under 10 CFR 61 or at a DOE facility under DOE Order 5480.2A.

In either case, the performance objectives for the disposal method are defined by limits on the potential annual radiation dose of $25 \mathrm{mrem} / \mathrm{year}$ to any member of the general public from all pathways. In addition, any disposal site must also meet the requirements of the Clean Air Act (CAA) and the Clean Water Act (CWA). These limits are $10 \mathrm{mrem} / \mathrm{year}$ by atmospheric pathways and $4 \mathrm{mrem} / \mathrm{year}$ by the drinking water pathway. The required analyses include detailed modeling of releases from the disposal facility; transport through the environment by air, surface water, groundwater, and the food chain; and doses to people from inhalation, ingestion, and external exposure. Typically, the time period for which these estimates must be made is quite long, up to 10,000 years for some assessments.

In addition to radiological hazards, there are two categories of chemical hazards of concern in DU disposal. First, some chemical forms of uranium are sufficiently reactive that they can present hazards while handling for storage or disposal. Secondly, for all compounds of uranium, the potential risk from chemical toxicity is equal to or greater than that from radiotoxicity.

The relative performance of different chemical forms of $D U$, their hazards and environmental behavior, may be evaluated in a qualitative manner without conducting detailed analyses. The relative hazards of handling for disposal can be determined directly from their chemical properties. Their behavior in the environment is much more difficult to anticipate but data are available to support selection of an optimum chemical form for disposal.

\subsection{Hazards Affecting Disposal Altermatives}

The radiological and chemical toxicity hazards associated with the isotopes and chemical characteristics of DU are discussed below. Additionally, the behavior of the various forms of DU in the environment are presented in Section 3.2. This information establishes, on a qualitative basis, the form of DU least toxic to man and the most stable in the environment. Combining this information with the regulatory requirements for disposal of DU provides the basis for determining the preferred chemical form for disposal. 


\subsubsection{Radiological Toxicity of DU}

The radiological hazards of DU are a consequence of the properties of three isotopes of uranium: U-238, U-235, and U-234. The relative abundances of these three isotopes in naturally occurring uranium are $99.27 \%$ (U-238), $0.72 \%$ (U-235), and $0.0057 \%$ (U-234). Their abundances in DU vary somewhat but are typically $99.80 \%$ (U-238), $0.20 \%$ (U-235), and $0.0005 \%$ (U-234). Uranium enriched in U-235 can sustain a nuclear chain reaction (i.e., "go critical") under certain conditions of geometry and the presence of neutron moderating materials such as water. DU is safe against criticality under all conditions. ${ }^{3}$

The daughter products of these isotopes of uranium are also radioactive and form "decay chains" that contain many possible radionuclides. Uranium ore and its concentrates can contain a large number of these radionuclides including some, such as Ra-226, that present significant radiological hazards. However, the production of DU by gaseous diffusion results in essentially pure uranium without any decay products. Subsequent decay of initially pure uranium causes "ingrowth" of decay products.

The ingrowth of decay products in a serial decay chain depends on the rate of decay of the parent radionuclide into its daughter product and the subsequent decay of the daughter product into other radioactive isotopes in the series. This rate of ingrowth of decay products is based on the half-lives of the isotopes in the series. Generally, the time it takes for ingrowth of a decay product to reach an equilibrium activity with its predecessor depends on their half-lives. For a long-lived predecessor, the decay product will reach $99 \%$ of its equilibrium activity in about seven half-lives. When radionuclides in a decay series have long half-lives, such as U-238, U-234 and Th-230 (see Table 3 for half-lives), the resulting ingrowth of isotopes further along the decay chain (e.g., Ra-226) occurs very slowly. Applying this understanding of the rate of ingrowth to the U-238 decay chain for DU, the abundance of Ra-226 will be insufficient to produce a significant radiological hazard for tens of thousands of years.

Therefore, the only radionuclides that occur in sufficient abundance to have an impact on radiological hazards are Th-234 and $\mathrm{Pa}-234^{\mathrm{m}}$ from U-238 and Th-231 from U-235. ${ }^{3}$ Within a few months following production of DU, these isotopes will have built up to their maximum concentration. Thereafter, they will be produced by decay of uranium at the same rate as they decay, so their concentrations will remain constant. The radiological properties of these uranium isotopes and decay products are presented in Table 3 .

The radiological hazards of any radioactive material are proportional to the amount of radioactivity present. The various uranium isotopes, and mixtures of those isotopes, can be characterized by their "specific activity", defined as the amount of radioactivity (in Curies) per unit of mass (in grams). Radionuclides with longer half-lives have smaller specific activities. Because of its very long half-life, U-238 has little radioactivity per gram. In contrast, Ra-226 with a half-life of 1602 years has a specific activity of $1 \mathrm{Ci} / \mathrm{g}$. The specific activities of various mixtures of uranium isotopes are presented in Table 4.

There are some beta and gamma emissions from the isotopes of uranium and their decay products that require control in the work place. However, the external radiation hazards associated with uranium handling and storage are generally not a major concern. Whether in 
Table 3. Radiological Properties of Uranium Isotopes and Decay Products

\begin{tabular}{lll}
\hline Radionuclide & Half-life & $\begin{array}{l}\text { Principal } \\
\text { Radiation Types }\end{array}$ \\
\hline Uranium Isotopes: & & \\
\hline U-238 & $4.5 \times 10^{9}$ years & alpha \\
U-235 & $7.1 \times 10^{3}$ years & alpha, gamma \\
U-234 & $2.5 \times 10^{5}$ years & alpha \\
Decay Products: & & beta, gamma \\
Th-234 (from U-238) & 24.1 days & beta, gamma \\
Th-231 (from U-235) & 1.17 minutes & alpha. gamma \\
Th-230 (from U-234) & $8.0 \times 10^{4}$ years & beta, gamma \\
Pa-234 (from U-238) & 25.5 hours & \\
\hline
\end{tabular}

Table 4. Uranium Specific Activities

\begin{tabular}{lcc} 
Mixture & \%U-235 & $\begin{array}{c}\text { Specific Activity } \\
\text { (Ci/g) }\end{array}$ \\
\hline Pure U-238 & 0 & $3.33 \times 10^{-7}$ \\
Depleted & 0.20 & $4 \quad \times 10^{-7}$ \\
Natural & 0.72 & $7 \quad \times 10^{-7}$ \\
Enriched & 2.0 & $1 \quad \times 10^{-6}$ \\
Enriched & 20 & $9 \quad \times 10^{-6}$ \\
\hline
\end{tabular}

the work place or in the environment, the radiological hazards from DU are primarily due to alpha particle emission. This means that the internal radiation dose from ingestion or inhalation of uranium compounds is the limiting hazard under almost all circumstances.

How inhaled or ingested materials will be distributed and retained in the body depends on their chemical properties. Therefore, radiation doses are different for inhalation of different chemical compounds of uranium even when the amount of radioactivity inhaled is the same. The 
less soluble chemical forms are retained in the lungs for a longer period of time and are able to deliver a greater radiation dose than the soluble forms which clear from the lungs more rapidly. Three inhalation classes have been established. Uranium compounds such as $\mathrm{UF}_{6}$ are rapidly absorbed from the lung and have been assigned to class $\mathrm{D}$ with lung retention times in days. Less soluble compounds such as $\mathrm{UO}_{3}$ and $\mathrm{UF}_{4}$ have been assigned to class $\mathrm{W}$ with lung retention times in weeks. Highly insoluble uranium oxides such as $\mathrm{UO}_{2}$ and $\mathrm{U}_{3} \mathrm{O}_{8}$ have been assigned to class $\mathrm{Y}$ with lung retention times in years. ${ }^{4}$

The solubility classes for various chemical forms of uranium are listed in Table 5. This table also lists the air concentrations at which continuous exposure to DU will result in radiation doses that exceed the annual occupational limit. ${ }^{4}$ For mixtures of uranium isotopes with higher specific activities (i.e., greater enrichment of U-235), the limiting air concentrations for radiotoxicity would be more restrictive.

For ingestion of uranium, radiation doses are also different for different chemical compounds of uranium even when the amount of radioactivity is the same. The less soluble chemical forms are taken up by the kidney in smaller amounts than are the more soluble compounds. ${ }^{4}$ Table 5 lists the concentrations of different chemical forms of DU that would result in the EPA drinking water radiation dose limit of $4 \mathrm{mrem} / \mathrm{year}$.

Table 5. Chemotoxicity Versus Radiotoxicity for Various Chemical Forms of Depleted Uranium

\begin{tabular}{|c|c|c|c|c|c|c|c|}
\hline \multirow{3}{*}{$\begin{array}{l}\text { Chemical } \\
\text { Compound }\end{array}$} & \multirow[b]{3}{*}{ Class $^{2}$} & \multicolumn{3}{|c|}{ Limiting Air Concentration } & \multicolumn{3}{|c|}{ Limiting Water Concentration } \\
\hline & & \multirow{2}{*}{$\begin{array}{c}\text { Chemotoxicity } \\
\left(\mathrm{mg} / \mathrm{m}^{3}\right)\end{array}$} & \multicolumn{2}{|c|}{ Radiotoxicity $^{\mathrm{c}}$} & \multirow{2}{*}{$\begin{array}{l}\text { Chemotoxicity } \\
(\mu \mathrm{g} / \mathrm{L})\end{array}$} & \multicolumn{2}{|c|}{ Radiotoxicity $^{e}$} \\
\hline & & & $\left(\mathrm{pCi} / \mathrm{m}^{3}\right)$ & $\left(\mathrm{mg} / \mathrm{m}^{3}\right)$ & & $(\mathrm{pCi} / \mathrm{L})$ & $(\mu \mathrm{g} / \mathrm{L})$ \\
\hline $\mathrm{U}_{3} \mathrm{O}_{8}$ & $\mathrm{Y}$ & 0.68 & 189 & 0.47 & 60 & 220 & 550 \\
\hline $\mathrm{UO}_{2}$ & $Y$ & 0.68 & 189 & 0.47 & 60 & 220 & 550 \\
\hline $\mathrm{UF}_{4}$ & W & 0.28 & 270 & 0.68 & 60 & 22 & 55 \\
\hline $\mathrm{UO}_{3}$ & W & 0.28 & 270 & 0.68 & 60 & 22 & 55 \\
\hline $\mathrm{UF}_{6}$ & $\mathrm{D}$ & 0.07 & 540 & 1.35 & 60 & 22 & 55 \\
\hline
\end{tabular}

a. Inhalation solubility classes established by the International Commission on Radiological Protection.

b. Air concentration at which constant exposure results in a steady state kidney burden of $0.330 \mathrm{mg}$ (about $1 \mu \mathrm{g} / \mathrm{g}$ of kidney tissue). The OSHA occupational limit for continuous exposure is $0.05 \mathrm{mg} / \mathrm{m}^{3}$ based on chemical toxicity.

c. Air concentration at which constant exposure results in a radiation dose equal to the annual occupational limit of $5 \mathrm{rem} / \mathrm{year}$. Conversion from $\mathrm{pCi} / \mathrm{m}^{3}$ to $\mathrm{mg} / \mathrm{m}^{3}$ is based on a DU specific activity of $4 \times 10^{-7}$ $\mathrm{Ci} / \mathrm{g}$.

d. Proposed EPA standard for naturally occurring uranium in drinking water based on chemical toxicity.

e. Drinking water concentration which would result in an annual dose equalling the EPA drinking water standard of $4 \mathrm{mrem} / \mathrm{year}$. Conversion from $\mathrm{pCi} / \mathrm{L}$ to $\mu \mathrm{g} / \mathrm{L}$ is based on a $\mathrm{DU}$ specific activity of $4 \times 10^{-7}$ Ci/g. 3.2 BEHAVIOR OF URANIUM IN THE ENVIRONMENT. 


\subsubsection{Chemical Toxicity of DU}

Historically, the chemical toxicity of uranium has been a primary concern in establishing occupational and environmental limits for DU. In occupational situations, uranium is considered only slightly less toxic than lead. ${ }^{3}$ Table 6 indicates the relative toxicity of uranium and other metals. ${ }^{5}$ The threshold limit value (TLV) in air for occupational exposures is used here for purposes of comparison.

Uranium is toxic to the kidneys and high exposure to soluble compounds can result in renal injury. A concentration of about $1 \mu \mathrm{g} / \mathrm{g}$ of kidney tissue has been used as a guideline for controlling the chemical toxicity of uranium. Since the average adult male has a kidney mass of about $330 \mathrm{~g}$, this is equivalent to a total kidney burden of $0.330 \mathrm{mg}$.

Table 5 lists the air concentration at which constant exposure results in a steady state kidney burden of $0.330 \mathrm{mg}$ for various chemical forms of uranium. The differences among the chemical forms listed are attributable to their relative solubilities and the degree to which they are taken up by the kidneys. The Occupational Safety and Health Administration (OSHA) standard ${ }^{6}$ for continuous occupational exposure is $0.05 \mathrm{mg} / \mathrm{m}^{3}$, which is slightly more restrictive than the $0.07 \mathrm{mg} / \mathrm{m}^{3}$ calculated for the most soluble chemical form listed, UF $\mathrm{F}_{6}$. Table 5 also lists the proposed Environmental Protection Agency (EPA) drinking water limit for naturally occurring uranium based on chemical toxicity. The derivations of both the OSHA and the EPA drinking water limits are based on the most soluble chemical forms of uranium. Since these limits are based only on the chemical properties of uranium, they would be the same for all mixtures of uranium isotopes regardless of specific activity (i.e., for all enrichments).

\subsubsection{Comparative Toxicity of DU}

For DU, the chemical and radiological toxicities of all compounds of uranium are generally of the same order of magnitude. Table 5 allows a comparison of the radiological and chemical

Table 6. Threshold Limit Values In Air for Selected Metals

\begin{tabular}{lcc}
\hline Metal & $\begin{array}{c}\text { TLV-TWA } \\
\left(\mathrm{mg} / \mathrm{m}^{3}\right)\end{array}$ & $\begin{array}{c}\text { TLV-STEL } \\
\left(\mathrm{mg} / \mathrm{m}^{3}\right)\end{array}$ \\
\cline { 2 - 3 } Uranium & 0.2 & 0.6 \\
Beryllium & 0.002 & - \\
Lead & 0.15 & 0.45 \\
Arsenic & 0.2 & -- \\
Mercury & 0.05 & - \\
\hline a. Threshold Limit Value - Time Weighted Average & \\
b. Threshold Limit Value - Short Term Exposure Limit &
\end{tabular}


toxicities of various compounds. Whether radiotoxicity or chemotoxicity is limiting depends on the measure used and the uranium compound of interest.

In occupational situations, where inhalation is the primary concern and the radiation dose limits are high, chemical toxicity is limiting for the more soluble compounds and radiotoxicity is limiting for the insoluble compounds. This is because insoluble compounds are retained by the lungs for a longer period of time and result in higher radiation doses. In environmental situations, the reverse is true because drinking water is the primary concern and radiation dose limits are very restrictive. Thus chemical toxicity is limiting for insoluble compounds and radiotoxicity is limiting for the soluble compounds.

The environmental behavior of the various compounds of uranium is controlled by their physical and chemical properties. The complexity of uranium chemistry and the strong influence of site-specific conditions make prediction of precise environmental behavior extremely difficult. In general, however, the more reactive compounds and the more soluble compounds have the least desirable behavior in the environment. Table 7 lists the physical properties of selected uranium compounds. ${ }^{1}$

Of the compounds listed in Table $7, \mathrm{UF}_{6}$ is the most reactive. It is a solid at standard temperature and pressure, but is volatile and sublimes at $56^{\circ} \mathrm{C}$. It reacts with water to form soluble uranyl fluoride $\left(\mathrm{UO}_{2} \mathrm{~F}_{2}\right)$ and hydrogen fluoride $(\mathrm{HF})$ gas. Uranium tetrafluoride, $\mathrm{UF}_{4}$ reacts slowly with moisture at ambient temperature to form uranium dioxide $\left(\mathrm{UO}_{2}\right)$ and $\mathrm{HF}$. $\mathrm{UO}_{2}$ will slowly convert to $\mathrm{U}_{3} \mathrm{O}_{8}$ in air at ambient temperature. $\mathrm{U}_{3} \mathrm{O}_{8}$ is the most inert chemical

Table 7. Physical Properties of Selected Uranium Compounds

\begin{tabular}{|c|c|c|c|c|}
\hline \multirow{2}{*}{$\begin{array}{l}\text { Chemical } \\
\text { Compound }\end{array}$} & \multirow{2}{*}{$\begin{array}{l}\text { Melting point } \\
\quad\left({ }^{\circ} \mathrm{C}\right) \\
\end{array}$} & \multicolumn{2}{|c|}{ Density $\left(\mathrm{g} / \mathrm{cm}^{3}\right)$} & \multirow{2}{*}{$\begin{array}{l}\text { Solubility in } \\
\text { Water, neutral pH }\end{array}$} \\
\hline & & Crystal & Bulk & \\
\hline$U_{6}$ & 64 & 4.7 & 4.6 & $\begin{array}{l}\text { Soluble, } \\
\text { Decomposes to } \\
\mathrm{UO}_{2} \mathrm{~F}_{2}\end{array}$ \\
\hline $\mathrm{UF}_{4}$ & 960 & 6.7 & $2.0-4.5$ & $\begin{array}{l}\text { Very slightly } \\
\text { soluble }\end{array}$ \\
\hline $\mathrm{UO}_{3}$ & $\begin{array}{l}\text { Decomposes to } \\
\mathrm{U}_{3} \mathrm{O}_{8} \text { when } \\
\text { heated }\end{array}$ & 7.3 & $1.5-4.5$ & Insoluble \\
\hline $\mathrm{U}_{3} \mathrm{O}_{8}$ & $\begin{array}{l}\text { Decomposes to } \\
\mathrm{UO}_{2} \text { at } 1300\end{array}$ & 8.3 & $1.5-4.0$ & Insoluble \\
\hline $\mathrm{UO}_{2}$ & 2878 & 11.0 & $2.0-5.0$ & Insoluble \\
\hline U & 1132 & 19.1 & 19.0 & Insoluble \\
\hline
\end{tabular}


form of uranium; it has low chemical reactivity and low solubility. All other forms tabulated above will convert to $\mathrm{U}_{3} \mathrm{O}_{8}$ under most environmental conditions. ${ }^{1}$

The chemistry of uranium is quite complex: uranium can exist in valence states of 3.4.5. or 6. Uranium in the environment commonly exists in one of two chemical states: the oxidized +6 valence state and the reduced $\div 4$ valence state. Hexavalent uranium $\left(U^{-6}\right)$ compounds are known to have significantly greater solubility and are much more mobile in the environment than tetravalent $\left(U^{-4}\right)$ compounds. Typical solubility limits in groundwater of neutral $\mathrm{pH}$ are in the range of $6 \times 10^{-2} \mathrm{mg} / \mathrm{L}$ for hexavalent compounds and $7 \times 10^{-3} \mathrm{mg} / \mathrm{L}$ for the tetravalent oxides of uranium. ${ }^{7}$

Solubility is one measure of environmental mobility. However, the behavior of uranium in the environment is strongly influenced by environmental conditions. This is illustrated by the wide range of measured values for the distribution coefficient, $K_{d}$. The $K_{d}$ is a measure of how tightly bound a compound is to individual soil particles. A high $\mathrm{K}_{\mathrm{d}}$ indicates a compound that remains associated with soils and sediments in the environment and is not easily moved by groundwater. A low $\mathrm{K}_{\mathrm{d}}$ indicates a compound that can be expected to move rapidly through groundwater systems to become available for later uptake by plants, animals, or people. Table 8 presents several measured values of the distribution coefficient for hexavalent and tetravalent uranium in different soils. ${ }^{8}$ These values range over a factor of more than 10,000 (from 62,000 to 3 ), indicating a very large dependence on local soil conditions.

Uptake of uranium by plants, animals, and people is generally quite low. Uranium serves no nutritional function and is not chemically similar to any required nutrient, so there are no active metabolic processes to concentrate uranium in the food chain. ${ }^{7}$ For most waste disposal assessments, transfer by groundwater and ultimate contamination of drinking water sources will be the limiting pathway for human exposures.

\subsection{Preferred Chemical Form for Disposal}

With respect to the radiological and chemical characteristics of DU and the potential impact to man. the choice of a preferred chemical form for disposal of DU is based on three considerations: (1) potential for release (i.e., solubility and dispersibility), (2) environmental behavior (i.e., reactivity, solubility, and $\mathrm{K}_{d} \mathrm{~s}$ ), and (3) relative toxicity in drinking water. The foregoing summary of uranium toxicity and environmental behavior indicates that $\mathrm{U}_{3} \mathrm{O}_{8}$ is one

Table 8. Range of Measured Values for Uranium Distribution Coefficients

\begin{tabular}{rll}
\hline $\mathrm{K}_{\mathrm{d}}(\mathrm{mL} / \mathrm{g})$ & & Conditions \\
\cline { 2 - 3 } & & \\
62.000 & & Silt loam, $\mathrm{U}^{+6}, \mathrm{pH} 6.5$ \\
4,400 & & Clay soil, $\mathrm{U}^{+6}, \mathrm{pH} 6.5$ \\
2,000 & & Clay soil, $\mathrm{UO}^{+2}, \mathrm{pH} 10$ \\
300 & & Clay soil, $\mathrm{UO}^{+2}, \mathrm{pH} 5.5$ \\
3 & Limestone, $\mathrm{UO}^{+2}, \mathrm{pH} 6.9$ \\
\hline
\end{tabular}


of the best choices for a final form. It is chemically stable, insoluble, and of low toxicity in drinking water-desirable properties for shallow land disposal. This choice of a final waste form parallels the practice currently being followed by the French in converting their depleted uranium hexafluoride to $\mathrm{U}_{3} \mathrm{O}_{8}$ for disposal. ${ }^{1,2}$

In addition to the toxicity aspects of the various forms of DU, established regulatory criteria restrict certain forms of $\mathrm{DU}$ from disposal. As previously stated, $\mathrm{UF}_{6}$ is reactive when exposed to moisture. Reactive waste forms are specifically restricted from disposal by the Nevada Test Site (NTS) and Hanford waste acceptance criteria (WAC) and DOE orders. In addition, finely divided DU metal is pyrophoric and is restricted from disposal by site-specific WAC. However, in limited cases "bulk" DU metal has been accepted for disposal at the NTS as mentioned in Appendix A of this report.

Based on the qualitative assessments in Sections 3.1 and 3.2 and specific regulations restricting various forms of DU from disposal, the remainder of this report will evaluate the general requirements and costs for the disposal of $\mathrm{DU}$ as $\mathrm{U}_{3} \mathrm{O}_{8}$. However, the choice of $\mathrm{U}_{3} \mathrm{O}_{8}$ as the referenced waste form in this study does not preclude the disposal of DU in another form(s) (e.g., $\mathrm{UO}_{2}, \mathrm{U}$ metal) if it can be shown to be environmentally stable, acceptable per all regulatory criteria, and more economical. 


\section{REGULATORY REVIEW}

Regulatory requirements applicable to the management and disposal of DU are in a state of flux as a result of changes in federal statutes and associated regulations/policies under the auspices of the DOE, the U.S. Nuclear Regulatory Commission (NRC), and the U.S. Environmental Protection Agency (EPA). The relevant statutes, regulations, and/or policies are discussed below.

\subsection{Environmental Statutes}

\subsubsection{The Atomic Energy Act}

The purpose of the Atomic Energy Act (AEA) of 1954 [Public Law 83-703, as amended] was to ensure the proper management of source, special nuclear material, and byproduct material. These terms are defined as follows:

The term "source material" means (1) uranium, thorium, or any other material which is determined by the Commission pursuant to the provisions of Section 61 to be source material; or (2) ores containing one or more of the foregoing materials, in such concentration as the Commission may by regulation determine from time to time. [AEA, $\S 11(\mathrm{z})]$

The term "special nuclear material" means (1) plutonium, uranium enriched in the isotope 233 or the isotope 235 , and any other material which the Commission, pursuant to the provisions of Section 51 of this Act, determines to be special nuclear material, but does not include source material; or (2) any material artificially enriched by any of the foregoing, but does not include source material. [AEA, § 11(aa)]

The term "byproduct material" means (1) any radioactive material (except special nuclear material) yielded in or made radioactive by exposure to the radiation incident to the process of producing or utilizing special nuclear material, and (2) the tailings or wastes produced by the extraction or concentration of uranium or thorium from any ore processed primarily for its source material. [AEA, § 11(e)]

Section 161 of the AEA provides the authority to establish "by rule, regulation, or order, such standards and instructions to govern the possession and use of special nuclear material, source material, and byproduct material as the ...(AEC)... may deem necessary or desirable to promote the common defense and security or to protect health or to minimize danger to life or property." This and other sections, such as 2,3 , and 41 , allow DOE to set radiation protection standards for itself and its contractors. The NRC licensing powers are defined in Sections 101-111. Sections 91 and 110 of the AEA provide exclusions from licensing for defense production facilities. Although DOE low-level waste (LLW) disposal sites are excluded from NRC licensing requirements, such disposal is governed by DOE orders and policies that are largely reflected in each disposal site's WAC. DOE orders applicable to the potential disposal of DU as LLW are discussed further in Section 4.2.1, while site-specific WAC requirements are discussed in Chapter 5. 
Prior to 1954, nuclear energy activities were largely confined to the federal government. The AEA amendments of 1954 encouraged private commercial firms to enter into the development and utilization of nuclear energy for peaceful purposes by allowing non-federal ownership of nuclear production and utilization facilities if an operating license was obtained from the Atomic Energy Commission (AEC). Licensing requirements (now controlled by either NRC or states that have formal agreements with NRC to assume regulatory authority) are still applicable to the disposal of DOE's DU in commercial disposal sites. Any DU targeted for disposal at a commercial LLW disposal site must satisfy all requirements and conditions specified in the site's radioactive materials license. Site-specific license requirements for existing commercial facilities are discussed further in Sections 4.2.2 and 5.2.

Of even greater importance to DOE's management of its DU, is the fact that source material (as previously defined) is subject to regulation under the AEA. Section 61 of the AEA, as amended, gave the Atomic Energy Commission the following authority:

The Commission may determine from time to time that other material is source material in addition to those specified in the definition of source material. Before making such determination, the Commission must find that such material is essential to the production of special nuclear material and must find that the determination that such material is source material is in the interest of the common defense and security, and the President must have expressly assented in writing to the determination.

As a result, the Atomic Energy Commission promulgated the following regulatory definitions in $10 \mathrm{CFR} \S 40.4$ :

Source material means: (1) Uranium or thorium, or any combination thereof, in any physical or chemical form or (2) ores which contain by weight one-twentieth of one percent $(0.05 \%)$ or more of: (i) Uranium, (ii) thorium or (iii) any combination thereof. Source material does not include special nuclear material.

Depleted uranium means the source material uranium in which the isotope uranium-235 is less than 0.711 weight percent of the total uranium present. Depleted uranium does not include special nuclear material.

Consistent with these definitions, DOE has historically treated DU as source material subject to regulation under the AEA of 1954, as amended. For purposes of this report, it has been assumed that DU will continue to be solely under AEA jurisdiction if disposed of as LLW waste at some point in the future-i.e., subject to DOE orders at DOE disposal sites and subject to NRC licensing criteria at commercial disposal sites. This assumption may not be valid in the future, based upon recent developments within the hazardous waste regulatory arena, as discussed in the following section.

\subsubsection{The Resource Conservation and Recovery Act}

In 1976, Congress remodeled a law that primarily addressed the disposal of nonhazardous waste, the Solid Waste Disposal Act, building into it a major new program on hazardous waste. The new law was meant to encourage more than pollution control-Congress intended to 
discourage the production of hazardous waste in the first place and encourage the development of advanced forms of material recycling and recovery. The purposes of the comprehensive new law, the Resource Conservation and Recovery Act (RCRA), were to: protect human health and the environment, expeditiously reduce or eliminate the generation of hazardous waste, and conserve energy and natural resources. RCRA enforcement is the responsibility of the EPA, which issues regulations concerning generation, transport, treatment, storage. and disposal of hazardous waste (primarily found in $40 \mathrm{CFR}$ parts 260 through 272). However, Section 3006 of RCRA authorizes states to develop and enforce their own hazardous waste programs in place of the federal program administered by the EPA. State hazardous waste programs must be reviewed and approved by EPA before the state is given authority to implement and enforce its own program.

In general, RCRA regulates "solid waste," which includes both ordinary garbage generated in households and offices and the more hazardous chemical wastes produced by industry. These two categories of waste are handled very differently in both the law itself and in its implementing regulations. Subtitle $\mathrm{D}$ of the statute deals with nonhazardous municipal solid wastes, which are currently regulated almost entirely by the states under minimal federal guidelines. Subtitle $C$ addresses the management of hazardous waste. For a waste to be hazardous within the meaning of RCRA, it must first meet the definition of a solid waste. A waste that does not meet the solid waste definition cannot be defined as a hazardous waste. RCRA defines solid waste and hazardous waste as follows:

The term "solid waste" means any garbage, refuse, sludge from a waste treatment plant, water supply treatment plant, or air pollution control facility and other discarded material, including solid, liquid, semisolid, or contained gaseous material resulting from industrial, commercial, mining, and agricultural operations, and from community activities, but does not include solid or dissolved material in domestic sewage, or solid or dissolved materials in irrigation return flows, or industrial discharges which are point sources subject to permits under section 402 of the Federal Water Pollution Control Act. as amended (86 Stat. 880), or source, special nuclear. or byproduct material as defined by the Atomic Energy Act of 1954, as amended (68 Stat. 923). [RCRA \& 1004(27)]

The term "hazardous waste" means a solid waste, or combination of solid wastes, which because of its quantity, concentration, or physical, chemical or infectious characteristics may: (1) cause, or significantly contribute to an increase in mortality or an increase in serious irreversible, or incapacitating reversible, illness; or (2) pose a substantial present or potential hazard to human health or the environment when improperly treated, stored, transported, or disposed of, or otherwise managed. [RCRA $\S 1004(5)]$

In regulations implementing RCRA [40 CFR 261.4(a)], the EPA states the following exclusion: "The following materials are not solid wastes for the purpose of this part: ...(4) Source, special nuclear or byproduct material as defined by the Atomic Energy Act of 1954, as amended, 42 U.S.C. 2011 et seq." 
Consistent with these definitions and regulatory exclusions, the depleted uranium hexafluoride at the GDPs has traditionally been managed as material that was exempt from the regulatory jurisdiction of both the federal EPA and state agencies with respect to hazardous waste requirements under Subtitle $C$ of RCRA. This practice was based upon the position that since the DU consists solely of $\mathrm{UF}_{6}$ it meets the definition of source material and should be regulated strictly under the AEA. The gaseous diffusion process uses $\mathrm{UF}_{6}$ containing $0.71 \%$ U-235 as feed material. The feed material, which arrives in cylinders in solid form, is heated in its cylinder to a gaseous state and fed into a cascade consisting of a series of compressors and separation barriers. By physical separation only, the cascade increases the percent of U-235 in the "enriched" UF 6 product stream and decreases the U-235 content in the much larger "depleted" UF 6 tails stream. This latter stream constitutes the DU that is currently stored at the three GDPs as a resource, primarily because it is still capable of being used as feed material to produce enriched uranium. No chemicals or other materials are added to the $\mathrm{UF}_{6}$ during the enrichment process or prior to storage of the depleted $\mathrm{UF}_{6}$ in cylinders. ${ }^{\mathrm{c}}$ Therefore, the DU does not contain any extraneous "non-AEA" material that would qualify as either a characteristic or listed hazardous waste.

In recent years, the issue of the applicability of hazardous waste regulations to DOE's UF 6 inventories in storage has been raised by the Ohio EPA, specifically concerning the DU stored at the Portsmouth GDP in Piketon, OH. The Southeast District Office of the Ohio EPA notified the DOE in October 1990 that cylinders of DU at the Portsmouth GDP were no longer exempt from regulation as a hazardous waste under Ohio Administrative Code (OAC) 3745-51-04. ${ }^{\text { }}$ This section of the Ohio Waste Management Regulations contains the solid waste exclusions comparable to the federal solid waste exclusions of $40 \mathrm{CFR} 261.4$ (a). The federal exclusion for source, special nuclear, or byproduct material has been omitted from OAC 37455104. However, the Ohio Solid and Hazardous Waste Disposal Law, Ohio Revised Code 3734.01(J), does contain the following:

Hazardous waste means any waste or combination of wastes in solid, semisolid, or contained gaseous form that in the determination of the director because of its quantity, concentration, or physical or chemical characteristics, may: (1) cause or significantly contribute to an increase in serious irreversible or incapacitating reversible illness; or (2) pose a substantial present or potential hazard to human health or safety or to the environment when improperly stored, treated, transported, disposed of, or otherwise managed. Hazardous waste includes any substance identified by regulation as hazardous under the Resource Conservation and Recovery Act of 1976, 90 Stat. 2806, 42 U.S.C. 6921, as amended, and does not include any substance that is subject to the 'Atomic Energy Act of 1954.' 68 Stat. 919. 42 U.S.C. 2011.

c. Joe La Grone, Manager DOE Oak Ridge Operations, letter to Richard Shank, Director Ohio EPA, dated October 29, 1990.

d. Donna Goodman, Inspector Ohio EPA, Division of Solids \& Hazardous Waste Management, letter to E. W. Gillespie, Site Manager U.S. DOE Portsmouth, Ohio, dated September 27, 1990. 
The DOE responded in an October 29, 1990 letter from the manager of the DOE-Oak Ridge Operations to the Director of the Ohio EPA, ${ }^{\text {c.1 }}$ stating that, "The cylinders of depleted uranium are exempt from regulation because uranium hexafluoride is 'source material' under the Atomic Energy Act of 1954, as amended." In an attached regulatory analysis, DOE's position was supported by citing the statutory and regulatory definitions and exclusions within the AEA. RCRA, and the Ohio Revised Code. Additionally, the analysis contained the following:

Source material clearly is a substance that is subject to the AEA. Therefore, depleted uranium, having been defined by the Atomic Energy Commission as a source material is not a hazardous waste under Ohio law.

The depleted uranium stored at PORTS also is not a mixed waste subject to regulation as a hazardous waste, because the depleted uranium is not mixed with a RCRA hazardous waste. There is no other material, waste or otherwise, in the storage cylinder of uranium hexafluoride.

USEPA announced its mixed waste policy in the Federal Register on July 3, 1986 (51 FR 24504). That policy and subsequent clarifications issued by USEPA indicate that USEPA intended to regulate as "mixed wastes" those radioactive materials that become mixed with a non-AEA material that is a hazardous waste. Radioactive materials, such as the depleted uranium stored at our Portsmouth facility, that have not been mixed with a non AEA material that is a hazardous waste are not considered "mixed wastes" regulated by RCRA. See Guidance on Identification of Low-Level Radioactive and Hazardous Waste, 52 FR 11147.

In summary, the $\mathrm{UF}_{6}$ tails qualify as "source material" under the AEA. Source materials are exempt from regulation under RCRA and Ohio law by statute. USEPA's "mixed waste" policy does not apply to depleted uranium, because this material has not been mixed with a listed hazardous waste or non-AEA material which exhibits a hazardous waste characteristic.

This issue remains unresolved. On January 13, 1993, the Ohio EPA reiterated their position to $\mathrm{DOE}$ that $\mathrm{UF}_{6}$, in their view, was a radioactive mixed waste regulated under Ohio hazardous waste laws because it qualifies as a discarded material/waste and is not excluded under any Atomic Energy Act exemption or the Ohio Revised Code 3745-51-04. ${ }^{e}$ The DOE Office of Chief Counsel in the Oak Ridge Operations Office is currently handling the legal analysis and negotiations concerning this matter. The outcome of this legal action may greatly impact any future disposal options for DOE's DU. If the depleted uranium hexafluoride is ultimately categorized as a hazardous waste, disposal requirements for DU may become much more complicated. Disposal in a RCRA-permitted facility and compliance with RCRA land disposal restrictions and treatment levels/methods, depending on the hazardous waste designation, would then apply. It should be noted that the states of Kentucky and Tennessee have not yet raised similar issues for the DU stored at the Paducah and Oak Ridge GDPs, respectively.

e. Beverly Stephens, DOE/OR Office of Chief Counsel, Personal Communication with Doug Nishimoto, SAIC, March 4, 1993. 
For purposes of this report, it has been assumed that any disposal of DU by DOE in the future will remain subject strictly to AEA jurisdiction as source material/low-level waste.

\subsubsection{The Energy Policy Act}

The Energy Policy Act of 1992 (Public Law 102-486-Oct. 24, 1992) included provisions for amending the Atomic Energy Act of 1954 with respect to DOE's uranium enrichment activities. Specifically, Titles IX, X, and XI of the Energy Policy Act address establishment of the U.S. Enrichment Corporation; remedial action at active processing sites and uranium revitalization; and uranium enrichment health, safety, and environmental issues. In summary, these portions of the Act affect the DOE by: (1) assigning DOE's uranium enrichment activities to a private corporation as of July 1,1993 , (2) maintaining DOE as the responsible party for DU generated prior to July 1,1993, and for remedial action and decontamination and decommissioning activities at the GDPs, and (3) assigning responsibility for the development and commercialization of alternative enrichment technologies such as Atomic Vapor Laser Isotope Separation (AVLIS) to the Corporation.

Sections 1202 and 1301 of the Energy Policy Act contain the following:

The Corporation [U.S. Enrichment Corporation] is created for the following purposes:

1. To operate as a business enterprise on a profitable and efficient basis.

2. To maximize the long-term value of the Corporation to the Treasury of the United States.

3. To lease Department uranium enrichment facilities, as needed.

4. To acquire uranium for uranium enrichment, low-enriched uranium for resale, and highly enriched uranium for conversion into low-enriched uranium, as needed.

5. To market and sell its enriched uranium and uranium enrichment and related services to-

A. the Department for governmental purposes; and

B. domestic and foreign persons, as provided in Section 1303(6).

6. To conduct research and development as required to meet business objectives for the purposes of identifying, evaluating, improving, and testing alternative technologies for uranium enrichment.

7. To conduct the business as a self-financing corporation and eliminate the need for Federal Government appropriations or sources of Federal financing other than those provided in this title. 
8. To help maintain a reliable and economical domestic source of uranium enrichment services.

9. To comply with the laws, and regulations promulgated thereunder, to protect the public health, safety, and the environment.

10. To continue at all times to meet the objectives of ensuring the Nation's common defense and security, including abiding by United States laws and policies concerning special nuclear materials and nonproliferation of atomic weapons and other nonpeaceful uses of atomic energy.

11. To take all other lawful actions in furtherance of these purposes.

In order to accomplish its purposes, the Corporation-...

4. shall enrich uranium, provide for uranium to be enriched by others. or acquire enriched uranium (including low-enriched uranium derived from highly enriched uranium provided under section 1408);

5. may conduct, or provide for conducting, those research and development activities related to uranium enrichment and related processes and activities the Corporation considers necessary or advisable to maintain the Corporation as a commercial enterprise operating on a profitable and efficient basis;

6. may enter into transactions regarding uranium, enriched uranium, or depleted uranium with-
A. persons licensed under section $53,63,103$, or 104 in accordance with the licenses held by those persons;
B. persons in accordance with, and within the period of, an agreement for cooperation arranged under section 123; or
C. persons otherwise authorized by law to enter into such transactions;

7. may enter into contracts with persons licensed under sections 53, 63, 103, or 104 , for as long as the Corporation considers necessary or desirable, to provide uranium or uranium enrichment and related services;

8. may enter into contracts to provide uranium or uranium enrichment and related services in accordance with, and within the period of, an agreement for cooperation arranged under section 123 or as otherwise authorized by law; and

9. shall sell to the Department as provided in this title, without regard to section $57 \mathrm{e}$, the amounts of uranium enrichment and related services that the Department determines from time to time are required for it to- 

A. carry out Presidential directions and authorizations under section 91; and
B. conduct other Department programs.

For purposes of this report, it has been assumed that DOE will retain responsibility for all depleted uranium hexafluoride generated and in storage at the GDPs prior to July 1. 1993. Therefore, this study uses the total DU inventory at the GDPs as of June 30,1992, of $361,000 \mathrm{MTU}$ (i.e., 534,000 MT of $\mathrm{UF}_{6}$ corresponding to $426,000 \mathrm{MT}$ of $\mathrm{U}_{3} \mathrm{O}_{8}$ after conversion-see Chapter 2), as a basis for the study cases. However, since the details of the transition of uranium enrichment responsibilities are still being negotiated, the DU quantities used in this report should be considered preliminary figures for establishing baseline projections. Future negotiations between DOE and the Corporation may involve the sale of part of DOE's DU inventory to the Corporation for enrichment purposes.

\subsubsection{The Clean Air Act}

The Clean Air Act of 1970, as amended (CAA--Public Law 91-604. 42 U.S.C 7401 et seq.), federalized air pollution control regulations and made human health protection the basis for much of that regulation. The Act was amended significantly in 1977 and again in 1990. Title I of the Act regulates "stationary sources" (e.g., treatment and disposal facilities), while Titles II and III regulate "mobile sources" and "citizens suits/judicial review standards", respectively. The primary elements of the CAA that apply to the disposal of the DOE DU are contained in Part A $\S 112$, National Emission Standards of Hazardous Air Pollutants (NESHAP), and Part C $\S \S 160-165$ Prevention of Significant Deterioration (PSD) and Permit to Construct (PTC).

The NESHAP standards for emissions of radionuclides other than radon from DOE facilities are codified in 40 CFR Subpart $\mathrm{H} \S 61.92$. This standard states that "emissions of radionuclides to the ambient air from DOE facilities shall not exceed those amounts that would cause any member of the public to receive in any year an effective dose equivalent of $10 \mathrm{mrem} / \mathrm{yr}$." The NESHAP limit for radon emissions from DOE facilities is $20 \mathrm{pCi} / \mathrm{m}^{2}-\mathrm{s}$ of radon- 222 as an average for the entire source [Subpart Q § 61.192].

\subsubsection{The National Environmental Policy Act}

The National Environmental Policy Act (NEPA) of 1969, as amended (NEPA-Public Law 91-190, 42 U.S.C. 4321 et seq.), established procedures to ensure that information on environmental consequences of proposed actions is available to public officials and citizens before decisions are made to proceed with implementation of said actions. For all proposed major federal actions significantly affecting the quality of the human environment, NEPA calls for a process focusing on preparation of an environmental impact statement (EIS) and on review and comments by the public and by government agencies. Specifically, $\S 102(2)(c)$ of the Act specifies that for major federal actions that may affect the quality of the human environment, the responsible official shall prepare a detailed statement on:

the environmental impact of the proposed action, 
any adverse environmental effects that cannot be avoided should the proposal be implemented,

alternatives to the proposed action,

the relationship between local short-term uses of man's environment and the maintenance and enhancement of long-term productivity, and

any irreversible and irretrievable commitments of resources that would be involved in the proposed action should it be implemented.

Prior to making any detailed statement, the responsible Federal official shall consult with and obtain the comments of any Federal agency that has jurisdiction by law or special expertise with respect to any environmental impact involved. Copies of such statement and the comments and views of the appropriate Federal, State, and local agencies, that are authorized to develop and enforce environmental standards, shall be made available to the President, the Council on Environmental Quality and to the public.

The Council on Environmental Quality's regulations implementing NEPA are contained in 40 CFR Parts 1500-1508. Section 1500.2 establishes the policy that Federal agencies shall to the fullest extent possible:

1. Interpret and administer the policies, regulations, and public laws of the United States in accordance with the policies set forth in the Act and these regulations.

2. Implement procedures to make the NEPA process more useful to decision makers and the public; to reduce paperwork and the accumulation of extraneous background data; and to emphasize real environmental issues and alternatives. Environmental impact statements shall be concise, clear, and to the point, and shall be supported by evidence that agencies have made the necessary environmental analyses.

3. Integrate the requirements of NEPA with other planning and environmental review procedures required by law or by agency practice so that all such procedures run concurrently rather than consecutively.

4. Encourage and facilitate public involvement in decisions which affect the quality of the human environment.

5. Use the NEPA process to identify and assess the reasonable alternatives to proposed actions that will avoid or minimize adverse effects of these actions upon the quality of the human environment.

6. Use all practicable means, consistent with the requirements of the Act and other essential considerations of national policy, to restore and enhance the quality of the human environment and avoid or minimize any possible adverse effects of their actions upon the quality of the human environment. 
For this study, costs for preparation of the required environmental documentation have been included in Chapter 6.

\subsection{Disposal Regulations}

This section describes the DOE orders and NRC regulations currently applicable to DU disposal. The DOE orders are primarily integrated into DOE disposal site operations through their site-specific WAC requirements and radiological performance assessments. The radiological performance assessments for DOE disposal sites discussed in this report are still in the draft phase, although some changes have already been incorporated into their WAC requirements based upon preliminary results of the performance assessments. When these performance assessments are finalized and approved, additional changes can be expected in the site-specific WAC requirements. NRC regulations are applicable to commercial disposal sites and are largely reflected in the radioactive materials licenses for such sites.

The following sections discuss the general requirements specified in DOE orders and NRC regulations. The site-specific requirements that are in place to comply with these orders and regulations are discussed for each individual disposal site in Chapter 5.

\subsubsection{DOE Orders/Policies}

Depleted uranium, if ever declared a waste, would currently be classified as low-level waste (see Section 4.1.2). Disposal within a DOE low-level waste facility would be subject to DOE Order 5820.2A, Chapter III. As prescribed in this DOE Order, the disposal technology is required to meet the following performance objectives (specified under paragraph $3 \mathrm{a}$ ):

1. Protect public health and safety in accordance with standards specified in applicable EH orders and other DOE orders.

2. Assure that external exposure to the waste and concentrations of radioactive material that may be released into the surface water, ground water, soil, plants and animals results in an effective dose equivalent that does not exceed $25 \mathrm{mrem} / \mathrm{yr}$ to any member of the public. Releases to the atmosphere shall meet the requirements of 40 CFR 61 . Reasonable effort should be made to maintain releases of radioactivity in effluents to the general environment as low as is reasonably achievable.

3. Assure that the committed effective dose equivalents received by individuals who inadvertently may intrude into the facility, after the loss of active institutional control (100 years), will not exceed 100 mrem per year for continuous exposure or 500 mrem for a single acute exposure.

4. Protect ground water resources, consistent with Federal, State, and local requirements. 
Additionally, DOE 5820.2A, Chapter III, specifies that DOE disposal sites must maintain a site-specific radiological performance assessment demonstrating compliance with these performance objectives (under paragraph $3 \mathrm{~b}$ ) as follows:

1. Field organizations with disposal sites shall prepare and maintain a site-specific radiological performance assessment for the disposal of waste for the purpose of demonstrating compliance with the performance objectives stated in paragraph $3 \mathrm{a}$.

2. Each field organization shall, for each DOE reservation within its cognizance, prepare and maintain an overall waste management systems performance assessment supporting the combination of waste management practices used in generation reduction, segregation, treatment, packaging, storage, and disposal.

3. Where practical, monitoring measurements to evaluate actual and prospective performance should be made at locations as required, within and outside each facility and disposal site. Monitoring should also be used to validate or modify the models used in performance assessments.

The preceding requirements and specifications are generally reflected in the WAC prepared by each DOE disposal site in accordance with paragraph 3d of DOE 5820.2A, Chapter 3, as follows:

1. Waste shipped from one field organization to another for treatment, storage, or disposal shall be done in accordance with the requirements established by the operations office having responsibility for operations of the receiving facility.

2. Waste acceptance criteria shall be established for each low-level waste treatment, storage, and disposal facility, and submitted to the cognizant field organization.

3. Generators of waste shall implement a low-level waste certification program to provide assurance that the waste acceptance criteria for any low-level waste treatment. storage, or disposal facility used by the generator are met. Generators and facilities receiving the waste are jointly responsible for assuring compliance with waste acceptance criteria. Generators are financially responsible for actions required due to nonconformance.

4. Generator low-level waste certification programs shall be subject to a periodic audit by operators of facilities to which the waste is sent by the generator.

5. The waste acceptance criteria for storage, treatment, or disposal facilities shall address the following issues:

A. Allowable quantities/concentrations of specific radioisotopes to be handled, processed, stored or disposed of;

B. Criticality safety requirements (waste forms and geometries);

C. Restrictions regarding low-level waste classified for security reasons;

D. External radiation and internal heat generation; 
E. Restrictions on the generation of harmful gases, vapors, or liquids in waste;

F. Chemical and structural stability of waste packages, radiation effects, microbial activity, chemical reactions, and moisture;

G. Restrictions for chelating and complexing agents having the potential for mobilizing radionuclides; and

H. Quantity of free liquids.

The DOE orders that ensure compliance with the procedural provisions of NEPA are as follows:

DOE 5400.1, General Environmental Protection Program of 11-9-88, which establishes environmental protection program requirements, authorities, and responsibilities for DOE facilities to assure compliance with all applicable Federal, State, and local environmental protection laws and regulations.

- Secretary of Energy Notice SEN-15-90, National Environmental Policy Act. of 2-5-90, which expresses certain Secretarial policies and goals, and commits DOE to full compliance with NEPA.

- 10 CFR Part 1021, DOE National Environmental Policy Act Implementing Procedures (DOE NEPA Regulations), which establish Departmental procedures for implementing the procedural provisions of NEPA pursuant to 40 CFR Parts 1500-1508. These regulations were published on April 24, 1992, (57 FR 15122) and became effective on May 26, 1992.

- DOE 5440.1E, National Environmental Policy Act Compliance Program of 11-10-92, which establishes DOE responsibilities and procedures to implement the National Environmental Policy Act of 1969.

DOE 5400.5, Radiation Protection of the Public and the Environment, contains the primary DOE standards for the protection of members of the public. This Order replaces DOE 5480.1A and incorporates standards derived from the EPA in 40 CFR 61 (National Emissions Standards for Hazardous Air Pollutants), and 40 CFR 141 (National Interim Primary Drinking Water Standards). The performance objectives of DOE 5400.5 are as follows:

Routine DOE activities shall not cause any individual member of the public to receive, in a year, an effective dose equivalent greater than $100 \mathrm{mrem}$. These limits apply for all exposure modes.

. The airborne effluent pathway shall not result in any member of the public receiving, in a year, an effective dose equivalent greater than 10 mrem (40 CFR 61).

- An annual effective dose equivalent of no more than 4 mrem shall be received by any person through ingestion of water from a drinking water supply operated by or for DOE (40 CFR 141). 
- Radioactive materials in liquid effluents released from DOE facilities shall not cause public or private drinking water systems downstream of the facility discharge to result in any member of the public receiving an annual dose equivalent exceeding $4 \mathrm{mrem}$ to the whole body or to any organ (40 CFR 141).

\subsubsection{NRC Regulations}

NRC regulations are published under 10 CFR Parts 0 to 199 . The DOE and its prime subcontractors are, in most instances, exempt from the requirements for a license [10 CFR $\S \S 30.12,40.11$, and 70.11]. Disposal of DU/low-level radioactive waste by the DOE at its own facility would, therefore, not be subject to NRC licensing. However, disposal of DOE's DU at a commercial facility would be subject to the NRC requirements imposed on the facility as a licensee. (Licensee is used to refer to the holder of a radioactive materials license issued by either the NRC or an "Agreement State" delegated authority by the NRC.)

Regulations in 10 CFR 61 establish the procedures, criteria, and terms and conditions upon which the NRC issues licenses for the land disposal of radioactive wastes containing byproduct. source, and special nuclear material received from other persons. (Disposal of waste by an individual licensee is addressed under 10 CFR 20.) Per 10 CFR $\S 61.59$, disposal of radioactive waste received from other persons is permitted only on land owned in fee by the Federal or a State government. An application to receive, possess, and dispose of wastes containing or contaminated with source, byproduct, or special nuclear material by land disposal must contain the information specified in 10 CFR 61, Subpart B, including sections on general information, specific technical information, institutional information, and financial information. An environmental report (i.e., EIS) prepared in accordance with 10 CFR 51, Subpart A, must also accompany the application. Part 51 contains NRC's regulations and procedures for complying with $\S 102(2)$ of the NEPA.

Extensive technical analyses, including pathway analysis, inadvertent intruder protection analysis, worker protection analysis, and long-term disposal site stability analysis, are required in the permit application to demonstrate that the disposal facility will meet the Commission's performance objectives. The technical analyses must demonstrate that the land disposal facility will be sited, designed, operated, closed, and controlled after closure so that exposures to humans are within the limits specified below:

Concentrations of radioactive material that may be released to the general environment in ground water, surface water, air, soil, plants, or animals must not result in an annual dose exceeding an equivalent of $25 \mathrm{mrem}$ to the whole body, $75 \mathrm{mrem}$ to the thyroid, and $25 \mathrm{mrem}$ to any other organ of any member of the public (10 CFR § 61.41).

Design. operation, and closure of the land disposal facility must ensure protection of any individual inadvertently intruding into the disposal site and occupying the site or contacting the waste at any time after active institutional controls over the disposal site are removed (10 CFR § 61.42). 
- Operations at the land disposal facility must be conducted in compliance with the standards for radiation protection set out in 10 CFR 20. except for releases of radioactivity in effluents from the land disposal facility, which shall be governed by 10 CFR § 61.41 (10 CFR § 61.43).

- The disposal facility must be sited, designed, used, operated, and closed to achieve long-term stability of the disposal site and to eliminate, to the extent practicable, the need for ongoing active maintenance of the disposal site following closure so that only surveillance, monitoring, or minor custodial care are required. (10 CFR § 61.44)

If the application is approved, a radioactive materials license is issued, which in most cases specifies maximum quantities or concentrations of radioactive materials allowed in the waste and conditions for authorized use; packaging; waste form; receipt, acceptance, and inspection of waste; burial operations; site design and construction; environmental monitoring and surveying; and financial assurances.

Disposal of DOE's DU in a commercial low-level waste disposal facility would, therefore, have to satisfy all conditions and requirements specified in the facility's license. However, as discussed in Section 5.2, the availability of commercial disposal sites to DOE waste is extremely limited based upon current conditions. 


\section{DISPOSAL STUDY CASES INVESTIGATED}

This chapter presents information on the current status of the disposal options/sites that were investigated. Attention was primarily focused on existing disposal facilities within the DOE complex and the commercial sector.

\subsection{DOE Disposal Sites}

Descriptions of two DOE disposal facilities, the Nevada Test Site and the Hanford Site, are given in this section. Emphasis has been placed on the NTS because its economic and hydrogeologic factors are more favorable than those of the Hanford Site. Information on the Hanford Site has been included for comparison, and to allow for the possibility that political/regulatory issues may arise at either of the DOE sites. Detailed disposal cost data are presented in Chapter 6 for both the NTS and the Hanford Site.

\subsubsection{Nevada Test Site}

Information presented in this section on the NTS low-level waste disposal areas was primarily obtained from the following four sources:

- Site Book for Waste Management, Reynolds Electrical and Engineering Co, Inc., December $1991 .^{9}$

- Radiological Performance Assessment, U3ah/at Low-Level Waste Disposal Unit, Nevada Test Site, Revision 1, Oak Ridge National Laboratory Pollutant Assessments Group (Grand Junction, CO), September 1991. ${ }^{10}$

- Radiological Performance Assessment for the Area 5 Radioactive Waste Management Site at the Nevada Test Site, Revision 1, EG\&G Idaho, Inc., February 1992."1

Nevada Test Site Defense Waste Acceptance Criteria, Certification, and Transfer Requirements, NVO-325 (Rev. 1), DOE Nevada Field Office (DOE/NV) and Reynolds Electrical \& Engineering Co., Inc., June 1992. ${ }^{12}$

\subsubsection{NTS Description}

The NTS is a DOE nuclear weapons testing facility on approximately 1,350 square miles of federally-owned land in southeastern Nevada's Nye County (see Figure 1). The NTS is situated about 65 miles northwest of Las Vegas. The site is bordered to the west, north, and east by Nellis Air Force Range, a restricted-access, government-owned area. Since it was established in 1952, the primary mission of the NTS has been to serve as a proving ground for the testing and development of nuclear weapons. Through 1987, there were in excess of 685 announced nuclear detonations at the NTS. All tests conducted at the NTS since late 1962 have been below ground, with a total of 84 tests conducted at land surface prior to 1963 . This extensive testing of nuclear weapons has created significant amounts of radioactive materials at various depths beneath the land surface and some residual radioactive material at land surface. 


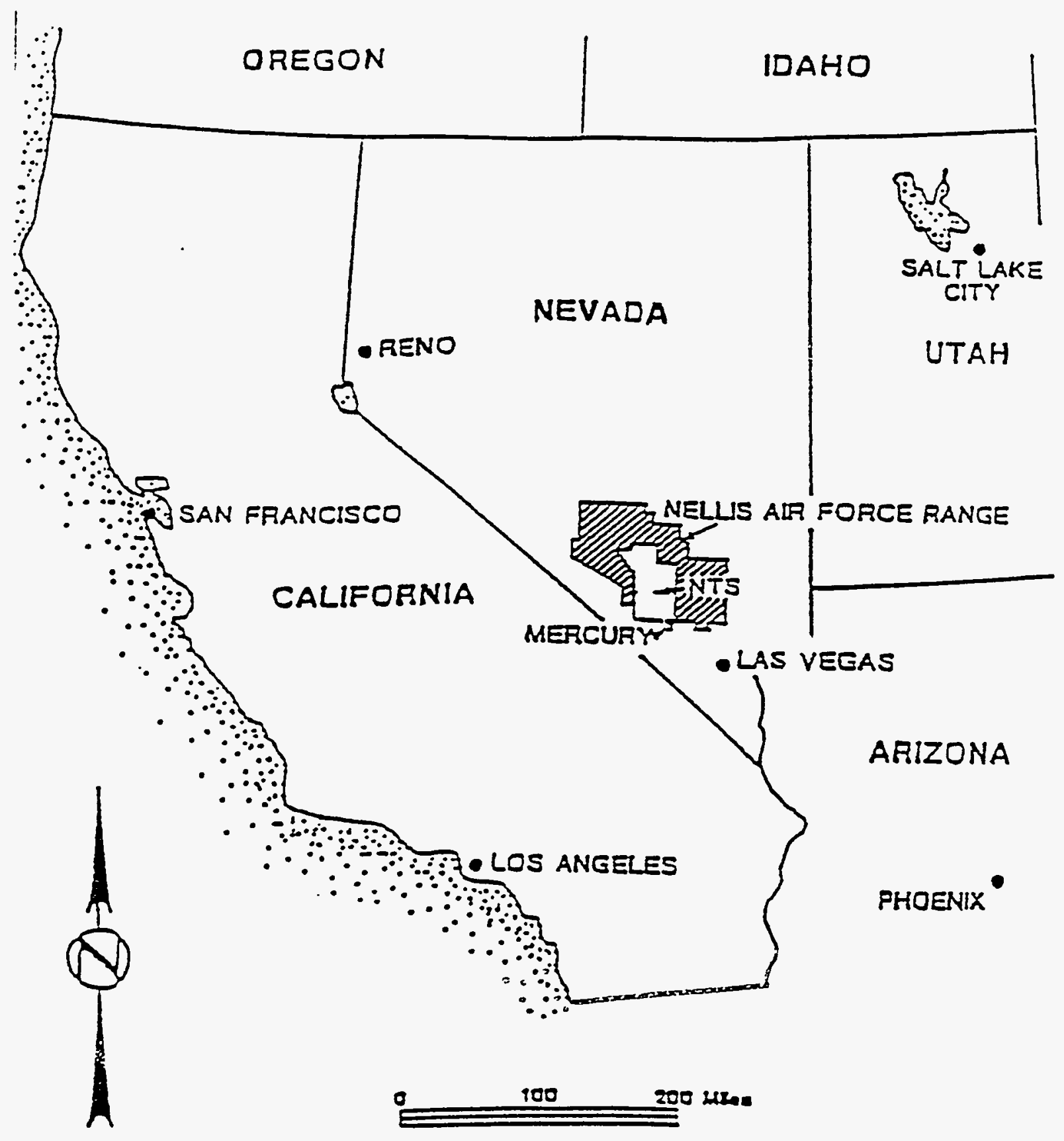

Figure 1. General Location Map of the Nevada Test Site (DOE 1989) 
Waste management activities were initiated in 1961 to dispose of low-level waste produced by the DOE weapons testing program. Disposal activities have expanded from the original burial of atmospheric weapons testing debris, and today the NTS serves as a major disposal facility for low-level radioactive waste generated by numerous installations throughout the DOE complex. Other operations include a storage facility for transuranic waste from Lawrence Livermore National Laboratory, development of a mixed waste management unit, and collection of NTS-generated hazardous waste for disposal. These operations are administered by the DOE Nevada Field Office, and performed by Reynolds Electrical \& Engineering Co., Inc. (REECo), Waste Management Department (WMD). There are two principal defense waste management sites at the NTS-the Area 5 Radioactive Waste Management Site (RWMS) and the Area 3 RWMS (see Figure 2). Descriptions of both disposal areas are provided below, as they currently exist. NTS personnel indicate that disposal of DOE's DU would likely take place in dedicated trenches/craters within these areas. ${ }^{f}$

Area 5. The Area 5 RWMS is located in the southeastern portion of the NTS about 13 miles north of Mercury, NV, on the northern area of Frenchman Flat. Frenchman Flat is one of the three main desert basins on the NTS, consisting of an oval-shaped basin with a large dry lake bed in the center with no external drainage for water. Average daily temperatures range from $2{ }^{\circ} \mathrm{C}$ in January to $24^{\circ} \mathrm{C}$ in August. Valley floors such as Frenchman Flat average about 4 in. of precipitation per year. The top of the alluvial aquifer is approximately $770 \mathrm{ft}$ below land surface.

The Area 5 RWMS encompasses a total of 732 acres on the Frenchman Flat. The Low-Level Waste Management Unit (LLWMU) comprises 92 acres in the southeast corner of the RWMS. The LLWMU contains two types of disposal cells: (1) shallow land disposal trenches and pits for low-specific-activity waste, and (2) greater confinement disposal (GCD) boreholes for high-specific-activity waste. The majority of the low-level waste disposed at the existing facilities consists of contaminated laboratory waste, soil, process waste, and construction debris. Common radioactive constituents of this waste are depleted and enriched uranium, mixed fission products, high-specific-activity tritium, and transuranics at less than $100 \mathrm{nCi} / \mathrm{g}$ concentrations. The total volume of low-specific activity waste disposed of in pits and trenches through 1990 consisted of approximately 5.3 million $\mathrm{ft}^{3}$ and 4.2 million $\mathrm{Ci}$ (undecayed). Most of the waste is buried in 55-gallon metal drums and plywood boxes. An additional 4,600 $\mathrm{ft}^{3}$ and 2.9 million $\mathrm{Ci}$ of high-specific-activity waste were disposed of in the GCD boreholes.

Currently, Pit 4 and Trenches 2, 3, and 8 of Area 5 are open to accept waste. Pit 4 accepts low-level waste and is $1,000 \mathrm{ft}$ long, $200 \mathrm{ft}$ wide, and $20 \mathrm{ft}$ deep, with an initial capacity of $3,200,000 \mathrm{ft}^{3}$ and a remaining capacity of $1,536,000 \mathrm{ft}^{3}$ (as of early 1992). Trench 2 is used for classified waste and is approximately $254 \mathrm{ft}$ long, $60 \mathrm{ft}$ wide, and $205 \mathrm{ft}$ deep, with an initial capacity of $243,840 \mathrm{ft}^{3}$ and a remaining capacity of $157,143 \mathrm{ft}^{3}$. Trench 3 is approximately $630 \mathrm{ft}$ long, $45 \mathrm{ft}$ wide, and $15 \mathrm{ft}$ deep, with a capacity of $314,138 \mathrm{ft}^{3}$. Trench 8 is reserved for

f. Gene Kendall, Manager REECo Waste Management Department, Personal Communication with Doug Nishimoto, SAIC, January 26, 1993. 


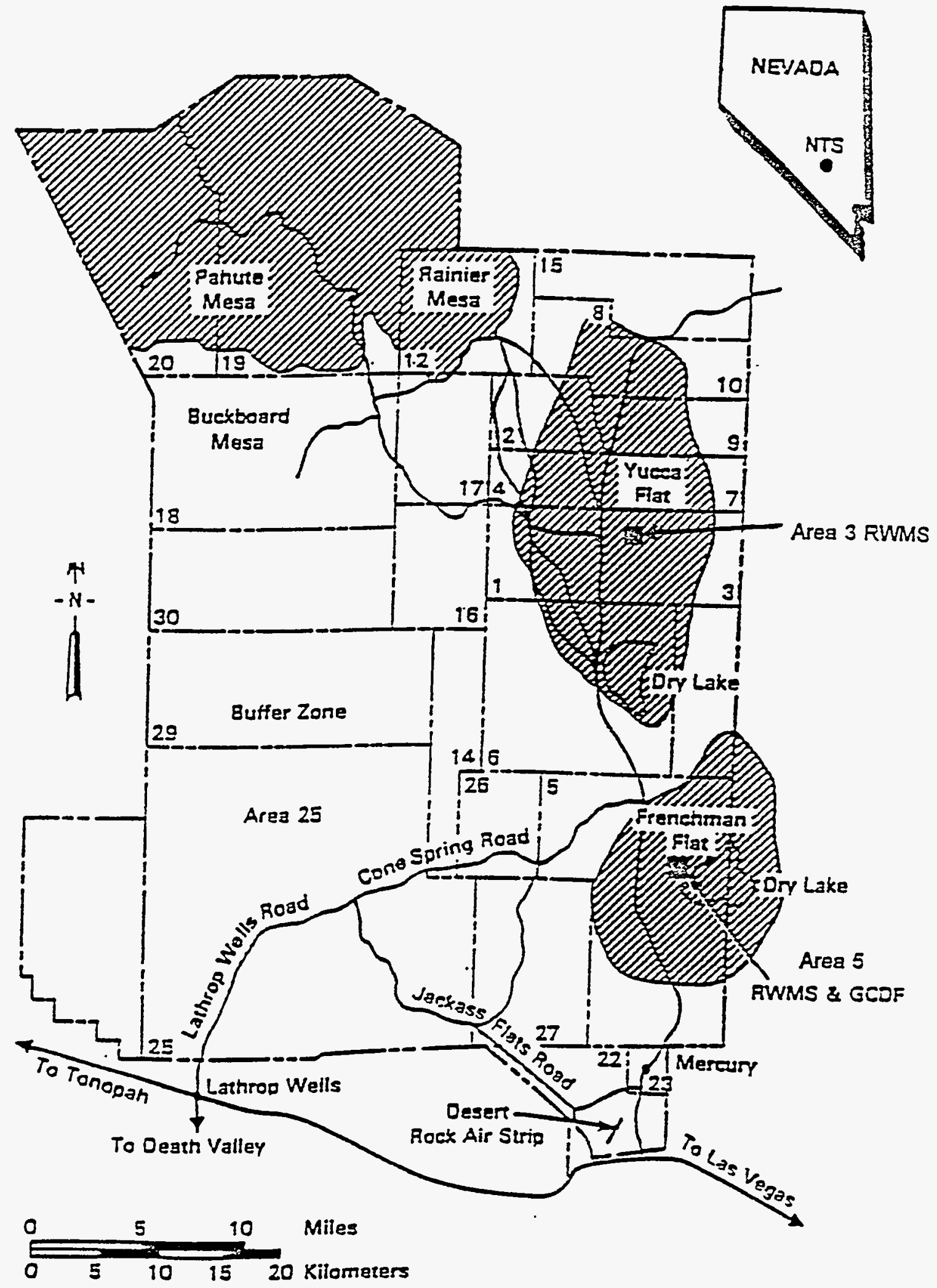

Figure 2. Radioactive Waste Management Sites 
future thorium/low-level waste and is approximately $6.320 \mathrm{ft}$ long, $100 \mathrm{ft}$ wide, and $24 \mathrm{ft}$ deep. with a capacity of $1,008,000 \mathrm{ft}^{3}$.

Pit 4 of Area 5 is used for the disposal of low-level waste from currently approved generators. Pit 4 was opened June 21, 1988 and as of early 1992 was approximately one-half full. The waste is stacked by weight with the heaviest packages on the bottom and the lightest on top. Waste is stacked within four ft of the original land surface and then covered with approximately $8 \mathrm{ft}$ of natural soil.

Area 3. The Area 3 RWMS is located on Yucca Flat in the northeastern section of NTS (about 21 miles north of Mercury, NV) and covers an area of approximately 50 acres. At Yucca Flat, the average annual daily minimum temperature is $3{ }^{\circ} \mathrm{C}$, and the average annual daily maximum temperature is $22^{\circ} \mathrm{C}$. The mean annual rainfall is approximately 7 in. Depth to the water table is approximately $1,600 \mathrm{ft}$.

Yucca Flat has been used extensively for testing nuclear weapons. Subsidence craters resulting from these tests have been primarily used for the disposal of bulk low-level waste. Use of the Area 3 RWMS started around 1980 when the Waste Consolidation Project began with the primary objective of cleaning up radioactively contaminated debris from aboveground nuclear tests from 24 debris disposal sites. Packaged bulk low-level waste from offsite DOE facilities has also been buried here. The subsidence craters are selected for disposal cells based upon site geology and the depth at which the nuclear device was detonated. Area 3 RWMS waste management cells are comprised of two adjacent subsidence craters, with the area between the two craters excavated to make one large, oval-shaped landfill cell. To date, all disposal operations have taken place in four craters, U3ax, U3bl, U3ah, and U3at. The U3ax/bl craters were used to dispose of consolidated waste from the Atmospheric Testing Debris Disposal Program until the craters were closed in 1987.

Disposal operations at the U3ah/at craters began in 1988 and the craters are currently being used for consolidated waste and packaged bulk LLW from offsite. The U3ah crater resulted from a test detonation at a burial depth of $1191 \mathrm{ft}$ in December 1961; it is $49 \mathrm{ft}$ deep. $600 \mathrm{ft}$ in diameter, and has a volume of approximately 13.8 million $\mathrm{ft}^{3}$. The U3at crater resulted from a test detonation $987 \mathrm{ft}$ below the surface in March 1963 and is $78.5 \mathrm{ft}$ deep, $610 \mathrm{ft}$ in diameter, and has a volume of approximately 22.9 million $\mathrm{ft}^{3}$. The entire U3ah/at disposal site is surrounded by a $39-\mathrm{ft}$ wide by $4-\mathrm{ft}$ high earthen runoff control dike.

Currently, waste disposed at U3ah/at is in nonstandard containers such as sea-land containers and bales or in bulk form. During disposal operations, each subsidence crater is divided into waste tiers. Each waste tier is about $8 \mathrm{ft}$ high and is covered with about $3 \mathrm{ft}$ of clean fill before the next tier is started. Seven tiers of waste are planned for disposal, with the seventh tier covered with $4.5 \mathrm{ft}$ of soil to bring the disposal crater to grade before the closure cap is emplaced. The multilayered cover will consist of a backfill layer, a low permeability layer, a biointrusion layer to impede the intrusion of plants and animals, a rooting layer to support vegetation, and a final layer of gravel mulch and native vegetation. 


\subsubsection{NTS Waste Acceptance Criteria}

The DOE/Nevada Field Office establishes radioactive waste acceptance criteria and requirements for waste certification, characterization, and transfer for all wastes received for disposal at the NTS, in either Area 3 or Area 5. These requirements are contained in the Nevada Test Site Defense Waste Acceptance Criteria, Certification, and Transfer Requirements. NVO-325, Revision $1 .^{12}$

Prior to new off-site generators being considered for shipping waste to the NTS, they must contact DOE headquarters to obtain an official written designation of the waste as defense waste. Once official designation is obtained, off-site generators must then contact the DOE/NV Manager for approval to submit an application to ship waste to the NTS. This application form consists of six main parts: generator information, waste characterization program, waste stream information, waste certification program, exemption requests, and procedures and supporting documentation. If an application is found to be adequate by DOE/NV, an audit will be scheduled and the application review comments will be discussed during that audit. Waste stream approval will be granted after the generator has demonstrated compliance with any audit findings and any necessary revisions to the application have been made.

The following WAC requirements are specified in Section 5.5 of NVO-325 for LLW:

1. The package closure (e.g., metal clips or banding) must be sturdy enough that it will not be breached under normal handling conditions and will not serve as a weak point for package failure.

2. LLW disposed at the NTS shall contain as little free liquids as is reasonably achievable, but in no case shall the liquid equal or exceed 0.5 percent by volume of the external waste container. Absorbent will be added as a precautionary measure to absorb any moisture that may form due to condensation attributed to the variations in temperature and humidity from state-of-generation to NTS. Packages will also be reviewed by real-time radiography prior to package certification.

3. LLW must have a transuranic nuclide concentration less than $100 \mathrm{nCi} / \mathrm{g}$. The mass of the waste container, including shielding, shall not be used in calculating the specific activity of the waste.

4. LLW offered for disposal at NTS shall not exhibit any characteristics of, or be listed as, hazardous waste as identified in 40 CFR 261 or state-of-generation hazardous waste regulations.

5. Fine particulate wastes shall be immobilized so that the waste package contains no more than 1 weight percent of less-than-10-micrometer-diameter particles, or 15 weight percent of less-than-200-micrometer-diameter particles. Waste that is known to be in a particulate form or in a form that could mechanically or chemically be transformed to a particulate during handling and interim storage shall be immobilized. When immobilization is impractical, other acceptable waste packaging shall be used such as: overpacking (i.e., 55-gallon drum inside 83- or 85-gallon 
drum), steel box with no liner, wooden box with a minimum of 6-mil sealed plastic liner, or steel drum with a minimum of 6-mil sealed plastic liner.

6. LLW gases shall be stabilized or absorbed so that the pressure in the waste package does not exceed 1.5 atmospheres at $20^{\circ} \mathrm{C}$.

7. Where practical, waste shall be treated to reduce volume, promote waste minimization, and provide a more structurally and chemically stable waste form. Structural stability can be accomplished by crushing, shredding, or placing a smaller piece inside an opening of a larger piece, such as nesting pipes. Chemical stability must be documented to show that significant quantities of harmful gases, vapors, or liquids are not generated. Wastes shall not react with the packaging during storage, shipping, and handling time. Where stabilization is required for the waste to meet this waste acceptance criteria, it must be shown that the stabilization process is adequately controlled.

8. LLW containing pathogens, infectious wastes, or other etiologic agents as defined in 49 CFR $\S 173.386$ will not be accepted for disposal at NTS.

9. LLW containing chelating or complexing agents at concentrations greater than 1 percent by weight of the waste form will not be accepted.

10. PCB-contaminated LLW will not be accepted for disposal at NTS unless the PCB concentration meets municipal solid waste disposal levels of $50 \mathrm{ppm}$ or less.

11. LLW containing explosive and/or pyrophoric material in a form that may spontaneously explode or combust, if the container is breached, will not be accepted.

12. Defense waste shipped to NTS must be packaged in accordance with all DOE and DOT regulations, including DOE Order 1540.1, Materials Transportation and Traffic Management; 49 CFR $\S 173.448$, General Transportation Requirements; 49 CFR $\S 173.474$, Quality Control for Construction of Packaging; and 49 CFR $\S 173.475$, Quality Control Requirements Prior to Each Shipment of Radioactive Materials. Type A packaging shall be designed to meet 49 CFR $\S 173.411$, General Design Requirements, and 49 CFR $\S 173.412$, Additional Design Requirements for Type A Packages. Type A packages must have been evaluated under the DOE Type A package Certification Program. Type B packaging must meet the applicable requirements of $10 \mathrm{CFR}$ 71. Strong, tight packaging used for shipping limited quantities and low specific activity LLW excepted by 49 CFR $\S \S 173.421$ and 173.425 , respectively, must be constructed so that it will not leak during normal transportation and handling conditions.

13. The quantity of fissile radioactive materials shall be limited so that an infinite array of such packages will remain subcritical. This quantity shall be determined on the basis of a specific nuclear safety analysis, considering credible accident situations, and 
taking into account the actual materials in the waste. See 49 CFR $\S 173.451$, Fissile Materials - General Requirements.

14. The quantity of radioactive materials shall be limited for each waste matrix and package type so that the effects of nuclear decay heat will not adversely affect the physical or chemical stability of the contents or package integrity.

15. The external radiation levels for packages shall not exceed $200 \mathrm{mrem} /$ hour on contact during handling, shipment, and disposal unless specifically excepted by DOT regulations. See 49 CFR $\S 173.441$, Radiation Level Limitations. Type B containers that will be unloaded by remote procedures will be addressed on a case-by-case basis. Packages shall be within DOT contamination limits upon receipt at NTS. See 49 CFR § 173.443, Contamination Control.

16. The activity limits listed in 49 CFR $\S 173.431$, Activity Limits for Type $A$ and Type $B$ Packages, shall be met. Where applicable, the activity limits of 49 CFR $\S 173.421$. Limited Quantities of Radioactive Materials, and 49 CFR $\S 173.425$, Transport Requirements for LSA Radioactive Materials, shall be met for strong, tight packages.

17. Waste containing multiple hazards shall be packaged according to the level of hazard as defined in $49 \mathrm{CFR} \S 173.2$, Classification of Material Having More than One Hazard.

18. Except for bulk waste, waste packaged in steel drums, or SEALAND containers, the waste package (packaging and contents) shall be capable of supporting a uniformly distributed load of $4,000 \mathrm{lb} / \mathrm{ft}^{2}$. This is required to support other waste packages and earth cover without crushing during stacking and covering operations.

19. All waste packages shall be provided with permanently attached skids, cleats, offsets, rings, handles, or other auxiliary lifting devices to allow handling by means of forklifts, cranes, or similar handling equipment. All rigging devices that are not permanently attached to the waste package must have a current load test based on $125 \%$ of the safe working load.

20. $1.2 \times 1.2 \times 2.1-\mathrm{m}(4 \times 4 \times 7-\mathrm{ft}) \quad$ or $1.2 \times 0.6 \times 2.1-\mathrm{m}(4 \times 2 \times 7-\mathrm{ft})$ (width, height, length) boxes or 208-liter (55-gallon) drums are required to be used. Bulk waste containers must be approved by $\mathrm{DOE} / \mathrm{NV}$ and containers of other dimensions are acceptable with approval from DOE/NV on a case-by-case basis.

21. In addition to the weight limits set for specific packaging designs, NTS imposes limits of $4,082 \mathrm{~kg}(9,000 \mathrm{lb})$ per box and $544 \mathrm{~kg}(1,200 \mathrm{lb})$ per 55 -gallon drum. Packages exceeding $9,000 \mathrm{lb}$ require crane or large forklift removal and must be approved by REECo/WMD prior to shipment and must be in a removable-top or removable-side trailer. 
22. Waste packages shall be loaded to ensure that the interior volume is as efficiently and compactly loaded as practical. High density loading will allow efficient RWMS space utilization and provide a more stable waste form that will reduce subsidence and enhance the long-term performance of the disposal site.

23. Use of DOT Type A packages not previously evaluated under the DOE Type A Package Certification Program will not be permitted.

24. The generator's preshipment storage environment shall be controlled to avoid the adverse influence from weather or other factors on the containment capability of the waste packaging during handling, storage, and transport. The generator preparing waste for preshipment storage shall take all reasonable precautions to preclude the accumulation of moisture on or in the packages prior to their arrival at the NTS.

Additional marking, labeling, and bar coding requirements are specified in NVO-325.

Not all of the waste acceptance criteria listed above would be applicable to the $\mathrm{U}_{3} \mathrm{O}_{8}$ form of DU that may eventually be disposed of by DOE. The only specific condition that may greatly impact future disposal of depleted uranium oxide is WAC Number 5, dealing with particulate wastes. One of the assumptions used in this study is that the $\mathrm{U}_{3} \mathrm{O}_{8}$ will be subjected to a compacting/screening/fines recycling operation at the point of conversion so that it will satisfy the waste acceptance particle size criteria, thereby eliminating the need for fixation or packaging in lined containers. An added benefit of the compaction process would be to increase the DU bulk density from $1.4 \mathrm{~g} / \mathrm{cm}^{3}$ (out of the kiln) to about $3 \mathrm{~g} / \mathrm{cm}^{3.2}$ effectively decreasing the disposal volume by a factor of more than two. If the compacted oxide does not meet particle size criteria, NTS personnel have indicated that use of plastic liners within the drums would be sufficient. ${ }^{g}$ This alternative would not greatly impact the containerized volume of DU that would be disposed of at the NTS. and is certainly preferred over immobilization with respect to minimizing waste volumes.

One additional impact of the ongoing site-specific radiological performance assessments being prepared for the Area 3 and Area 5 disposal facilities may be that DU would require burial at depths somewhat greater than currently used or, alternatively, mounding over with a thicker closure cap. ${ }^{\mathrm{h}}$ This may be required to ensure that release of radon gas (which, due to uranium's slow decay rate, becomes a concern only after thousands of years) does not exceed any of the NTS' performance objectives (see Section 4.2.1) for radiological dose limits.

g. Robert L. Dodge, Chief REECo Technical Support Section, Personal Communication with Doug Nishimoto, SAIC, January 27, 1993.

h. F. Tom Lindstrom, REECo Special Projects Section, Personal Communication with Doug Nishimoto, SAIC, March 9, 1993. 


\subsubsection{Hanford Site}

\subsubsection{Hanford Site Description}

The Hanford Site is located on 600 square miles of federally owned land in south central Washington, to the northwest of Richland and between the Yakima and Columbia Rivers (see Figure 3). Most of Hanford's waste handling facilities are located on a plateau in the central portion of the Site, in or near the 200-West and 200-East Areas. ${ }^{13}$ The 200 Area plateau, where most of the radioactive waste is stored, ranges in elevation from about 620 to $800 \mathrm{ft}$ above mean sea level. Average monthly temperatures range from a low of $-1.5^{\circ} \mathrm{C}$ in January to a high of $24.7^{\circ} \mathrm{C}$ in July, while average annual precipitation is about 6.3 inches. The water table (i.e. the upper limit of the unconfined aquifer) ranges from 185 to $330 \mathrm{ft}$ beneath the ground surface. ${ }^{14}$ LLW disposal facilities are located within both the 200 -West and 200-East Areas.

\subsubsection{Hanford Waste Acceptance Criteria}

Westinghouse Hanford Company manages the Hanford Site radioactive solid waste disposal facilities for the DOE/Richland Operations Office. WAC requirements are specified in Hanford Site Solid Waste Acceptance Criteria, WHC-EP-0063-3. ${ }^{15}$

Each waste generator is required to receive formal approval from Westinghouse Hanford Solid Waste Engineering Analysis for the disposal of radioactive solid waste before shipping that waste to the Hanford Site. The process starts with approval of the generator's LLW Certification Plan followed by successful completion of an initial Waste Management Audit by Solid Waste Engineering personnel. Upon completion of the audit, and any necessary action items, the generator will be granted approval or limited approval for shipment of the waste to the Hanford Site. Offsite generators must submit initial requests for a Storage/Disposal Approval Record (SDAR) to the Waste Management Division Director, DOE Operations Office, Richland, through the waste generator's DOE office. Each request to store or dispose of radioactive solid waste must be accompanied by the following information:

- Complete description of the waste or waste stream.

- Complete characterization of all radionuclides and their curie content and chemical data per the approved Waste Certification Plan.

- Complete description of packaging, containers, and returnable transport overpacks (if applicable).

- Evidence demonstrating that waste packages for LLW comply with applicable requirements in Chapter 4 of the Hanford WAC. ${ }^{15}$

Some of the requirements specified in Chapter 4 of the Hanford WAC that are applicable to disposal of DOE's DU include: 


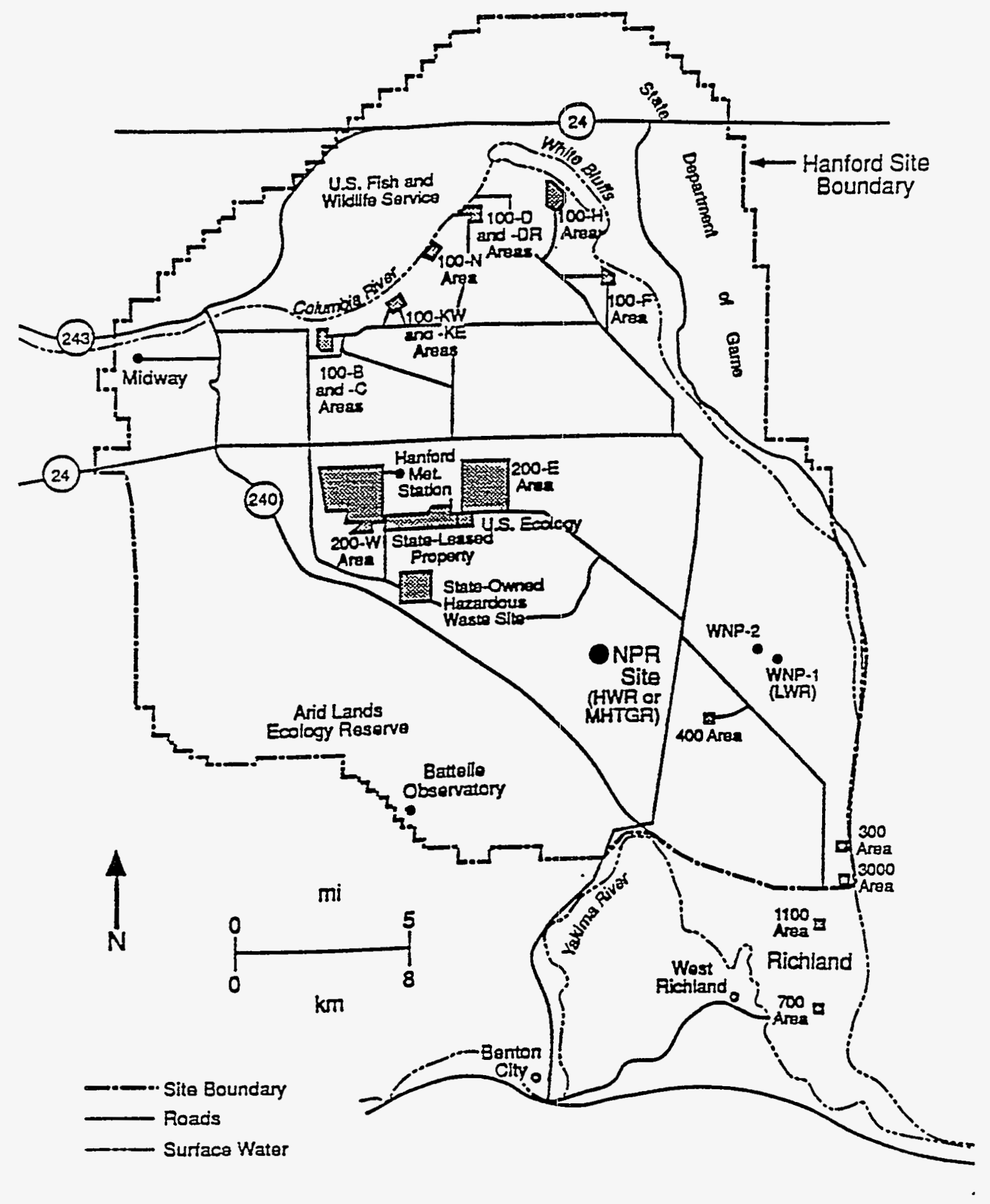

Figure 3. Locations of Existing Facilities at the Hanford Site 
1. As a result of Hanford's preliminary site-specific radiological performance assessment. all LLW must be classified (immediately after generation and before packaging) according to Category 1,3, and greater than Category 3 concentration limits for radioisotopes with half-lives greater than 5 years. For waste containing mixtures of radionuclides, the total concentration shall be determined by the sum of the fractions rule: divide each radionuclide's concentration by the appropriate limit and add the resulting values. Interim Hanford Site waste classifications for LLW are as follows:

Waste Category 1--Low activity waste with very low concentrations of longlived radionuclides. [This waste will not present an unacceptable hazard to an intruder after the active institutional control period (100 years).] If the radionuclide concentration does not exceed the value in Table 4-1, Column 1 of the Hanford WAC, the waste is Category 1.

Waste Category 3--Moderate and high activity waste with low to moderate concentrations of long-lived radionuclides. [This stabilized waste cannot pose an unacceptable hazard to an intruder or public health and safety for a long. as yet unquantified, time period.] If the radionuclide concentration exceeds the value in Table 4-1, Column 1, but does not exceed the value in Table 4-1, Column 2 of the Hanford WAC, the waste is Category 3.

Greater than Waste Category 3 (GTWC3)--Waste that has radionuclide concentrations greater than Category 3 (i.e., exceeds the value in Table 4-1, Column 2 of the Hanford WAC) is not generally acceptable for near-surface disposal and will be called GTWC3 waste to meet the intent of DOE Order 5820.2A. Disposal systems for GTWC3 wastes must be justified by a specific performance assessment. Additional engineered features may need to be incorporated into the design of the system for disposal of the waste. Such disposal system designs shall be supported by appropriate environmental documentation in accordance with the National Environmental Policy Act process and be approved by the cognizant DOE operations office and DOE Headquarters.

It is currently anticipated that Category 3 waste consisting of uranium in any form will require grouting prior to disposal at the Hanford Site, ${ }^{i}$ while GTWC3 waste will require even more extensive engineered features. The applicable concentration limits for DU are presented in Table 9, based upon "draft" values as of February 19, 1993, which have not yet been incorporated into the Hanford WAC.

i. Mark Wood, Westinghouse Hanford, Personal Communication with Doug Nishimoto, SAIC, March 31, 1993.

j. N.P. Willis, Westinghouse Hanford, Draft Table 1. Category 1 and 3 Concentration Limits Based on Intruder Scenarios, Telefax to Doug Nishimoto, SAIC, February 19, 1993. 
Table 9. Proposed Uranium Waste Category Limits at Hanford

\begin{tabular}{ccc} 
& \multicolumn{2}{c}{ Concentration Limits $\left(\mathrm{Ci} / \mathrm{m}^{3}\right)$} \\
Nuclide & Category 1 (Column 1) & Category 3 (Column 2) \\
U-234 & $9.1 \mathrm{E}-03$ & $2.1 \mathrm{E}+00$ \\
U-235 & $3.2 \mathrm{E}-03$ & $5.9 \mathrm{E}-01$ \\
U-238 & $6.3 \mathrm{E}-03$ & $1.4 \mathrm{E}+00$
\end{tabular}

Based upon the reported specific activity of depleted $\mathrm{U}_{3} \mathrm{O}_{8}$ of $0.31 \mu \mathrm{Ci} / \mathrm{g},{ }^{16}$ (compared to the reported specific activity of $0.335 \mu \mathrm{Ci} / \mathrm{g}$ for $\mathrm{DU}^{17}$ ), which translates to $0.93 \mathrm{Ci} / \mathrm{m}^{3}$ using a density of $3 \mathrm{~g} / \mathrm{cm}^{3} .^{2}$ it appears that DOE's DU would qualify as a Class 3 waste and would probably require grouting prior to disposal.

2. All LLW packages accepted for storage (except waste to be compacted) at the Hanford Site facilities shall be packaged in DOT specification $17 \mathrm{H}$ or $17 \mathrm{C}$ steel 55 -gal drums. Drums should, if practical, be banded and palletized in groups of four. Other containers may be approved in the applicable SDAR. Containers used for storage shall be designed to withstand the weight of two layers of 55-gal drums stacked on top with $1,000 \mathrm{lb}$ in each drum.

3. All LLW packages shall provide at least two containment barriers to prevent the release of contamination. Examples of two containment barriers include a plastic bag or a plastic liner inside a steel drum, or a steel drum inside another steel drum. Plastic liners used for primary containment shall be 10 mil, nylon-reinforced plastic.

4. LLW containing free liquids, tritiated waste, asbestos, ion exchange resins, alkali metals, long-term radioactive wastes (may apply to DU, requiring case-by-case evaluation), explosives and compressed gases, pyrophoric materials, animal carcasses, classified waste, or infectious waste must meet specified waste form criteria.

5. Surface dose rates for all packaged waste shall meet requirements of 49 CFR $\S 173.441$. Contact-handled 55-gal drums or smaller packages shall not exceed $200 \mathrm{mrem} / \mathrm{h}$ at any point on the surface. For larger contact-handled packages, normal surface radioactivity shall not exceed $200 \mathrm{mrem} / \mathrm{h}$.

6. Removable contamination on the exteriors of all LLW packages shall not exceed $220 \mathrm{pm} / 100 \mathrm{~cm}^{2}$ for alpha contamination or $2.200 \mathrm{dpm} / 100 \mathrm{~cm}^{2}$ for beta-gamma contamination.

7. Acceptance criteria for any LLW with the potential to generate greater than $0.1 \mathrm{~W} / \mathrm{ft}^{3}$ shall be included in the SDAR. 
8. All LLW with the potential to generate sufficient gas to pressurize the waste package or to reach explosive concentrations of hydrogen and oxygen or other explosive gases shall be vented.

9. The internal void space of any LLW package disposed at the Hanford Site shall not exceed $10 \%$ of the total internal volume of the waste package.

10. Nuclear criticality safety limits for packages containing more than $15 \mathrm{~g}$ of U-235 will be determined by Westinghouse Hanford Criticality Engineering Analysis on a case-by-case basis. Packages containing less than $15 \mathrm{~g}$ of U-235 will not require a separate criticality safety analysis.

\subsubsection{Hanford Site Disposal Costs}

The disposal cost for offsite LLW at the Hanford Site is $\$ 58.70 / \mathrm{ft}^{3}$ of containerized waste volume (as of 2/19/93). ${ }^{k}$ This compares to a 1992 disposal rate of $\$ 76.98 / \mathrm{ft}^{3}$. ${ }^{3}$ Because the Hanford waste classification concentration limits for uranium isotopes have not been finalized, definitive disposal costs cannot currently be determined for DOE's DU. If, in fact, the DU qualifies as either Category 3 waste or GTWC3 waste, additional costs would be incurred.

\subsection{Commercial Disposal Sites}

Three commercial facilities were investigated as potential candidates for the disposal of DOE's depleted uranium:

- US Ecology's Richland, Washington LLW Disposal Facility

· Chem-Nuclear Systems, Inc.'s Barnwell, South Carolina LLW Disposal Facility

- Envirocare's Clive, Utah LLW Disposal Facility.

However, none of the commercial disposal site alternatives were found to warrant further consideration, as discussed below.

US Ecology's Richland LLW Disposal Facility is located on 100 acres of land within the Hanford Site (between the 200-West and 200-East areas) that are leased to the state of Washington. ${ }^{13}$ Disposal rates are averaging about $\$ 44 / \mathrm{ft}^{3}$ (as of $3 / 1 / 93$ ), but have been fluctuating a great deal. The US Ecology facility has been eliminated from further consideration because, as of December 31,1992, it is accepting only wastes generated by states within the Northwest LLW Compact (Alaska, Idaho, Montana, Oregon, Utah, Washington, and Wyoming)

k. N.P. Willis, Westinghouse Hanford, Personal Communication with Doug Nishimoto, SAIC, February 19, 1993.

1. N.P. Willis, Westinghouse Hanford, Personal Communication with Doug Nishimoto, SAIC, September 18, 1992. 
and the Rocky Mountain LLW Compact (Colorado, Nevada, and New Mexico). ${ }^{\mathrm{m}}$ (NOTE: US Ecology's facility in Beatty, Nevada, which formerly served the Rocky Mountain regional compact, closed as of December 31, 1992.)

Chem-Nuclear's Barnwell LLW Disposal Facility is located approximately five miles west of Barnwell, South Carolina, near the eastern boundary of the Savannah River Site on 300 acres of land (184 acres of total burial space) owned by the state of South Carolina. ${ }^{18}$ This facility is the designated disposal site for the Southeast Interstate Low-Level Radioactive Waste Management Compact (Alabama, Florida, Georgia, Mississippi, North Carolina, South Carolina, Tennessee, and Virginia). Current disposal rates at Barnwell are $\$ 60.42 / \mathrm{ft}^{3}$, with a $\$ 34 / \mathrm{ft}^{3}$ surcharge for wastes from states within the southeast compact other than South Carolina, and a $\$ 220 / \mathrm{ft}^{3}$ surcharge for wastes from states outside the southeast compact. ${ }^{\mathrm{n}}$ Thus, the Barnwell facility could conceivably accept DOE's DU at the present time, for about $\$ 280.42 / \mathrm{ft}^{3}$. However, Barnwell is accepting waste external to the southeast compact only until June 30 , 1994. and is scheduled to cease operations as of January $1,1996 .^{\circ}$ As a result, this commercial facility has also been eliminated from further consideration as a potential disposal site for DOE's DU. since disposal of depleted $\mathrm{U}_{3} \mathrm{O}_{8}$ is not expected to occur for at least ten years.

Envirocare's LLW Disposal Facility in Clive, Utah has been eliminated from further consideration because it is limited to the disposal of low activity waste material. The facility's radioactive material license from the Utah Department of Environmental Quality, Division of Radiation Control (License No. UT 2300249) specifies the following maximum concentrations in waste for disposal:

- Uranium-234: $37,000 \mathrm{pCi} / \mathrm{g}$

- Uranium-235: $770 \mathrm{pCi} / \mathrm{g}$

- Uranium-238: $28,000 \mathrm{pCi} / \mathrm{g}$

- Depleted Uranium: $110,000 \mathrm{pCi} / \mathrm{g}$

Since depleted uranium oxide has a specific activity of $310,000 \mathrm{pCi} / \mathrm{g},{ }^{16}$ the Envirocare facility would not currently be able to accept the DU for disposal. No cost data are available for this facility.

m. Gary Young, US Ecology, Personal Communication with Doug Nishimoto. SAIC, March 1, 1993.

n. Jack Harrison, Chem-Nuclear, Personal Communication with Doug Nishimoto, SAIC, February 16, 1993.

o. Tom Kerr, Southeast Compact Manager, EG\&G Idaho National LLW Program, Personal Communication with Doug Nishimoto, SAIC, March 12, 1993. 


\section{DISPOSAL COSTS}

This chapter presents the estimated costs for disposing of the DU as $\mathrm{U}_{3} \mathrm{O}_{8}$ in DOE LLW and RCRA mixed waste (MW) disposal facilities. As discussed in Chapter 4.0, DU, in any form. is not defined as a RCRA waste. However, to establish a worst-case disposal cost estimate. RCRA disposal costs were included as a part of this study. In addition to the cost of disposing the $\mathrm{DU}$ as $\mathrm{U}_{3} \mathrm{O}_{8}$, the costs associated with disposal of calcium fluoride $\left(\mathrm{CaF}_{2}\right)$ are also included. The $\mathrm{CaF}_{2}$ is produced when HF, generated during the $\mathrm{UF}_{6}$ to oxide conversion process, is neutralized. Currently, relatively small quantities of HF produced during the conversion of UF to green salt (i.e., $\mathrm{UF}_{4}$ ) for defense program purposes are recovered and recycled back into the process of converting natural uranium ore into $\mathrm{UF}_{6}$. As discussed further in Section 6.1. the HF is slightly contaminated with uranium and is, therefore, a LLW not releasable to non-nuclear markets. It is assumed for this study that all the HF generated during the conversion process will be neutralized and disposed of as $\mathrm{CaF}_{2}$.

Disposal costs were estimated for both the NTS and the Hanford Site to define a range of present disposal costs at $\mathrm{DOE}$-operated facilities. This range is assumed to represent reasonable lower and upper bounds for costs associated with DU disposal. The range should also allow for increased costs in the future. For example, the current rate structure at the NTS may be changed to a direct, DOE-funded, full cost recovery program similar to those at other national laboratories (e.g., Idaho National Engineering Laboratory). The impact this will have on NTS' unit disposal cost is not known at this time; it is assumed that the cost will increase. Therefore, the higher rates charged at Hanford could reflect the potential impact of cost increases at the NTS in the future.

As discussed in Chapter 5, the NTS is considered to be the most favorable existing DOE location for disposal of the DU currently in storage at the GDPs, primarily for three reasons: (1) lower disposal costs; (2) current WAC allow the disposal of DU as $\mathrm{U}_{3} \mathrm{O}_{8}$; and. (3) the climatological, geological, and hydrogeological environment is very suitable for preventing any migration of radionuclides to the ground water or the surface and atmosphere. The current rates $\left(\$ 10 / \mathrm{ft}^{3} \text { for } \mathrm{LLW} ; \$ 36 / \mathrm{ft}^{3} \text { for } \mathrm{MW}\right)^{\mathrm{p}}$ used in this study for the NTS are considerably lower than the corresponding rates charged at the Hanford Site $\left(\$ 58.70 / \mathrm{ft}^{3}\right.$ for LLW; $\$ 168.68 / \mathrm{ft}^{3}$ for MW). ${ }^{17, q}$ This is partially due to differences in volumes of waste handled. The NTS disposes of approximately 1 million $\mathrm{ft}^{3}$ of LLW per year compared with approximately $300,000 \mathrm{ft}^{3}$ at Hanford; therefore, economics of scale impact the unit cost charged to the generator.

Two cases were considered in assessing the costs of the $\mathrm{U}_{3} \mathrm{O}_{8}$ LLW disposal at NTS. First, direct burial in below-grade trenches and/or craters and, secondly, disposal of the $\mathrm{U}_{3} \mathrm{O}_{8}$ in an Above Grade Earth Mounded Concrete Vault (AGEMCV). ${ }^{19}$ The AGEMCV (see Figure 4) concept allows. for retrieval of the DU 70 to 100 years into the future if the DU can be

p. Max Dolenc, Reynolds Electric \& Engineering Co., Inc., Personal communication with Tim Hertzler, SAIC, May 6, 1993.

q. N. P. Willis, Westinghouse Hanford Company, Personal communication with Tim Hertzler, SAIC, May 20, 1993. 


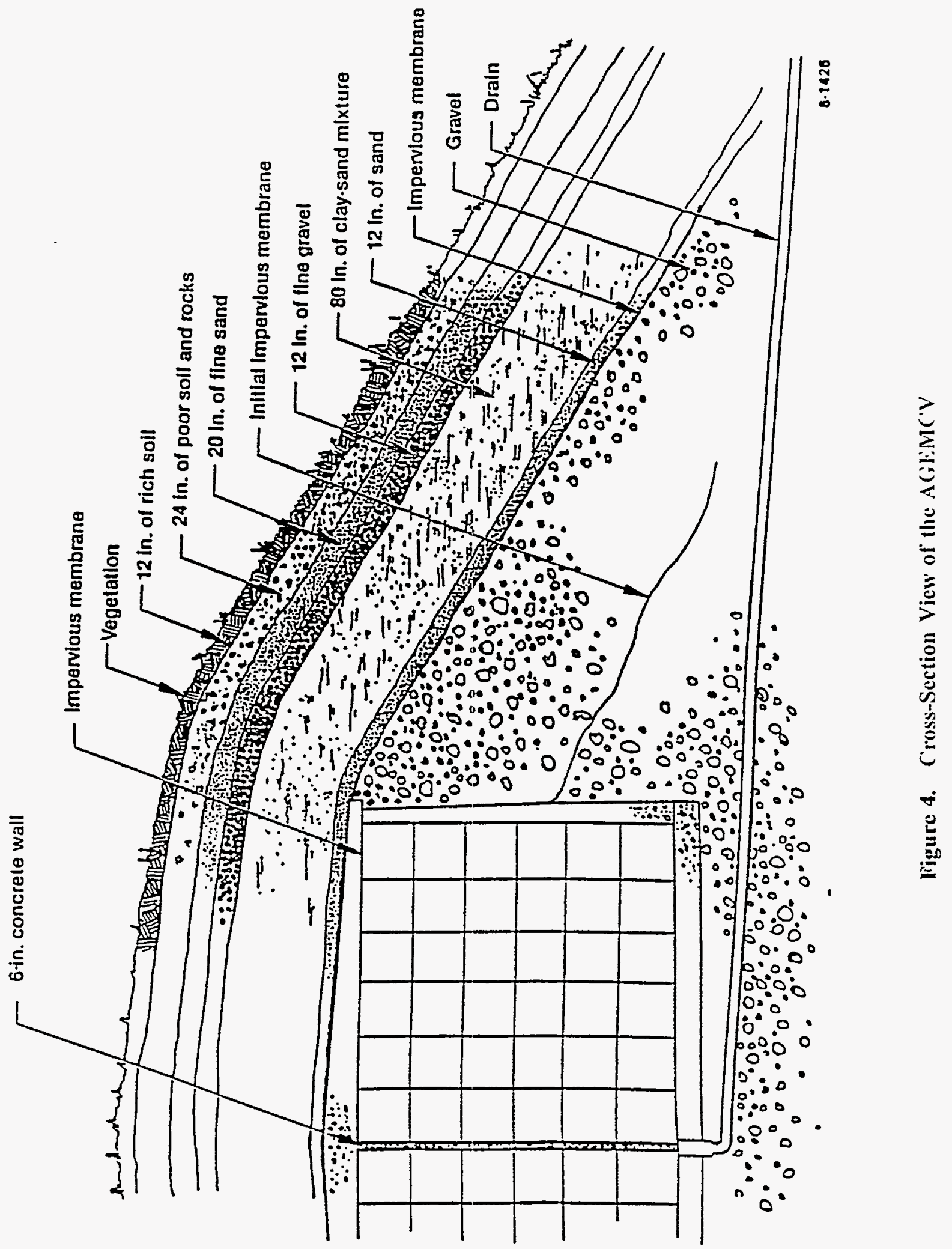


economically utilized in the breeder reactor program or for feed stock for further enrichment (e.g., AVLIS feed). In the context of this report, a "retrievable disposal" option is one in which the DU would be disposed in such a manner as to be relatively easy to retrieve in pure form if desired, yet at the same time potentially meet all long-term disposal criteria if retrieval in the future is not desired. It should be noted that the AGEMCV is only one of many potential options for retrievable disposal. Below grade vaults, burial in concrete overpacks, and. due to the arid conditions at NTS, drummed DU buried in below-grade trenches/craters may provide retrievable disposal. An extensive evaluation to determine the best retrievable disposal option was not performed for this report. If retrievability is determined to be a high priority consideration, then it is recommended that a thorough evaluation of the options be performed.

\subsection{Cost Estimate Objective and Approach}

The objective of this chapter is to develop a comprehensive baseline disposal cost estimate for comparison to other DU management options (e.g., DU metal as shielding). To accomplish this, all relevant disposal cost elements must be considered--applying the at-site burial charge per unit of mass or volume does not realistically represent the total disposal cost. The following costs elements are included in this report: (1) conversion to $\mathrm{U}_{3} \mathrm{O}_{8}$, (2) disposal container, (3) transportation, (4) environmental/safety documentation and permitting, and (5) direct burial of the $\mathrm{U}_{3} \mathrm{O}_{8}$ and the $\mathrm{CaF}_{2}$. In addition to these costs, engineering design, construction, and operations costs are applied to the AGEMCV case. Cost estimates for RCRA MW disposal are detailed separately from LLW disposal costs and also include a retrievable disposal case. The cost data are based on the available literature, current low-level and mixed waste disposal operations conducted at NTS and Hanford, telephone interviews, and vendor quotes.

The costs are presented for each cost element as total dollars and on a per unit basis of dollars per kilogram uranium. All costs are presented in 1993 dollars even though it is anticipated that the construction and operation of a conversion facility to convert the $\mathrm{UF}_{6}$ into $\mathrm{U}_{3} \mathrm{O}_{8}$ for disposal could not occur for at least 10 years.

The costs were developed using the following assumptions and data:

- The as-packaged density of $\mathrm{U}_{3} \mathrm{O}_{8}$ is $2.7 \mathrm{~g} / \mathrm{cm}^{3}\left(0.07646 \mathrm{MT} / \mathrm{ft}^{3}\right)$, which is $90 \%$ of the compacted material density.

- The mass fraction of uranium (U) to $\mathrm{U}_{3} \mathrm{O}_{8}$ is 0.848 .

- The mass fraction of $\mathrm{CaF}_{2}$ generated to $\mathrm{UF}_{6}$ input is 0.665 and the as-packaged density of $\mathrm{CaF}_{2}$ is $1.2 \mathrm{~g} / \mathrm{cm}^{3}\left(0.03398 \mathrm{MT} / \mathrm{ft}^{3}\right){ }^{2}$

- The $\mathrm{CaF}_{2}$ is disposed of as a low-level waste even though residual uranium contamination is very low, as discussed below.

The $\mathrm{U}_{3} \mathrm{O}_{8}$ and $\mathrm{CaF}_{2}$ are solidified to meet proposed Hanford LLW WAC. 
Solidification of both the $\mathrm{U}_{3} \mathrm{O}_{8}$ and the $\mathrm{CaF}_{2}$ is assumed to be necessary at either DOE site if ever $\mathrm{U}_{3} \mathrm{O}_{8}$ or $\mathrm{CaF}_{2}$ are defined as $\mathrm{MW}$.

Solidification of the $\mathrm{U}_{3} \mathrm{O}_{8}$ and the $\mathrm{CaF}_{2}$ with any binding agent (e.g., Portland cement. polyethylene) results in an increase in waste volume by a factor of two.

A $50 \%$ waste loading by weight is assumed for the solidification process.

Retrievable disposal will only be evaluated for unsolidified $\mathrm{U}_{3} \mathrm{O}_{8}$.

Based on the data and assumptions noted here and earlier, the quantities of waste requiring disposal are 5,570,000 $\mathrm{ft}^{3}(426,000 \mathrm{MT})$ of $\mathrm{U}_{3} \mathrm{O}_{8}$ and $10,450,000 \mathrm{ft}^{3}(355,000 \mathrm{MT})$ of $\mathrm{CaF}_{2}$. Solidification of these waste streams to meet site-specific WAC requirements at Hanford or for RCRA treatment will essentially double the volume of waste, approximately doubling the cost of disposing of the DU. Some reduction of the disposal costs can possibly occur, as outlined in the following discussion.

The $\mathrm{CaF}_{2}$ produced from neutralization of the $\mathrm{HF}$ will have very low residual uranium concentration--the HF from the French defluorination conversion process contains approximately $1 \mathrm{ppm}$ uranium and has been noted in one reference to contain as low as $32 \mathrm{ppb}^{2}$ Upon neutralization, this residual uranium contamination is diluted significantly by the addition of slake lime $(\mathrm{CaO})$. Although there are no Below Regulatory Concern (BRC) limits establishing when a waste can be disposed in a sanitary landfill, the EPA, NRC, and DOE continue to pursue such standards, and these may allow this very low activity waste to be disposed of in such a manner. Additionally, the cost of $\mathrm{CaF}_{2}$ disposal may be avoided entirely if effective decontamination and recycling of the HF is possible on a large-scale basis and free release limits are established in the future. Secondly, the $\mathrm{CaF}_{2}$ may only require Strong-Tight container packaging rather than Type A packaging per DOT regulation due to its very low activity. Strong-Tight containers, whether drums or metal boxes, do not have to pass the same strict quality assurance requirements that Type A packages do. Therefore, less costly DOT 17E drums $(\$ 26.55)^{\mathrm{r}}$ may replace the DOT $17 \mathrm{C}$ drums $(\$ 50.00)^{19}$ used in this study for the $\mathrm{CaF}_{2}$ waste.

The cost of converting the $\mathrm{UF}_{6}$ to $\mathrm{U}_{3} \mathrm{O}_{8}$ provided in this report was obtained directly from a previous study performed by Martin Marietta Energy Systems, Inc., (MMES) in 1991. ${ }^{2}$ Costs associated with continued $\mathrm{UF}_{6}$ cylinder maintenance and $\mathrm{U}_{3} \mathrm{O}_{8} / \mathrm{CaF}_{2}$ disposal were not used because the scope of work for this report required that costs be estimated as if the processing could occur immediately, thus continued maintenance of $\mathrm{UF}_{6}$ cylinders is not applicable. The cost for disposal of the $\mathrm{U}_{3} \mathrm{O}_{8}$ and $\mathrm{CaF}_{2}$ was based on current information supplied by the disposal facilities (i.e., NTS, Hanford), commercial shippers, and container manufacturers. Decontamination and decommissioning costs were not included because they are not part of the cost bases for other alternatives, and the purpose of this report is to provide costs for comparison with those of other options. [For example, the $U$ metal disposal option

r. Idaho National Engineering Laboratory Stores Warehouse, Personal Communication with Tim Hertzler, SAIC, March, 1993. 
(Appendix A) and DU recycle alternatives do not include $D \& D$ costs for the $U_{6}$ to $U$ metal conversion facility.]

\subsection{Conversion Costs}

The MMES study established the costs (in 1992 dollars) for two scenarios:

1. Base Case with $\mathrm{HF}$ re-sale

2. Base Case with $\mathrm{HF}$ neutralization/ $\mathrm{CaF}_{2}$ disposal.

The cost data for the second case were reviewed and the costs directly applicable to the conversion process were extracted and used in this report; these cost data are listed below. The costs include the base case value plus the expected increase for HF neutralization without contingency. The MMES work breakdown structure (WBS) number is included for reference purposes.

Conversion Costs Elements:

1. Interim storage facility construction (WBS 1.5.1.2) $\$ 10 \mathrm{M}$

2. Feed and cylinder handling facility (WBS 1.5.1.3.1) $\$ 17 \mathrm{M}$

3. Conversion and waste handling facilities (WBS 1.5.1.3.2) $\$ 103 \mathrm{M}$ [includes $\$ 76 \mathrm{M}$ base case $+\$ 27 \mathrm{M}$ for HF neutralization]

4. Support facilities (WBS 1.5.1.3.3) \$11 M

5. Construction manager fee (WBS 1.5.1.3.4.1) $\$ 21 \mathrm{M}$ [includes $\$ 17 \mathrm{M}$ base case $+\$ 4 \mathrm{M}$ for $\mathrm{HF}$ neutralization]

6. Construction support (WBS 1.5.1.3.4.2)

$\$ 13 \mathrm{M}$ [includes $\$ 10 \mathrm{M}$ base case $+\$ 3 \mathrm{M}$ for HF neutralization]

7. Program planning (WBS 1.5.1.3.4.3)

[includes $\$ 12 \mathrm{M}$ base case $+\$ 2 \mathrm{M}$ for HF neutralization]

$\$ 14 \mathrm{M}$

8. Design and Title III (WBS 1.5.1.3.4.4)

$\$ 17 \mathrm{M}$

[this includes $\$ 15 \mathrm{M}$ base case $+\$ 2 \mathrm{M}$ for HF neutralization]

9. Conversion operations (WBS 1.5.1.3.5)

$\$ 89 \mathrm{M}$ [this includes $\$ 36 \mathrm{M}$ base case $+\$ 53 \mathrm{M}$ for HF neutralization]

$\$ 295 \mathrm{M}$

The conversion and ancillary facilities were sized to handle a base case throughput of $35,000 \mathrm{MTU}$ in five years. Dividing the total estimated cost of $\$ 295 \mathrm{M}$ by the process throughput rate results in a unit conversion cost of $\$ 8.40 / \mathrm{kgU}$. Assuming that this unit cost 
applies to conversion of the entire inventory of $\mathrm{UF}_{6}$, without regard to cost reduction due to economies of scale. the cost of converting the $361,000 \mathrm{MTU}$ stored at the GDPs would be approximately $\$ 3.0$ billion

\subsection{LLW Shallow-Land Burial Costs}

The NTS LLW disposal costs are currently established at $\$ 10$ per cubic foot of waste; the Hanford Site charges $\$ 58.70$ per cubic foot. These costs include the excavation of disposal trenches, handling and placement of as-received waste containers that meet the respective WACs, and operational and post-operational monitoring costs. For the $\mathrm{U}_{3} \mathrm{O}_{8}$ and $\mathrm{CaF}_{2}$, the disposal container is considered to be a DOT approved $17 \mathrm{C}$ open head steel drum. DOT 17C drums are qualified as Type A containers. Transport of drummed material via both truck and railroad was assessed. Under the Hanford disposal case, it was assumed that the material would be solidified at the point of conversion, thus incurring additional transportation costs. The environmental compliance and safety costs [e.g., EIS, PSD/PTC, Safety Analysis Report (SAR)] were estimated and assumed to be the same for shallow land burial at either disposal site.

\subsubsection{Disposal Container Cost}

Disposal container costs are significant, especially if a retrievable disposal option such as an AGEMCV is used. The cost of construction of an AGEMCV depends on the volume of disposal space required to contain the total inventory of DU. Efficient packaging and stacking (i.e., minimization of void volume) are not only significant for savings in capital costs of construction, but are key factors in the longevity and radiological performance assessment of the disposal unit.

\subsubsection{NTS Disposal}

It is assumed that the compacted $\mathrm{U}_{3} \mathrm{O}_{8}$ from the conversion facility. will meet NTS WAC requirements for fines as discussed in Section 5.1.1.2. Therefore, no overpack drums (e.g., 83 or 85 gallon drums) are assumed to be necessary nor is solidification of the $\mathrm{U}_{3} \mathrm{O}_{3}$ prior to burial assumed to be necessary. The cost of 208-liter (55-gallon) $17 \mathrm{C}$ drums is $\$ 50$ per drum, ${ }^{r}$ and the number of drums required to dispose of the inventory of $\mathrm{U}_{3} \mathrm{O}_{8}$ is $\sim 818,000$. The number of drums required for disposal of the inventory of $\mathrm{CaF}_{2}$ is estimated to be $\sim 1,412,000$ based on the low packaging density of the material $\left(1.2 \mathrm{~g} / \mathrm{cm}^{3}\right)$. The total costs for the $\mathrm{U}_{3} \mathrm{O}_{8}$ and $\mathrm{CaF}_{2}$ disposal containers are $\$ 40.9$ and $\$ 70.6$ million, respectively. This is a disposal container cost of approximately $\$ 0.11 / \mathrm{kgU}$ for the $\mathrm{U}_{3} \mathrm{O}_{8}$ and $\$ 0.20 / \mathrm{kgU}$ for the $\mathrm{CaF}_{2}$. Table 10 provides cost breakdowns for each disposal cost element for the NTS as well as the Hanford Site.

\subsubsection{Hanford Disposal}

For the disposal of $\mathrm{U}_{3} \mathrm{O}_{3}$, which is a Category 3 waste per Hanford Site classification limits provided in Table 9, solidification will be necessary. This will result in an approximate doubling of the disposal volume and associated disposal costs over that of the NTS option. As discussed in Section 6.1 above, the low levels of uranium in the $\mathrm{CaF}_{2}$ should qualify this waste stream as a Category 1 waste per the Hanford WAC and the requirement of solidification may 
Table 10. Shallow-Land Burial Cost Estimates"

\begin{tabular}{|c|c|c|c|c|c|c|c|}
\hline \multirow[b]{2}{*}{ Site } & \multirow[b]{2}{*}{ Waste Stream } & \multicolumn{6}{|c|}{ Cost Elements } \\
\hline & & Conversion & Containers & Transportation & Burial & $\begin{array}{c}\text { Environmental } \\
\text { Compliance }\end{array}$ & Totals \\
\hline \multirow[t]{3}{*}{ NTS } & $\mathrm{U}_{3} \mathrm{O}_{8}$ & $\begin{array}{c}\$ 3.0 \mathrm{~B} \\
\$ 8.40 / \mathrm{kgU}\end{array}$ & $\begin{array}{c}\$ 40.9 \mathrm{M} \\
\$ 0.11 / \mathrm{kgU}\end{array}$ & $\begin{array}{c}\$ 65.2 \mathrm{M}^{\mathrm{c}} \\
\$ 0.18 / \mathrm{kgU}\end{array}$ & $\begin{array}{c}\$ 55.7 \mathrm{M} \\
\$ 0.15 / \mathrm{kgU}\end{array}$ & $\begin{array}{c}\$ 9.0 \mathrm{M} \\
\$ 0.02 / \mathrm{kgU}\end{array}$ & $\begin{array}{c}\$ 3.2 \mathrm{~B} \\
\$ 8.86 / \mathrm{kgU}\end{array}$ \\
\hline & $\mathrm{CaF}_{2}$ & $--^{b}---$ & $\begin{array}{c}\$ 70.6 \mathrm{M} \\
\$ 0.20 / \mathrm{kgU}\end{array}$ & $\begin{array}{c}\$ 56.6 \mathrm{M} \\
\$ 0.16 / \mathrm{kgU}\end{array}$ & $\begin{array}{l}\$ 104.5 \mathrm{M} \\
\$ 0.29 / \mathrm{kgU}\end{array}$ & $-\ldots$ & $\begin{array}{l}\$ 231.7 \mathrm{M} \\
\$ 0.65 / \mathrm{kgU}\end{array}$ \\
\hline & Subtotals & $\begin{array}{c}\$ 3.0 \mathrm{~B} \\
\$ 8.40 / \mathrm{kgU} \\
\end{array}$ & $\begin{array}{l}\$ 111.5 \mathrm{M} \\
\$ 0.31 / \mathrm{kgU} \\
\end{array}$ & $\begin{array}{l}\$ 121.8 \mathrm{M} \\
\$ 0.34 / \mathrm{kgU} \\
\end{array}$ & $\begin{array}{l}\$ 160.2 \mathrm{M} \\
\$ 0.44 / \mathrm{kgU}\end{array}$ & $\begin{array}{c}\$ 9.0 \mathrm{M} \\
\$ 0.02 / \mathrm{kgU}\end{array}$ & $\begin{array}{c}\$ 3.4 \mathrm{~B} \\
\$ 9.51 / \mathrm{kgU}\end{array}$ \\
\hline \multirow[t]{3}{*}{ Hanford } & $\mathrm{U}_{3} \mathrm{O}_{8}$ & $\begin{array}{c}\$ 3.0 \mathrm{~B} \\
\$ 8.40 / \mathrm{kgU}\end{array}$ & $\begin{array}{c}\$ 81.8 \mathrm{M}^{\mathrm{c}} \\
\$ 0.23 / \mathrm{kgU}\end{array}$ & $\begin{array}{l}\$ 135.5 \mathrm{M}^{\mathrm{c}, \mathrm{f}} \\
\$ 0.38 / \mathrm{kgU}\end{array}$ & $\begin{array}{l}\$ 654.0 \mathrm{M}^{\circ} \\
\$ 1.81 / \mathrm{kgU}\end{array}$ & $\begin{array}{c}\$ 9.0 \mathrm{M}^{\mathrm{g}} \\
\$ 0.02 / \mathrm{kgU}\end{array}$ & $\begin{array}{c}\$ 3.9 \mathrm{~B} \\
\$ 10.84 / \mathrm{kgU}\end{array}$ \\
\hline & $\mathrm{CaF}_{2}$ & ---'--- & $\begin{array}{l}\$ 141.0 \mathrm{M}^{\mathrm{e}} \\
\$ 0.39 / \mathrm{kgU}\end{array}$ & $\begin{array}{l}\$ 117.0 \mathrm{M}^{\mathrm{e}, \mathrm{f}} \\
\$ 0.32 / \mathrm{kgU}\end{array}$ & $\begin{array}{l}\$ 1,227 \mathrm{M}^{\mathrm{e}} \\
\$ 3.40 / \mathrm{kgU}\end{array}$ & $-.-d^{d}-.$. & $\begin{array}{c}\$ 1.5 \mathrm{~B} \\
\$ 4.15 / \mathrm{kgU}\end{array}$ \\
\hline & Subtotals & $\begin{array}{c}\$ 3.0 \mathrm{~B} \\
\$ 8.40 / \mathrm{kgU}\end{array}$ & $\begin{array}{l}\$ 222.8 \mathrm{M} \\
\$ 0.62 / \mathrm{kgU}\end{array}$ & $\begin{array}{l}\$ 252.5 \mathrm{M} \\
\$ 0.70 / \mathrm{kgU}\end{array}$ & $\begin{array}{c}\$ 1,881.0 \mathrm{M} \\
\$ 5.21 / \mathrm{kgU}\end{array}$ & $\begin{array}{c}\$ 9.0 \mathrm{M} \\
\$ 0.02 / \mathrm{kgU}\end{array}$ & $\begin{array}{c}\$ 5.4 \mathrm{~B} \\
\$ 15 / \mathrm{kgU}\end{array}$ \\
\hline \multicolumn{8}{|c|}{$\begin{array}{l}\left.\text { a. Disposal as LLW per site specific WAC and burial rates [ } \mathrm{NTS}=\$ 10 / \mathrm{ft}^{3} ; \mathrm{Hanford}=\$ 58.70 / \mathrm{ft}^{3}\right] \text {. } \\
\text { b. Conversion cost applied to } \mathrm{U}_{3} \mathrm{O}_{8} \text { only - not specific to individual waste streams. } \\
\text { c. Truck transportation to NTS only. } \\
\text { d. Environmental compliance costs are assumed to cover both the } \mathrm{U}_{3} \mathrm{O}_{8} \text { and } \mathrm{CaF}_{2} \text { disposal. } \\
\text { e. Cost increase is due to increased disposal volume resulting from solidification. } \\
\text { f. Truck transport costs; rail transport costs are } \$ 127 \mathrm{M}(\$ .35 / \mathrm{kgU}) \text { and } \$ 111 \mathrm{M}(\$ .31 / \mathrm{kgU}) \text { for } \mathrm{U}_{3} \mathrm{O}_{8} \text { and } \mathrm{CaF}_{2} \text {, respectively. } \\
\text { g. Environmental compliance cost at each site assumed to be the same. }\end{array}$} \\
\hline
\end{tabular}


not apply. However, for a bounding case, solidification is assumed to be necessary for the $\mathrm{CaF}_{2}$ as well as the $\mathrm{U}_{3} \mathrm{O}_{8}$. Therefore, the total volume of $\mathrm{U}_{3} \mathrm{O}_{8}$ to be disposed of will increase to $11,140,000$ cubic feet, and the $\mathrm{CaF}_{2}$ volume would increase to $20,900,000$ cubic feet. Based on these volumes, the total container costs are $\$ 81.8$ million $(\$ 0.23 / \mathrm{kgU})$ for the $\mathrm{U}_{3} \mathrm{O}_{8}$ and $\$ 141.0$ million $(\$ 0.39 / \mathrm{kgU})$ for the $\mathrm{CaF}_{2}$.

\subsubsection{Transportation Cost}

Railroad transport of DU to the NTS is not a viable alternative since no railroad spur extending from a main line track to NTS exists. Therefore, only transportation by truck was estimated for disposal at NTS. Both rail and truck transportation are viable alternatives for shipping the $\mathrm{DU}$ and $\mathrm{CaF}_{2}$ to the Hanford site. Cost estimates for the transport of radioactive materials were obtained from Ebasco Inc. ${ }^{s}$ and Ranger Transportation, ' a certified hazardous materials transportation company. Railroad transport cost to Hanford, WA were based on 1991 figures developed by Ebasco Services ${ }^{s}$ and reported by Norfolk Southern Railroad. The 1991 prices were adjusted to 1993 dollars using a $4 \%$ inflation rate. The number of truck or rail car loads required to transport all the wastes to the disposal sites was estimated based on a truck or rail car rated weight capacity and a total acceptable drum weight at NTS of 1,200 pounds. ${ }^{12}$

\subsubsection{NTS Disposal}

Trucking costs to NTS were reported to be $\$ 2,800, \$ 2,700$, and $\$ 2,350$ per truck load from Piketon, Oak Ridge, and Paducah, respectively. ${ }^{t}$ To estimate the cost for transporting the uranium oxide $\left(\mathrm{U}_{3} \mathrm{O}_{8}\right)$ and $\mathrm{CaF}_{2}$ waste to NTS, the total number of truck loads required was calculated based on a weight limit of $42,000 \mathrm{lbs}$ per truck. The resulting capacity, per truck, of $\mathrm{U}_{3} \mathrm{O}_{8}$, packaged in $17 \mathrm{C}$ drums, is $15.5 \mathrm{MTU}$. Thus, the total number of truck loads required to transport the $361.000 \mathrm{MTU}$ is $\sim 23,300$. As a bounding case, the trucking cost from Piketon, $\mathrm{OH}$, to NTS (i.e., $\$ 2,800$ per trip) was used for all shipments. The transportation cost was estimated to be $\$ 0.18 / \mathrm{kgU}$ or $\$ 65.2$ million total for the $\mathrm{U}_{3} \mathrm{O}_{8}$. For the $\mathrm{CaF}_{2}$, the mass per truckload is 17.6 tonnes, therefore, $\sim 20,200$ truckloads would be required. At $\$ 2,800 /$ truckload, the cost of shipping the $\mathrm{CaF}_{2}$ to NTS will be $\$ 56.6$ million or approximately $\$ 0.16 / \mathrm{kgU}$.

\subsubsection{Hanford Disposal}

Costs for truck transport of the material from Piketon, Ohio to the Hanford Site were quoted at $\$ 2,900$ per truck load, ${ }^{t}$ while rail shipments were estimated to be $\$ 12,980$ per 100 -ton flatcar. ${ }^{\mathrm{s}}$ Since the proposed Hanford waste acceptance limits require the $\mathrm{U}_{3} \mathrm{O}_{8}$ to be solidified prior to disposal, it was assumed that the solidification would occur at the point of conversion. Also it

s. Gary Kenison, Ebasco Inc., Personal Communication with Tim Hertzler, SAIC, March, 1993.

t. Jeff Baker, Ranger Transportation, Personal Communication with Tim Hertzler, SAIC, April 5, 1993. 
was assumed, as a worst case, that it would be necessary to solidify the $\mathrm{CaF}_{2}$ prior to transport. Therefore, the total volume of waste transported was increased by a factor of two.

The total trucking cost to Hanford, taking into account the volume increase of solidification and the truck capacity, is $\$ 135.5$ million for the $\mathrm{U}_{3} \mathrm{O}_{8}$ and $\$ 117.0$ million for the $\mathrm{CaF}_{2}$. The cost per kilogram of uranium is $\$ 0.38$ and $\$ 0.32$ for the $U_{3} \mathrm{O}_{8}$ and $\mathrm{CaF}_{2}$, respectively.

For rail transport, a 100-ton flat car is capable of carrying approximately 37 MTU of solidified $\mathrm{U}_{3} \mathrm{O}_{8}$. To transport the $361,000 \mathrm{MTU}$ of DU would require $\sim 9,800$ flat cars. Thus, the total cost for railroad transport of the $\mathrm{U}_{3} \mathrm{O}_{8}$ was calculated to be $\$ 127$ million $(\$ 0.35 / \mathrm{kgU})$. The flat car capacity of $\mathrm{CaF}_{2}$ is approximately 41.0 tonnes, which translates into $\sim 8,600$ rail cars being needed to transport the total inventory of $\mathrm{CaF}_{2}$. A cost of $\$ 111$ million $(\$ 0.31 / \mathrm{kgU})$ was calculated for rail shipment of the $\mathrm{CaF}_{2}$ to Hanford.

\subsubsection{Burial Cost}

\subsubsection{NTS Disposal}

The NTS has established different rates for DOE versus non-DOE generators sending low-level waste for disposal. The rate of $\$ 10 / \mathrm{ft}^{3}$ is charged to DOE generators and is not a full cost recovery rate. For full cost recovery, an increase of approximately $19 \%$ is added to the DOE rate and charged to the non-DOE generators (i.e., $\$ 11.90 / \mathrm{ft}^{3}$ ). ${ }^{\mathrm{p}}$ As discussed in Chapters 5.0 and 6.0, the NTS is negotiating with the DOE and the Inspector General (IG) to restructure the rate charges for management and operation of the NTS disposal sites. The impact of rate restructuring is not known at this time, therefore the current DOE rate of $\$ 10 / \mathrm{ft}^{3}$ is used here.

At $\$ 10$ per cubic foot, the disposal of $5,570,000$ cubic feet of $U_{3} \mathrm{O}_{8}$ will cost $\$ 55.7$ million. The unit cost for burial is therefore $\$ 0.15 / \mathrm{kgU}$, excluding any costs of transportation, packaging and handling, or conversion prior to reaching the disposal site. This cost does not include a potential increase in cost of burial if the DU is required to be buried at a greater depth than current LLW shallow-land burial practices at NTS. As noted in section 5.1.1.2, the NTS performance assessment criteria may require the DU to be buried at a greater depth to meet NESHAP radon emission limits of $20 \mathrm{pCi} / \mathrm{m}^{2}$-s. If increased burial depth is necessary based on radiological modeling, the depth of cover will increase from $1 \mathrm{~m}$ to approximately $15 \mathrm{~m}$. The cost impact, if any, related to this increased depth of burial is not known at this time.

For the $\mathrm{CaF}_{2}\left(10,450,000 \mathrm{ft}^{3}\right)$, the cost of handling and burial at NTS will be approximately $\$ 104.5$ million or $\$ 0.29 / \mathrm{kgU}$.

\subsubsection{Hanford Disposal}

With the Hanford disposal rate currently at $\$ 58.70$ per cubic foot, the cost of disposing the DU, after solidification, would be $\$ 654.0$ million or $\$ 1.81 / \mathrm{kgU}$. This is a 12 -fold increase over that of NTS disposal. If the $\mathrm{CaF}_{2}$ is also disposed at Hanford and the same restrictions apply (i.e., solidification to meet fines requirements), it will cost approximately $\$ 1.23$ billion or $\$ 3.40 / \mathrm{kgU}$. This brings the total cost for disposing of the DU and the main byproduct stream 
$\left(\mathrm{CaF}_{2}\right)$ to $\$ 5.21 / \mathrm{kgU}$ for burial charges alone, excluding the cost of containers, transportation, etc. It is apparent that it is important to characterize, treat, and/or compact the $\mathrm{CaF}_{2}$ to decrease the volume needing disposal, or to recycle the HF to decrease the economic impact to the overall DU disposal option.

\subsubsection{Environmental Compliance Costs}

Numerous Federal environmental statutes regulate the disposal of LLW. The primary statutes that would apply to DU, if in the future the DU is considered a waste destined for disposal, are the following: (1) AEA, (2) NEPA, (3) CAA, (4) CWA, (5) Safe Drinking Water Act (SDWA), and (6) Hazardous Materials Transportation Act. The DOE, NRC, and other government agencies are required to regulate the disposal of radioactive waste in such a way as to ensure compliance with the various controlling statutes. Specific DOE and NRC orders and policies were presented and discussed in Chapter 4.

The costs associated with environmental compliance begin during the conceptual design phase of a disposal facility with the initiation of the site selection, pre-operational monitoring, and NEPA review processes. DOE Order 5400.1, General Environmental Protection Program, specifies that pre-operational monitoring activities should begin not less than one year, and preferably two years, prior to construction and start-up. The baseline data generated during pre-operational monitoring will be used in developing NEPA review documents. NEPA documents required for DU disposal considered for this report are all supporting documents (e.g. environmental checklist, action description memorandum, etc.) leading up to and including an EIS. In addition, costs associated with air permit requirements under the CAA and environmental safety and health (ES\&H) requirements are included as environmental compliance costs. The three primary cost elements associated with the CAA and ES\&H are the PSD and PTC review and permit processes under the CAA and the SAR identified in DOE 5481.1B.

Currently, EG\&G Idaho, Inc. is in the conceptual design phase of developing a LLW/MW disposal facility at the Idaho National Engineering Laboratory (INEL). The envisioned disposal facility would be a RCRA-approved facility capable of receiving and disposing of both LLW and MW in separate disposal cells. EG\&G's estimated cost for the environmental compliance requirements for a LLW/MW facility is approximately $\$ 11$ million. " The environmental compliance costs for DU disposal were scaled down from the INEL estimates since MW cost elements would not be included. The resulting environmental and safety compliance costs are assumed to be $\$ 9$ million, or $\$ 0.02 / \mathrm{kgU}$ for DU disposal.

\subsection{Retrievable Disposal}

Since DU may have value in the future as either feedstock for the AVLIS enrichment process or core and blanket material for the liquid metal fast breeder reactor technology. the potential for disposal in such a way as to permit retrievability was evaluated. Several alternative disposal concepts for LLW were reviewed in developing a possible retrievable disposal option.

u. Mary Jorgenson Waters, EG\&G Inc., Personal Communication with Tim Hertzler, SAIC, March. 1993. 
Studies performed in 1986 through 1989 by the National Low-Level and Defense Low-Level Waste programs provided information on waste disposal alternatives ranging from below grade burial to above grade vaults and variations in between. The AGEMCV, which incorporates favorable characteristics of both above and below grade disposal vault options, was used for establishing a preliminary cost estimate for the retrievable disposal strategy.

The AGEMCV concept for LLW disposal consists of individual disposal vaults, constructed using high-grade Type $\mathrm{V}$ portland cement, situated above grade and above the probable maximum flood plain. Using a bridge crane and specially designed handling hardware (because no external lifting hardware projects from the LLW box), a treated and grouted waste is placed in a tight monolithic stack without any void volume. As the vault is filled, an impervious membrane is placed on the waste stack and a concrete roof slab is poured on top. The solidified LLW supports the roof slab, while an overlying earthen cap prevents the future subsidence and resulting water infiltration typically associated with non-treated waste burial. The final closure of the vault is to cover it with an impervious membrane and a multi-layered earthen cover specifically designed to prevent water infiltration, erosion, or inadvertent intruder penetration.

A radiological performance assessment was performed by Rogers and Associates Engineering Corporation ${ }^{20}$ in 1989 on the LLW AGEMCV being evaluated at the INEL. The assessment concluded that the concrete vault would last 5000 years and the solidified waste form would not begin to deteriorate until then. The solidified inorganic waste form and the design of the vault with essentially no void volume were the most significant factors in the performance assessment results. Two significant differences will exist between the design, construction, and radiological performance of an AGEMCV for LLW versus DU disposal: (1) the DU would not be in a solidified form and (2) the void volume resulting from disposal of DU in drums would allow subsidence and water infiltration and leaching beyond that analyzed for LLW. Without solidification of the DU or $100 \%$ stacking efficiency, the performance of the disposal unit would be significantly different than that of the LLW AGEMCV analyzed by Rogers and Associates. Therefore, if the retrievable disposal vault approach is considered, additional investigation and assessments would be required.

The cost estimates for the engineering design, construction, and operation of the AGEMCV concept were developed using data from Application of Existing Low-Level Waste Technology Offers 17-to-1 Volume Reduction and Enhanced Disposal at Low Cost, ${ }^{19}$ modified to best fit the scenario for the DU disposal.

\subsubsection{Environmental Compliance Costs}

The environmental compliance costs for the retrievable disposal case are considered here to be the same as those developed for the shallow-land disposal option detailed in Section 6.3.4, namely $\$ 9$ million or $\$ 0.02 / \mathrm{kgU}$.

\subsubsection{Design and Construction Costs}

The cost for the engineering design and construction of the AGEMCVs for DU disposal developed in this report is based on the conceptual design of the LLW disposal facility evaluated at the INEL. The conceptual cost estimate developed by EG\&G included engineering design and 
inspection through Title II design, direct and indirect construction costs, construction management and project administration, and a $25 \%$ contingency. These cost data were considered representative for preliminary cost estimates applicable to retrievable disposal of the DU at the NTS.

Considering the void volume $(-35 \%)$ in a vault resulting from the use of 208-liter drums as the disposal containers and the total volume of $\mathrm{DU}$ as $\mathrm{U}_{3} \mathrm{O}_{8}$, construction of 35 AGEMCVs $\left(\sim 268,000 \mathrm{ft}^{3} /\right.$ vault), as a minimum, would be required. In 1988 , the cost to design and construct three vaults was calculated to be $\$ 9$ million. Modifying this cost to 1993 dollars at an inflation rate of $4 \%$ and increasing the cost for quality assurance (QA), assumed to be a factor of two, for construction of concrete structures meeting applicable nuclear safety requirements yields a cost of approximately $\$ 7.3$ million per vault. Therefore, the total present cost to design and construct 35 vaults for disposing of the 5,570,000 cubic feet of oxide at the NTS is estimated to be $\$ 255.5$ million $(\$ 0.71 / \mathrm{kgU})$.

\subsubsection{Operational Costs}

Operational costs for the retrievable disposal of DU are assumed to be the same as those associated with the current LLW activities conducted at NTS (i.e., $\$ 10 / \mathrm{ft}^{3}$ ). The burial of LLW involves the same receiving, handling, monitoring, and backfilling activities as would be required for retrievable disposal. Therefore, as a preliminary estimate, the operational cost for NTS disposal in an AGEMCV is $\$ 55.7$ million or $\$ 0.15 / \mathrm{kgU}$.

Costs for conversion of the $\mathrm{UF}_{6}$ to $\mathrm{U}_{3} \mathrm{O}_{8}$, disposal containers, transportation, and burial of $\mathrm{CaF}_{2}$ are the same as those reported in Section 6.3 for the shallow-land burial alternative at NTS. Total cost estimates for retrievable disposal are given in Table 11.

Table 11. Retrievable Disposal Cost Estimates

Cost Element

Conversion to $\mathrm{U}_{3} \mathrm{O}_{8}$

Disposal Containers

Transportation

Operation \& Maintenance

Environmental Compliance

Design \& Construction

Total

\section{NTS}

$\$ 3.0 \mathrm{~B}$

$111.5 \mathrm{M}$

$121.8 \mathrm{M}$

$160.2 \mathrm{M}$

$9.0 \mathrm{M}$

$255.5 \mathrm{M}$

$\$ 3.7 \mathrm{~B}(10.25 / \mathrm{kgU})$ 


\subsection{RCRA Disposal Costs}

Although DU is not now, and may never be, considered a RCRA waste, a disposal cost estimate is provided as a worst-case cost scenario. In no way should the establishment of a RCRA disposal cost estimate in this study be construed as an acknowledgement by the DOE that the DU is or will ever be defined as a RCRA waste. As discussed in Chapter 4.0. DU is defined as a source material under the AEA and is exempt from RCRA regulations. Even if the $\mathrm{UF}_{6}$ were declared a hazardous waste due to reactivity, the conversion products $\left(\mathrm{U}_{3} \mathrm{O}_{8}\right.$ and $\left.\mathrm{CaF}_{2}\right)$ would no longer exhibit this characteristic and would not, therefore, be considered a hazardous waste.

RCRA disposal estimates provided here are based on the disposal charges quoted by waste management personnel at NTS and Hanford. At the present time, both DOE sites are pursuing the establishment of RCRA-certified sub-surface disposal units. A RCRA-certified disposal unit is required to have an impermeable liner and leachate collection system. Currently, Hanford is the only site of the two that has received approval to construct a RCRA disposal unit: ${ }^{v}$ NTS is in the process of gaining approval from the State of Nevada.

The costs quoted for mixed waste handling and disposal at the NTS and Hanford are $\$ 36 / \mathrm{ft}^{3} \mathrm{p}$ and $\$ 168.68 / \mathrm{ft}^{3} \mathrm{q}$, respectively. The costs are reported to cover handling, disposal, preand post-operational monitoring, and interim storage and closure costs associated with mixed waste disposal. Conversion costs have been increased by $\$ 2.0$ billion to account for added expenses associated with the construction and operation of a generic RCRA treatment process since there is no defined hazard associated with the $\mathrm{U}_{3} \mathrm{O}_{8}$ or $\mathrm{CaF}_{2}$.

\subsubsection{NTS Disposal}

For the disposal of both the $\mathrm{U}_{3} \mathrm{O}_{8}$ and the $\mathrm{CaF}_{2}$ at NTS, the cost would be approximately $\$ 1.7$ billion or $\$ 4.71 / \mathrm{kgU}$, excluding the cost to convert and treat. Inclusion of the conversion and generic treatment costs increases the total dollars to $\$ 6.7$ billion or $\$ 18.56 / \mathrm{kgU}$. This rough-order-of-magnitude (ROM) cost compares with the $\$ 3.4$ billion ( $\$ 9.50 / \mathrm{kgU}$ ) for LLW disposal in Table 10. RCRA disposal costs along with LLW disposal costs are summarized in Table 12.

\subsubsection{Hanford Disposal}

The ROM cost for disposing of the $\mathrm{U}_{3} \mathrm{O}_{8}$ and $\mathrm{CaF}_{2}$ at Hanford is $\$ 10.9$ billion or $\$ 30.19 / \mathrm{kgU}$ inclusive of conversion, treatment, transport, burial, environmental compliance, and disposal containers. Essentially, there is no significant difference between truck or rail transport cost at the ROM level of accuracy detailed here.

v. Eric Erpenbeck, Westinghouse Hanford, Personal Communication with Tim Hertzler, SAIC, May, 1993. 
Table 12. Disposal Costs Summary - 1993 Dollars $^{2}$

\begin{tabular}{|c|c|c|}
\hline Type of Disposal & NTS & Hanford \\
\hline $\begin{array}{l}\text { LLW Shallow-Land Burial: } \\
\text { Conversion to } \mathrm{U}_{3} \mathrm{O}_{3} \\
\text { Disposal Costs } \\
\text { Total Costs }\end{array}$ & $\begin{array}{l}\$ 3.0 \mathrm{~B} \\
\frac{\$ 403 \mathrm{M}}{\$ 3.4 \mathrm{~B}}(\$ 9.50 / \mathrm{kgU})\end{array}$ & $\begin{array}{l}\$ 3.0 \mathrm{~B} \\
\$ 2.4 \mathrm{~B} \\
\$ 5.4 \mathrm{~B} \quad(\$ 15 / \mathrm{kgU})\end{array}$ \\
\hline $\begin{array}{l}\text { AGEMCV LLW Disposal: } \\
\text { Conversion to } \mathrm{U}_{3} \mathrm{O}_{3} \\
\text { Disposal Costs } \\
\text { Total Costs }\end{array}$ & $\begin{array}{l}\$ 3.0 \mathrm{~B} \\
\frac{\$ 659 \mathrm{M}}{\$ 3.7 \mathrm{~B}}(\$ 10.25 / \mathrm{kgU})\end{array}$ & ---b--- \\
\hline $\begin{array}{l}\text { RCRA }^{\text {Disposal: }}{ }^{c} \\
\text { Conversion to } \mathrm{U}_{3} \mathrm{O}_{8}{ }^{\mathrm{d}} \\
\text { Disposal Costs } \\
\text { Total Costs }\end{array}$ & $\begin{array}{l}\$ 5.0 \mathrm{~B} \\
\frac{\$ 1.7 \mathrm{~B}}{\$ 6.7 \mathrm{~B}}(\$ 18.56 / \mathrm{kgU})\end{array}$ & $\begin{array}{l}\$ 5.0 \mathrm{~B} \\
\frac{\$ 5.9 \mathrm{~B}}{\$ 10.9 \mathrm{~B}(\$ 30.19 / \mathrm{kgU})}\end{array}$ \\
\hline
\end{tabular}

a. ROM costs only.

b. Retrievable disposal evaluated for NTS only.

c. RCRA disposal included only as a worst-case cost scenario. It is not anticipated that either the $\mathrm{U}_{3} \mathrm{O}_{8}$ or the $\mathrm{CaF}_{2}$ could ever be regulated as a hazardous waste.

d. Conversion costs have been increased by $\$ 2.0 \mathrm{~B}$ to account for added expense associated with a generic RCRA treatment process.

\subsection{Disposal Cost Summaries}

\subsubsection{NTS Disposal}

The total cost estimated for direct LLW disposal of the DU as $\mathrm{U}_{3} \mathrm{O}_{8}$ and the $\mathrm{CaF}_{2}$ at the NTS is $\$ 3.4$ billion $(\$ 9.50 / \mathrm{kgU}$ ) in 1993 dollars (see Table 12). The cost for LLW disposal in an AGEMCV facility at NTS will include the same costs as the direct burial option plus engineering design, construction, and operating costs. Therefore, the total estimated cost for the retrievable disposal option is $\$ 3.4$ billion plus $\$ 256$ million or $\$ 3.7$ billion $(\$ 10.25 / \mathrm{kgU})$. These total and unit costs included the cost of conversion and all related disposal costs as detailed in previous sections.

The ROM cost for RCRA disposal of the $\mathrm{U}_{3} \mathrm{O}_{8}$ and $\mathrm{CaF}_{2}$ based on NTS cost elements total $\$ 6.7$ billion ( $\$ 18.56 / \mathrm{kgU})$, including conversion and a generic treatment process. 


\subsubsection{Hanford Disposal}

For direct LLW disposal at the Hanford site, the cost is $\$ 5.4$ billion ( $\$ 15 / \mathrm{kgU})$ as presented in Table 12. No cost for retrievable disposal is listed since retrieving the $\mathrm{U}_{3} \mathrm{O}_{8}$ from a solidified waste form is assumed for this report to be infeasible. For RCRA disposal at Hanford, the ROM cost estimate is $\$ 10.9$ billion $(\$ 30.19 / \mathrm{kgU})$, including conversion and treatment costs. 


\section{DEPLETED URANIUM DISPOSAL ISSUES}

This chapter briefly summarizes some of the major issues that will need to be examined in greater depth to fully evaluate disposal as a management alternative for DOE's inventory of DU. The following issues have been identified to date as warranting further study:

- Secondary disposal alternatives, such as disposal of $\mathrm{U}_{3} \mathrm{O}_{8}$ in abandoned uranium mines and in existing uranium mill tailings impoundments. and disposal of uranium metal as shielding in high-level waste/spent fuel containers.

- Ongoing negotiations between DOE and Ohio EPA concerning the applicability of hazardous waste regulations to DU.

- $\quad$ Projected demand/uses for DU and the relative merit of maintaining DOE's supply of DU as a potential resource (e.g., retrievable storage/disposal/use) for future projects, such as the breeder reactor program.

- Costs and time frames necessary for establishing domestic capability for converting $\mathrm{UF}_{6}$ to $\mathrm{U}_{3} \mathrm{O}_{8}$. This will impact disposal cost estimates.

- Comparison of disposal options with other DU management alternatives, such as long-term storage as either $\mathrm{U}_{3} \mathrm{O}_{8}$ or $\mathrm{UF}_{6}$, or use as retrievable shielding.

- Elaboration of NTS-specific disposal factors, such as depth of burial, retrievability of directly buried drums, selection of Area 3 or Area 5 as the preferred disposal location, and any future impacts as a result of NTS's ongoing site-specific radiological performance assessments.

- Clearer definition of environmental documentation/permitting needs and their associated costs at NTS based on the above elaboration of NTS-specific disposal factors.

- Feasibility of retrievable disposal in terms of the optimum alternative, disposal packaging, and performance criteria. Cost estimates for retrievable disposal depend on determination of these parameters. As part of this effort, it should be determined whether direct burial of DU drums at the NTS warrants consideration as a retrievable disposal option. 


\section{REFERENCES}

1. T. R. Lemons, et al., The Ultimate Disposition of Depleted Uranium, K/ETO-44. December 1990.

2. Martin Marietta Energy Systems, Inc., Cost Study for the D\&D of the GDPs--Depleted Uranium Management and Conversion, K/D-5940-DF (Draft). September 1991.

3. B. L. Rich, et al., Health Physics Manual of Good Practices for Uranium Facilities, EG\&G Idaho, EGG-2530, 1988.

4. International Commission on Radiological Protection (ICRP), Limits for Intakes of Radionuclides by Workers, ICRP Publication 30, Pergamon Press, New York, 1979.

5. American Conference of Governmental Industrial Hygienists, Threshold Limit Values and Biological Exposure Indices, 1987.

6. Occupational Safety and Health Administration, 29 CFR 1910, Occupational Safety and Health Standards.

7. F. W. Whicker and V. Schultz, Radioecology: Nuclear Energy and the Environment, Volume I, CRC Press, 1980.

8. J. E. Till and H. R. Meyer, Radiological Assessment, U.S. Nuclear Regulatory Commission, NUREG/CR-3332, 1988.

9. Reynolds Electrical \& Engineering Co., Inc., Site Book for Waste Management, December 1991.

10. Oak Ridge National Laboratory Pollutant Assessments Group (Grand Junction, CO), Radiological Performance Assessment, U3ah/at Low-Level Waste Disposal Unit, Nevada Test Site, Revision 1, September 1991.

11. EG\&G Idaho, Inc., Radiological Performance Assessment for the Area 5 Radioactive Waste Management Site at the Nevada Test Site, Revision 1, February 1992.

12. DOE/NV and Reynolds Electrical \& Engineering Co., Inc., Nevada Test Site Defense Waste Acceptance Criteria, Certification, and Transfer Requirements, NVO-325 (Revision 1), June 1992.

13. U.S. DOE, Draft Environmental Impact Statement for the Siting, Construction, and Operation of New Production Reactor Capacity, Volume 2, DOE/EIS-0144D, April 1991.

14. U.S. DOE, Final Environmental Impact Statement, Disposal of Hanford Defense High-Level, Transuranic and Tank Wastes, Volume 1, DOE/EIS-0113, December 1987. 
15. N. P. Willis and G. C. Triner, Hanford Site Solid Waste Acceptance Criteria, WHC-EP-0063-3, September 1991.

16. James M. Taylor, Executive Director for Operations, NRC, Disposition of Depleted Uranium Tails from Enrichment Plants, SECY-91-019, January 25, 1991.

17. George W. Becker, Depleted Uranium Disposition, NMP-91-14 Draft 1. August 26, 1991.

18. National Low-Level Waste Management Program, Directions in Low-Level Waste Management: A Brief History of Commercial Low-Level Radioactive Waste Disposal, DOE/LLW-103, October 1990.

19. G. R. Darnell, et al., Applications of Existing Low-Level Waste Technology Offers 17-to-1 Volume Reduction and Enhanced Disposal at Low Cost, EG\&G Idaho. EGG-LLW-8054, 1988.

20. R. Shuman, et al., Long-Term Structural and Radiological Performance Assessment for an Abovegrade Earth-Mounded Concrete Vault, DOE Defense Low-Level Radioactive Waste Management Program, DOE/LLW-78T. 


\section{APPENDIX A}

COMPARATIVE ECONOMICS OF DISPOSING DU AS U METAL 


\section{APPENDIX A}

\section{COMPARATIVE ECONOMICS OF DISPOSING DU AS U METAL}

As stated in Section 3.2, the preferred chemical form for disposal, used as the reference case in this report, was $\mathrm{U}_{3} \mathrm{O}_{8}$. However, the selection of $\mathrm{U}_{3} \mathrm{O}_{8}$ does not preclude disposal in another form if it can be shown that the environmental, regulatory, and economic factors are more favorable. Therefore, in response to review comments received on the draft report issued in September of 1993, this Appendix has been added to provide an initial economic comparison between disposal of the DU as $\mathrm{U}_{3} \mathrm{O}_{8}$ and as $\mathrm{U}$ metal. Of the alternative forms, DU metal is the most volumetrically efficient form for disposal. Its high density significantly reduces the volume of material, which may provide economic benefits over disposal as an oxide. The regulatory aspects of U metal disposal are more ambiguous; however, the U.S. Army has previously disposed of bulk U metal from their military programs at the Nevada Test Site (NTS). ${ }^{\text {a.b }}$ Based on this precedent, it is assumed that bulk $U$ metal can be an acceptable waste form for disposal. However, it is expected that a site-specific performance assessment will be required to quantify the risk associated with disposal of the very large amounts of $U$ metal that will be generated from the conversion of the current inventory of $\mathrm{UF}_{6}$. Environmentally, $U$ metal oxidizes fairly rapidly into oxides of uranium (e.g., $\mathrm{UO}_{2}$ and $\mathrm{U}_{3} \mathrm{O}_{8}$ ) and is, therefore, in a less stable state than $\mathrm{U}_{3} \mathrm{O}_{8}$ from the onset of disposal. Although the regulatory and environmental aspects are less easily quantified, the basic economics of conversion, packaging, transportation, and burial of the $U$ metal can be estimated based on current data. This Appendix reports these estimated costs.

To parallel the approach taken for disposal of the $\mathrm{DU}$ as $\mathrm{U}_{3} \mathrm{O}_{8}$, the same cost elements are applied to the $U$ metal disposal scenario: (1) costs for conversion of $U_{6}$ to $U$ metal, (2) disposal container cost, (3) transportation costs, (4) environmental/safety documentation and permitting costs, and (5) burial costs for the direct burial of the $U$ metal and secondary waste products. Only LLW disposal at the NTS is considered in this evaluation since the Army established a precedent for acceptance of DU metal at the NTS. The costs are presented for each cost element as total dollars and on a per unit basis (dollars per kilogram uranium) to parallel the costs given in Chapter 6 of this report. Table A1 shows the costs associated with each cost element for DU metal disposal; these costs can be directly compared to Table 10 values established for NTS disposal of $\mathrm{U}_{3} \mathrm{O}_{8}$ (see Chapter 6). A description of how each of these costs were developed follows here.

a. B. Moyer, Aberdeen Proving Ground, personal communication with T. Hertzler, SAIC, March 29, 1994.

b. H. Grewing and J. Frischkorn, Babcock \& Wilcox, personal communications with T. Hertzler, SAIC, March 1994. 
Table A1. Cost Estimates for Low-Level Waste Disposal of DU as U Metal at NTS

\begin{tabular}{|c|c|c|c|c|c|c|}
\hline \multirow[b]{2}{*}{$\begin{array}{l}\text { Waste } \\
\text { Stream }\end{array}$} & \multicolumn{6}{|c|}{ Cost Element } \\
\hline & Conversion & Containers & Transport & Burial & $\begin{array}{c}\text { Environmental } \\
\text { Compliance }\end{array}$ & Total \\
\hline U Metal & $\begin{array}{c}\$ 3.61 \mathrm{~B} \\
\$ 10.00 / \mathrm{kgU}\end{array}$ & $\begin{array}{c}\$ 46.7 \mathrm{M} \\
\$ 0.13 i \mathrm{kgU}\end{array}$ & $\begin{array}{c}\$ 56.1 \mathrm{M} \\
\$ 0.16 / \mathrm{kgU}\end{array}$ & $\begin{array}{c}\$ 15.4 \mathrm{M} \\
\text { S0.04/kgU }\end{array}$ & $\begin{array}{c}\$ 9.0 \mathrm{M} \\
\text { S0.02/kgU }\end{array}$ & $\begin{array}{c}\$ 3.74 \mathrm{~B} \\
\$ 10.35 / \mathrm{kgU}\end{array}$ \\
\hline $\mathrm{MgF}_{2}$ & $--^{a}--$ & $\begin{array}{c}\$ 19.1 \mathrm{M} \\
\$ 0.05 / \mathrm{kgU}\end{array}$ & $\begin{array}{c}\$ 29.1 \mathrm{M} \\
\$ 0.08 / \mathrm{kgU}\end{array}$ & $\begin{array}{c}\$ 28.3 \mathrm{M} \\
\text { S0.08/kgU }\end{array}$ & $--^{2}--$ & $\begin{array}{c}\$ 76.5 \mathrm{M} \\
\$ 0.21 / \mathrm{kgU}\end{array}$ \\
\hline $\begin{array}{l}\text { HF } \\
\text { (credit) }\end{array}$ & $\begin{array}{c}-(\$ 87.0 \mathrm{M})^{\mathrm{c}} \\
-(\$ 0.24 / \mathrm{kgU})\end{array}$ & $-\mathrm{C}^{\mathrm{b}}-$ & -- -- & na & na & $\begin{array}{c}-(\$ 87.0 \mathrm{M}) \\
- \\
(\$ 0.24 / \mathrm{kgU})\end{array}$ \\
\hline Subtotal & $\begin{array}{c}\$ 3.52 \mathrm{~B} \\
\$ 9.76 / \mathrm{kgU}\end{array}$ & $\begin{array}{c}\$ 65.8 \mathrm{M} \\
\$ 0.18 / \mathrm{kgU}\end{array}$ & $\begin{array}{c}\$ 85.2 \mathrm{M} \\
\$ 0.24 / \mathrm{kgU}\end{array}$ & $\begin{array}{c}\$ 43.7 \mathrm{M} \\
\$ 0.12 / \mathrm{kgU}\end{array}$ & $\begin{array}{c}\$ 9.0 \mathrm{M} \\
\$ 0.02 / \mathrm{kgU}\end{array}$ & $\begin{array}{c}\$ 3.73 \mathrm{~B} \\
\$ 10.32 / \mathrm{kgU}\end{array}$ \\
\hline
\end{tabular}

a. Conversion cost applies to U metal only - not waste stream specific.

b. No costs for containers or transport of the HF to Allied Signal included in this evaluation.

c. HF re-sale credit applied to conversion costs.

\section{A.1 Conversion Process and Costs}

\section{A.1.1 Conversion Process and Mass Balance}

The conventional conversion process, commonly known as the "Ames" process, employed for $\mathrm{UF}_{6}$ reduction to $\mathrm{U}$ metal is performed in two steps: the $\mathrm{UF}_{6}$ is converted to $\mathrm{UF}_{\perp}$ (greensalt) using a hydrogen reduction reaction and then the $\mathrm{UF}_{4}$ is converted to $\mathrm{U}$ metal using a batch thermite reduction reaction. ${ }^{c, d}$ The first reduction reaction (Reaction 1 below) is typically performed in a flame tower using pure hydrogen gas $\left(\mathrm{H}_{2}\right)$ as the reactant. The solid $\mathrm{UF}_{6}$ in the existing storage cylinders is heated under pressure to form gaseous $\mathrm{UF}_{6}$. This $\mathrm{UF}_{6}$ gas is fed into the flame tower along with $\mathrm{H}_{2}$. The reduction reaction results in production of an anhydrous hydrogen fluoride (HF) gas and the $\mathrm{UF}_{4}$ product, which is the feed for the second reduction reaction step. The second reduction process involves blending the $\mathrm{UF}_{4}$ with a high grade of chipped magnesium and applying heat to initiate the second reduction reaction (Reaction 2 below). The reaction ignition temperature is nominally $1,080^{\circ} \mathrm{F}$. Once initiated,

c. J. Ellis. Sequoyah Fuels Corporation. personal communication with T. Hertzler, SAIC, April 1993.

d. W. Christian, Aerojet Ordnance Tennessee, personal communication with T. Hertzler, SAIC, May 1993. 
the spontaneous exothermic reaction is sufficient to reduce the reactants to molten uranium metal and magnesium fluoride $\left(\mathrm{MgF}_{2}\right)$. The higher density uranium collects in the bottom of the vessel and the lighter $\mathrm{MgF}_{2}$ accumulates on the top. The uranium metal derby removed from the reaction vessel would be the uranium form expected to be disposed of at the NTS, along with the secondary waste product $\mathrm{MgF}_{2}$.

Reaction 1. $\mathrm{UF}_{6}+\mathrm{H}_{2}=\mathrm{UF}_{4}+2 \mathrm{HF}$

Reaction 2. $\mathrm{UF}_{4}+2 \mathrm{Mg}=\mathrm{U}$ metal $+2 \mathrm{MgF}_{2}$

Based on the Ames process, a stoichiometric mass balance was performed to define the mass relationships between inputs, reactants, intermediates, and products. The resulting mass fractions (i.e., unit mass products per mass of feed) are listed in Table A2.

The most important results from the mass balance are the quantities of anhydrous $\mathrm{HF}, \mathrm{U}$ metal, and $\mathrm{MgF}_{2}$ produced from the $\mathrm{UF}_{6}$ input. Stoichiometrically, for every kilogram of $\mathrm{UF}_{6}$ input into the process $0.114 \mathrm{~kg}$ of $\mathrm{HF}, 0.676 \mathrm{~kg}$ of $\mathrm{U}$ metal, and $0.354 \mathrm{~kg}$ of $\mathrm{MgF}_{2}$ will be produced. Assuming the total inventory of $534,000 \mathrm{MT}^{\circ}$ of $\mathrm{UF}_{6}$ is fed to the conversion process, the resulting quantities of HF, uranium metal, and secondary waste would be $60,800 \mathrm{MT}$, $361,000 \mathrm{MT}$ and 189,000 MT respectively.

\section{A.1.2 Conversion Costs}

\section{Conversion Costs}

Conversion costs have been reported in several preliminary scoping reports and

Table A2. Depleted Uranium Stoichiometric Mass Balance

\begin{tabular}{ccc} 
Input $\mathrm{DU}$ & $\mathrm{As} \mathrm{UF}_{6}, 1$ mass unit & As U metal, 1 m \\
\hline Reactants & & \\
$\mathrm{H}_{2}$ & 0.00574 & 0.00849 \\
$\mathrm{Mg}$ & 0.138 & 0.204 \\
Intermediates & & \\
$\mathrm{UF}_{4}$ & 0.892 & 1.319 \\
$\mathrm{HF}$ & 0.114 & 0.168 \\
Products & & \\
$\mathrm{MgF}_{2}$ & 0.354 & 0.5236 \\
$\mathrm{U}-238$ & 0.676 & 1 \\
(metal) & &
\end{tabular}


presentations on work performed to date in support of the DU recycle program. The conversioncosts reported by vendors and those estimated or obtained from previous conversion activities within DOE varied from a low of $\$ 8.80 / \mathrm{kgU}$ to a high of $\$ 22.00 / \mathrm{kgU}$. ${ }^{1.2 . \text { d.e }}$ Some of these quotes covered both the conversion operations and the disposal of secondary waste materials (i.e.. $\mathrm{MgF}_{2}$ ) in a sanitary landfill. However, as noted above, it is assumed for this assessment that the $\mathrm{MgF}_{2}$ will need to be disposed of in a LLW disposal facility. The higher conversion costs reported were based on uncertainties of specific work requirements, quality of feed materials, and disposal of the byproduct and waste forms. To account for the variability in prices quoted and the uncertainties of actual costs in the future, $\$ 10.00 / \mathrm{kgU}$ is assumed to be the cost of conversion of the $\mathrm{UF}_{6}$ to $\mathrm{U}$ metal without $\mathrm{MgF}_{2}$ waste disposal or re-sale of the anhydrous $\mathrm{HF}$ byproduct. At $\$ 10.00 / \mathrm{kgU}$, the cost to convert the $534,000 \mathrm{MT}$ of $\mathrm{UF}_{6}$ to $361,000 \mathrm{MT}$ of $\mathrm{U}$ metal will be $\$ 3.61$ billion. The disposal costs associated with the $\mathrm{MgF}_{2}$ and credit for HF re-sale are estimated below and factored into the net costs for converting and disposing of the DU reserves within the DOE complex.

\section{A.2 Anhydrous HF Re-Sale}

As indicated above, the intermediate product of the Ames process is anhydrous HF. This $\mathrm{HF}$ is valuable and can be recycled back into production of $\mathrm{UF}_{6}$ from natural uranium ore for feedstock to the gaseous diffusion process. Allied Signal Inc., a primary uranium ore conversion company, currently recycles the anhydrous $\mathrm{HF}$ recovered from existing $\mathrm{UF}_{6}$ to $\mathrm{UF}_{4}$ conversion processes., ${ }^{3, c}$ Re-sale value for this material has been reported to range between $\$ 1.00$ to $\$ 1.43$ per kilogram. ${ }^{3, f}$ The value of $\$ 1.43 / \mathrm{kg}$ HF was used in this evaluation because it has been used in other reports generated for the DOE DU recycle program. However, if container charges and transportation costs for shipping the HF to Allied Signal were not considered in that preliminary evaluation, the total credit resulting from the re-sale of the HF may be considerably less.

HF Recycle Assumptions:

- The mass of $\mathrm{HF}$ generated for re-sale is $60,800 \mathrm{MT}$

- Re-sale value of $\mathrm{HF}$ is $\$ 1.43 / \mathrm{kg} \mathrm{HF}$

- No container or shipping charges to Allied Signal are considered

Based on these assumptions, the credit for anhydrous HF re-sale is $\$ 87,000,000$ or $\$ 0.24 / \mathrm{kg}$ U. Essentially, re-sale of the HF will pay for the costs of disposing of the secondary waste $\mathrm{MgF}_{2}$, as detailed below, with a $\$ 10.5$ million credit allowance remaining.

e. M. Lundberg, Manufacturing Science Corporation, personal communication with T. Hertzler, SAIC, June 1993.

f. B. Quapp, EG\&G Idaho Inc., personal communication with T. Hertzler, SAIC, March 1994. 


\section{A.3 $\quad \mathrm{MgF}_{2}$ Disposal Costs}

Currently, commercial uranium conversion and fabrication facilities (e.g., Aerojet Ordnance Tennessee - AOT) are licensed by the $\mathrm{NRC}$ to dispose of the $\mathrm{MgF}_{2}$ in a sanitary landfill if the residual radioactivity is less than $35 \mathrm{pCi} / \mathrm{g} .{ }^{\mathrm{d}}$ It is not known if the full-scale conversion and fabrication of spent nuclear fuel containers with the subsequent high mass of $\mathrm{MgF}_{2}$ (i.e., 189,000 MT) could still be disposed of in this manner. It is assumed for this Appendix that the large mass of $\mathrm{MgF}_{2}$ would need to be disposed of as LLW instead. This parallels the assumption and cost estimations made for the $\mathrm{CaF}_{2}$ resulting from the conversion of $\mathrm{UF}_{6}$ to $\mathrm{U}_{3} \mathrm{O}_{8}$ in the body of this report.

This material may be disposed of by itself or with the $U$ metal in the void volume around the cylindrical derbies. Preliminary calculations indicate that disposal with the U metal, although initially appearing to be more cost effective, actually may cost slightly more. This is primarily due to the higher unit cost per volume of $\mathrm{MgF}_{2}$ for the containers (i.e., drums vs. metal boxes) and the NTS burial rates charged for drummed $\mathrm{MgF}_{2}$ versus boxed $\mathrm{U}$ metal/MgF (i.e., $\$ 10 / \mathrm{ft}^{3}$ for drummed $\mathrm{MgF}_{2}$ vs. $\$ 15 / \mathrm{ft}^{3}$ for boxed $\mathrm{U}$ metal/MgF $/ \mathrm{F}_{2}$ ). Therefore, the disposal costs shown in Table A1 are based on separate disposal of the $\mathrm{MgF}_{2}$ and $\mathrm{U}$ metal.

The individual costs for containers, transport, and burial were calculated using the same approach as taken in Chapter 6 of this report. Assumptions and data used to estimate the cost for disposing the $\mathrm{MgF}_{2}$ are:

- The mass of $\mathrm{MgF}_{2}$ for disposal is $189,000 \mathrm{MT}$.

. Waste packages are considered to be 208 -liter $17 \mathrm{C}$ metal drums costing $\$ 50.00$ each.

- Transportation to the NTS-

- Is by truck from the point of conversion

- $\quad$ Point of conversion is assumed to be Piketon, $\mathrm{OH}$

- $\quad$ Cost to transport is $\$ 2800.00$ per truckload

- Weight limit per truckload is 42,000 lbs.

- Burial operations at NTS cost $\$ 10 / \mathrm{ft}^{3}$ for the $\mathrm{MgF}_{2}$

- Environmental compliance costs are included in the U metal disposal costs, as shown in Table A1

- As-packaged density of $\mathrm{MgF}_{2}$ is $75 \%$ of theoretical density or $147.0 \mathrm{lbs} / \mathrm{ft}^{3}$

The calculated cost to dispose of the $\mathrm{MgF}_{2}$ at the NTS is $\$ 76,500,000$ or $\$ 0.21 / \mathrm{kgU}$. This cost includes purchase of the drums, transportation to the NTS from Piketon, $\mathrm{OH}$, and burial of the drummed $\mathrm{MgF}_{2}$. Table A1 shows the cost breakdown for each of these cost elements, along with $U$ metal disposal and HF re-sale. 


\section{A.4 DU Metal Disposal Costs}

Currently, the DU metal derby resulting from the Ames process is a right circular cylinder ( $\sim 13$ in. diameter by 12 in. long) weighing approximately 1,000 lbs. ${ }^{g}$ It is assumed that the derbies will be packaged "as is" in approved containers for shipment and burial. Packaging these cylindrical derbies in boxes results in a void volume of approximately $21 \%$; however, the shape of the derby could be modified for better packaging efficiency. ${ }^{\mathrm{g}}$ Due to the density of DU metal, packaging, handling, and transportation are weight controlled rather than volume controlled. Therefore, the cost calculations were performed assuming that the NTS WAC for gross package weight of 9,000 lbs [see Section 5.1.1.2(21)] will control the size of the box and the amount of DU metal per box. This assumption requires that a variance on the size of the waste package be approved by DOE/NV as indicated in Section 5.1.1.2 of this report. No effort was made in this preliminary study to optimize the size/shape/weight of the derby or the disposal package to gain the highest economic benefit for the total system. However, based on the level of accuracy of cost quotes received and assumptions made, the preliminary cost estimates reported here are directly comparable to the uranium oxide disposal costs reported in Chapter 6. The data and assumptions used for the $U$ metal disposal cost estimate are:

- Total mass of $\mathrm{U}$ metal for disposal is $361,000 \mathrm{MT}$

- Containers for DU metal transport and burial are "strong tight" metal boxes approved for LSA material. The boxes are certified for a net DU metal payload of 8,500 lbs and have an approximate disposal volume of $11 \mathrm{ft}^{3}$. The estimated cost per box is $\$ 500^{\mathrm{h}}$

- $\quad$ DOE/NV grants a variance from the standard package size accepted in the NTS WAC [Section 5.1.1.2(20)] for the metal boxes

- Transportation to the NTS-

- $\quad$ Is by truck from the point of conversion

- $\quad$ Point of conversion is assumed to be Piketon, $\mathrm{OH}$

- $\quad$ Cost to transport is $\$ 2800.00$ per truckload

- Weight limit per truckload is $42,000 \mathrm{lbs}$.

- Burial operations at NTS cost $\$ 15 / \mathrm{ft}^{3}$ for the U metal

- Environmental compliance costs are assumed to be $\$ 9 \mathrm{M}(\$ 0.02 / \mathrm{kg} \mathrm{U})$ based on data presented in Chapter 6 of this report.

g. W. Christian, Aerojet Ordnance Tennessee, personal communication with T. Hertzler, SAIC, March 1994.

h. J. King, Container Products Corporations, personal communication with T. Hertzler, SAIC, March 29, 1994. 
The resulting cost for disposing of the $U$ metal, including containers, transportation. burial, and environmental compliance is $\$ 118.2$ million. "The breakdown of these costs is shown in Table A1.

\section{A.5 Conclusions}

Comparing the total costs for disposal of the 361,000 MTU inventory of DU in a metal form versus disposal in an oxide form (i.e., $\mathrm{U}_{3} \mathrm{O}_{8}$ ) [Table $\mathrm{A} 1$ and Table 10, respectively], shows that the cost of disposal as a metal is actually higher. This is due to the higher estimated cost for the initial conversion of $U_{6}$ to $U$ metal $(\$ 10 / \mathrm{kgU})$ versus conversion to $\mathrm{U}_{3} \mathrm{O}_{8}(\$ 8.40 / \mathrm{kgU})$. In both cases, the conversion costs are the most uncertain and/or sensitive to change. The costs associated with containers, packaging, and transportation, although significant, are small in comparison to conversion costs for both disposal alternatives.

The DU metal disposal alternative has a distinct cost advantage over that of the DU oxide alternative in the areas of container, transportation, and burial. However, the estimated conversion cost of $\$ 3.61$ billion negates these advantages.

Finally, the conversion costs for either option may significantly change as additional hard information is obtained and potential new conversion technologies are developed. Currently, two separate research activities are underway that may substantially decrease conversion costs as well as allow for recycle of all intermediate and secondary byproducts, thus eliminating $\mathrm{CaF}_{2}$ or $\mathrm{MgF}_{2}$ disposal. ${ }^{\mathrm{b}, \mathrm{i}}$ Research and development on a Hydrogen Plasma Quench reactor at the INEL and a similar reduction process at the Los Alamos National Laboratory may result in conversion costs four to five times lower than those used in this report.

\section{A.6 References}

1. S. Derrington, Martin Marietta Energy Systems Inc., "DOE Capabilities on Depleted Uranium Conversion and Fabrication," Reuse and Recycle of Depleted Uranium Workshop, October 1993.

2. R. Yoshimura, Sandia National Laboratories, DU Cask Project Cost Analysis Report Outline, Draft Report, September 1993.

3. F. Kosinski, Technics Development Corporation, Review of Commercial Uranium Processing Capability, Draft Report, TDC-100, August 1993.

i. A. Donaldson, et al., $\mathrm{H}_{2}$ Plasma Quench Reactor Research and Development for Reduction of UF 6 Idaho National Engineering Laboratory, in progress, 1994. 